\title{
TWIN RESEARCH AND ENVIRONMENTAL GEOCODING TO UNRAVEL NATURE VS NURTURE
}

\author{
DISSERTATION
}

to obtain the degree of Doctor of Science, Biology by Hasselt University, on the authority of the Rector Prof. dr. L. De Schepper, and the degree of Doctor by Maastricht University, on the authority of the Rector Magnificus Prof. dr. L.L.G. Soete, in accordance with the decision of the Board of Deans, to be defended in public at Maastricht University on Wednesday February 24 2016, at 16.00 hours

by

Esmée Bijnens 


\section{Supervisors}

Prof. Dr T.S. Nawrot (Hasselt University, Belgium)

Prof. Dr M.P. Zeegers (Maastricht University, The Netherlands)

\section{Assessment Committee}

Prof. Dr J.J. van Os (chair; Maastricht University, The Netherlands)

Prof. Dr S. Entringer (Charité University Medicine Berlin, Germany)

Prof. Dr W. Gyselaers (Hasselt University, Belgium)

Prof. Dr H. Peeters (KU Leuven, Belgium)

Prof. Dr C. Thijs (Maastricht University, The Netherlands) 
This research was conducted to investigate the effect of the early-life environment of twins, i.e. residential exposure to air pollution, traffic and greenness, on outcomes at birth and at adulthood. We investigated the exposure at the maternal residential address during pregnancy and its effect on birth weight and biomarkers of ageing in placental tissue, i.e. mitochondrial DNA content and telomere length. Next, we intend to unravel the nature-nurture contribution to these biomarkers of ageing. Twin research provides this opportunity to gain insight in the relative importance of genes and environment. In addition, we also studied the relation between of the early-life environment and blood pressure or telomere length in young adulthood. Both parameters are associated with the development of cardiovascular disease. We hypothesize that an adverse early-life environment will increase the risk of disease later in life.

Although numerous studies have investigated the health effects of air pollution exposure in adults, knowledge on the effects of the early-life environment on birth outcomes, ageing, and disease outcome later in life is limited. The overall hypothesis of this doctoral dissertation is that exposure in the early-life environment of twins affects outcomes both early and later in life.

The specific objectives of this study are:

- To study in utero exposure to air pollution in association with birth weight and small for gestational age in twins (chapter 2).

- To investigate maternal traffic exposure and residential surrounding greenness at the birth address in association with biomarkers of ageing:

- mitochondrial DNA content in placental tissue (chapter 3).

- telomere length in placental tissue (chapter 4).

- telomere length in buccal cells of young adults (chapter 5).

- To estimate the relative importance of genetic and environmental sources of variance of these ageing biomarkers in placental tissue (chapter 3 and 4).

- To assess the effects of residential traffic exposure and surrounding greenness in early and young adult life on ambulatory blood pressure in young adulthood (chapter 6). 
In chapter 2, we examined 4760 twins of the East Flanders Prospective Twin Survey (2002-2013), to study the association between in utero exposure to air pollution with birth weight and small for gestational age. We show that in twins born between 32-36 weeks of gestation, birth weight decreased by $40.2 \mathrm{~g}$ and by $27.3 \mathrm{~g}$ in association with a $10 \mu \mathrm{g} / \mathrm{m}^{3}$ increment in $\mathrm{PM}_{10}$ and $\mathrm{NO}_{2}$ concentration during the third trimester. The corresponding odds ratio for small for gestational age were 1.68 and 1.51 for $\mathrm{PM}_{10}$ or $\mathrm{NO}_{2}$, respectively. No associations between air pollution and birth weight or small for gestational age were observed among term born twins. Assuming causality, an achievement of a $10 \mu \mathrm{g} / \mathrm{m}^{3}$ decrease of particulate air pollution may account for a reduction by $40 \%$ in small for gestational age, in twins born moderate to late preterm.

Among 175 twins, we investigated maternal residential traffic and greenness exposure in association with mitochondrial DNA content in placental tissue of twins in chapter 3 . We showed that placental mitochondrial DNA content is more influenced by environmental factors than genetic factors and is associated with maternal residential greenness and traffic indicators. A doubling in distance to the nearest major road resulted in a decrease in mitochondrial DNA content of $8.32 \%$. An interquartile range increase in residential surrounding greenness in a $100 \mathrm{~m}$ to $5 \mathrm{~km}$ residential radius was associated with a decrease of 5.61 to $10.04 \%$ in mitochondrial DNA content. Higher mitochondrial DNA content might both intensify and/or be a reflection of oxidative stress.

Besides mitochondrial DNA content, we also studied telomere length in chapter 4, an established biomarker of ageing and a general risk factor for age-related chronic diseases. We measured telomere length in placental tissues of 211 twins. Our results show that the variation in telomere length in the placental tissue was mainly determined by the common environment. Furthermore, we observed that maternal residential proximity to traffic and lower residential surrounding greenness is associated with shorter placental telomere length at birth. A doubling in the distance to the nearest major road was associated with a $5.32 \%$ longer placental telomere length at birth. In addition, an interquartile increase $(22 \%)$ in maternal residential surrounding greenness ( $5 \mathrm{~km}$ buffer) was associated with an increase of $3.62 \%$ in placental telomere length. This may 
explain a significant proportion of air pollution-related adverse health outcomes starting from early-life, since shortened telomeres accelerate the progression of many diseases.

Among 205 twins, we show in chapter $\mathbf{5}$ that traffic related exposure in early life is not only associated with shorter telomere length in placental tissue but also in young adulthood. We observed an association between placental telomere length and telomere length in buccal cells in young adulthood. Among twins who were living at a different address than their birth address at time of measurement, adult telomere length and telomere ranking between birth and young adulthood were negatively associated with traffic exposure at the birth address. Whereas, traffic exposure at the residential address at adult age was not associated with telomere length.

In chapter 6, we investigated the effects of residential traffic exposure and residential greenness in the early-life on ambulatory blood pressure in young adulthood. Among twins who were living at a different address than their birth address at time of the measurement $(n=181)$, night-time blood pressure was inversely associated with residential surrounding greenness at adult age as well as with residential greenness in early-life. After additional adjustment for residential greenness exposure in adulthood, an interquartile increase in residential greenness exposure in early-life (5000 m radius) was associated with a $2.42 \mathrm{mmHg}$ decrease in adult night systolic blood pressure. We found no significant effect of adult residential greenness with adult blood pressure, while accounting for the early-life greenness exposure. Our results indicates that residential greenness during the early-life environment has persistent effects on blood pressure.

We observed that prenatal exposure to air pollution and traffic was respectively associated with a suboptimal fetal growth and a change in placental biomarkers of ageing. Besides these outcomes at birth, we noted that exposure to traffic early in life was associated with shorter telomere length in young adulthood and that surrounding greenness in early-life is associated with a lower blood pressure in adulthood. 
Dit onderzoek werd uitgevoerd om de effecten van de vroege leefomgeving van tweelingen na te gaan, zoals onder meer de blootstelling aan luchtvervuiling, verkeer en groene ruimte aanwezig op de woonplaats, op uitkomsten bij de geboorte en op volwassen leeftijd. We onderzochten de effecten van de blootstelling op het residentiële adres van de moeder tijdens de zwangerschap op het geboortegewicht en biomerkers van veroudering in het placentaweefsel, zoals mitochondriale DNA inhoud en telomeerlengte. Vervolgens hebben we getracht om de invloed van genen versus milieu op deze biomerkers van veroudering te ontrafelen. Tweelingonderzoek biedt de mogelijkheid om inzicht te verkrijgen in het relatief belang van genen en milieu. Bovendien bestudeerden we de relatie tussen de vroege leefomgeving en de bloeddruk of telomeerlengte bij jong volwassenen. Beide parameters zijn namelijk geassocieerd met de ontwikkeling van cardiovasculaire ziekten. We veronderstellen dat een nadelige leefomgeving in het vroege leven de kans verhoogt op ziekte in het latere leven.

Hoewel verschillende studies de gezondheidseffecten van luchtvervuiling bij volwassenen al hebben onderzocht is de kennis omtrent de invloed van omgevingsfactoren in het vroege leven op geboorte-uitkomsten, veroudering en ziekte ontwikkeling in het latere leven eerder beperkt. De algemene hypothese van deze dissertatie is dat blootstelling in de vroege leefomgeving van tweelingen een effect heeft zowel vroeg als laat in het leven.

De specifieke objectieven van deze studie zijn:

- Het bestuderen van in utero blootstelling aan luchtvervuiling in associatie met geboortegewicht en de kans om te licht geboren te worden als tweeling (hoofdstuk 2).

- Het onderzoeken van maternale verkeersblootstelling en de aanwezigheid van groene ruimte op het geboorteadres in associatie met merkers van veroudering:

- mitochondriale DNA inhoud in placentaweefsel (hoofdstuk 3)

- telomeerlengte in placentaweefsel (hoofdstuk 4)

- telomeerlengte in wangslijmvlies van jong volwassenen (hoofdstuk 5) 
- Het inschatten van het relatieve belang van genetische en omgevingsbronnen van variatie van deze biomerkers van veroudering in placentaweefsel (hoofdstuk 3 en 4).

- Het beoordelen van de effecten van residentiële verkeersblootstelling en de aanwezigheid van groene ruimte in het vroege- en in het jong volwassen leven op ambulatoire bloeddruk op jong volwassen leeftijd (hoofdstuk 6).

In hoofdstuk 2, onderzochten we 4760 tweelingen van het Oost-Vlaamse meerlingen register (2002-2013), om het verband te bestuderen van in utero blootstelling aan luchtvervuiling in relatie tot geboortegewicht en de kans om te licht geboren te worden. Bij tweelingen die geboren werden tussen 32-36 weken, toonden we aan dat het geboortegewicht daalt met $40.2 \mathrm{~g}$ en met $27.3 \mathrm{~g}$ bij een stijging van $10 \mu \mathrm{g} / \mathrm{m}^{3}$ in $\mathrm{PM}_{10}$ en $\mathrm{NO}_{2}$ concentratie tijdens het derde trimester. De overeenkomende kans om te licht geboren te worden was 1.68 en 1.51 voor $\mathrm{PM}_{10}$ en $\mathrm{NO}_{2}$ respectievelijk. Bij voldragen zwangerschappen werd er geen significante associatie waargenomen tussen luchtvervuiling en geboortegewicht of de kans om te licht geboren te worden. Indien we veronderstellen dat er een oorzakelijk verband is, zou dit betekenen dat indien de concentratie aan fijn stof $\left(\mathrm{PM}_{10}\right)$ zou dalen met $10 \mu \mathrm{g} / \mathrm{m}^{3}$ dit zou leiden tot een vermindering van $40 \%$ in het aantal te licht geborenen bij tweelingen geboren tussen 32-36 weken.

Bij 175 tweelingen onderzochten we maternale residentiële blootstelling aan verkeer en groen in associatie met mitochondriale DNA inhoud in placentaweefsel van tweelingen zoals beschreven in hoofdstuk $\mathbf{3}$. We toonden aan dat mitochondriale DNA inhoud in placentaweefsel meer beïnvloed wordt door omgevingsfactoren dan door genetische factoren en bovendien geassocieerd is met maternale residentiële groene ruimte en verkeersindicatoren. Een verdubbeling in afstand van de woning tot de dichtstbijzijnde belangrijke verkeersweg resulteert in een daling in mitochondriale DNA inhoud van $8.32 \%$. Een stijging in interkwartielafstand in groene ruimte in een straal van $100 \mathrm{~m}$ tot $5 \mathrm{~km}$ van de woonplaats staat in verband met een daling van $5.61 \%$ tot $10.04 \%$ in mitochondriale DNA inhoud. 
Meer mitochondriale DNA inhoud zou mogelijk oxidatieve stress versterken en/of een reflectie zijn van oxidatieve stress.

Naast mitochondriale DNA inhoud, bestudeerden we ook telomeerlengte in hoofdstuk 4, een biomerker van veroudering en een algemene risicofactor voor chronische ziekten die gepaard gaan met veroudering. Telomeerlengte werd gemeten in placentaweefsel van 211 tweelingen. Onze resultaten tonen aan dat de variatie in telomeerlengte in placentaweefsel vooral bepaald wordt door de gemeenschappelijke omgeving. Bovendien namen we waar dat maternale residentiële nabijheid tot verkeer en een verminderde groene ruimte in de omgeving geassocieerd is met een kortere telomeerlengte in placentaweefsel bij de geboorte. Een verdubbeling in afstand tot de dichtstbijzijnde belangrijke verkeersweg staat in verband met $5.32 \%$ langere telomeerlengte bij de geboorte. Daarnaast namen we waar dat een stijging van een interkwartielafstand $(22 \%)$ in groene ruimte in de omgeving van de woning van de moeder (5 $\mathrm{km}$ straal) in verband staat met een $3.62 \%$ langere telomeerlengte in placentaweefsel. Dit zou mogelijk een deel kunnen verklaren van de nadelige luchtvervuilingsgerelateerde gezondheidsuitkomsten die al starten in het vroege leven aangezien verkorte telomeren de progressie van verschillende ziekten kan versnellen.

Bij 205 tweelingen toonden we in hoofdstuk 5 aan dat de blootstelling aan verkeer in het vroege leven niet enkel geassocieerd is met een kortere telomeerlengte in placentaweefsel maar ook in wangslijmvlies afgenomen op jong volwassen leeftijd. We hebben waargenomen dat telomeerlengte op deze twee verschillende tijdspunten in verband staat met elkaar. Bij tweelingen waarvan het adres op volwassen leeftijd verschillend was van hun geboorteadres, vonden we dat de telomeerlengte op volwassen leeftijd maar ook de rangschikking van telomeerlengte tussen geboorte en jong volwassenheid negatief geassocieerd waren met verkeersblootstelling op het geboorte adres. Terwijl verkeersblootstelling op volwassen leeftijd niet geassocieerd was met telomeerlengte.

In hoofdstuk $\mathbf{6}$ onderzochten we de effecten van residentiële verkeersblootstelling en groene ruimte in de woonomgeving in het vroege leven viii 
op ambulatoire bloeddruk op jong volwassen leeftijd. Bij tweelingen waarvan het adres op het tijdstip van de meeting verschillend was van hun geboorteadres $(n=181)$, hebben we een inverse associatie waargenomen tussen bloeddruk tijdens de nacht en zowel groene ruimte in de woonomgeving in het volwassen als in het vroege leven. $\mathrm{Na}$ een bijkomende aanpassing voor groene ruimte in de woonomgeving in het volwassen leven, stond een stijging in interkwartielafstand in residentiële blootstelling aan groene ruimte in het vroege leven ( $5 \mathrm{~km}$ straal) in verband met een $2.25 \mathrm{mmHg}$ daling in systolische bloeddruk tijdens de nacht in het volwassen leven. We vonden geen significant effect van groene ruimte in de woonomgeving op volwassen leeftijd met bloeddruk op volwassen leeftijd indien we rekening hielden met de blootstelling aan groene ruimte in het vroege leven. Onze resultaten tonen aan dat residentiële groene ruimte in het vroege leven een blijvend effect heeft op bloeddruk.

We observeerden dat prenatale blootstelling aan luchtvervuiling en verkeer respectievelijk in verband staat met een suboptimale fetale groei en een verandering in placentale biomerkers van veroudering. Naast deze uitkomsten bij de geboorte, merkten we op dat blootstelling aan verkeer in het vroege leven geassocieerd is met een kortere telomeerlengte op jong volwassen leeftijd en de groen in de woonomgeving vroeg in het leven geassocieerd is met een lagere bloeddruk in het volwassen leven. 
Table of contents 


\section{TABLE OF CONTENTS}

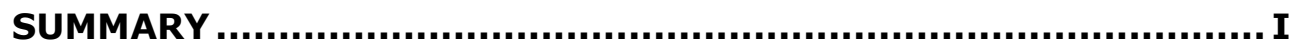

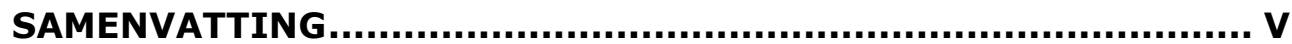

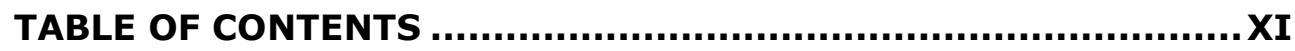

CHAPTER 1. GENERAL INTRODUCTION ..................................1

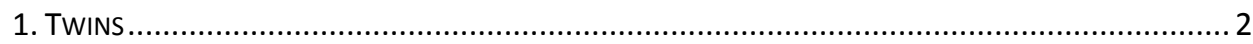

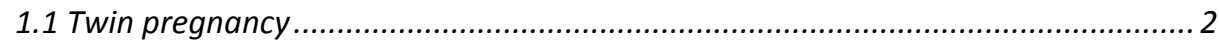

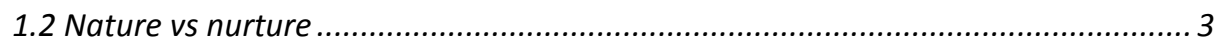

1.3 The East Flanders Prospective Twin Survey (EFPTS) ........................................... 4

1.4 Prenatal Programming Twin Study (PPTS) ....................................................... 5

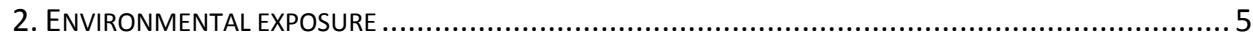

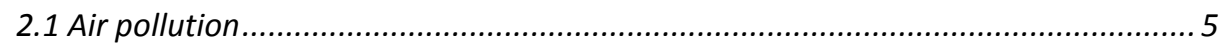

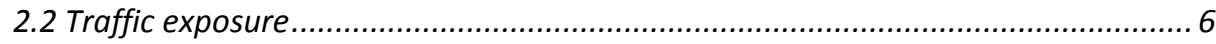

2.3 Greenness.............................................................................................. 7

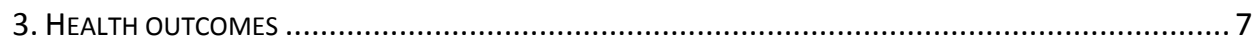

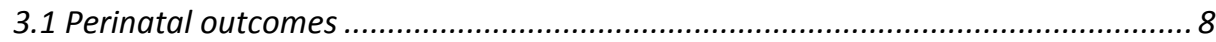

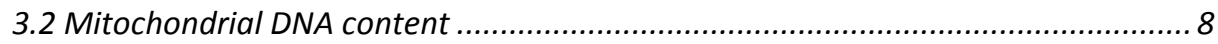

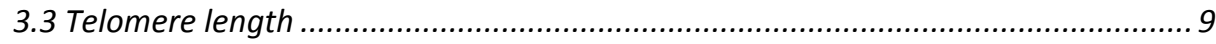

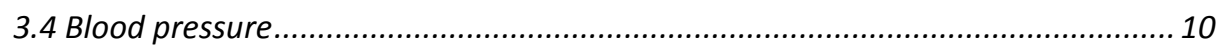

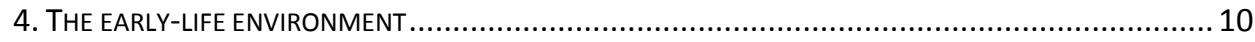

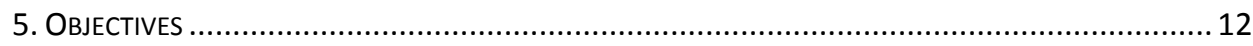

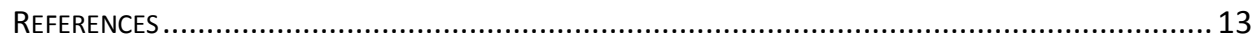

CHAPTER 2. SMALL FOR GESTATIONAL AGE AND EXPOSURE TO PARTICULATE AIR POLLUTION IN THE EARLY-LIFE ENVIRONMENT OF TWINS ......................................................19

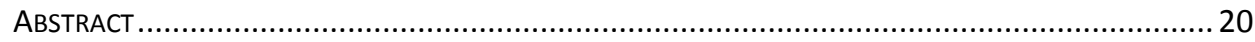

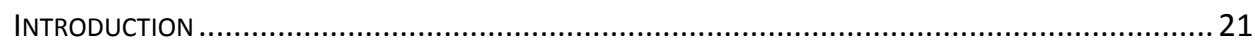

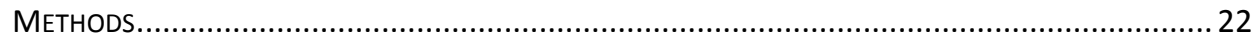


RESULTS

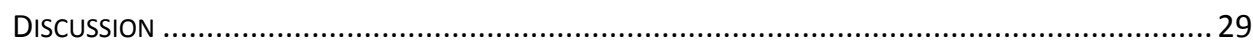

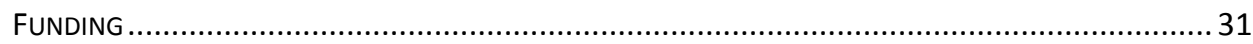

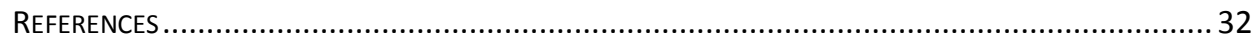

CHAPTER 3. PLACENTAL MITOCHONDRIAL DNA CONTENT IS

ASSOCIATED WITH MATERNAL RESIDENTIAL TRAFFIC AND

GREENNESS: A TWIN STUDY..................................................35

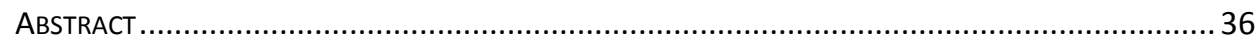

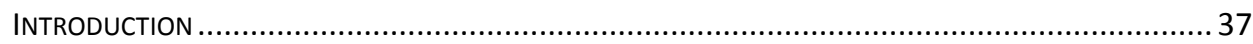

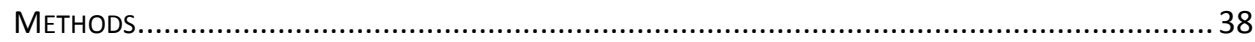

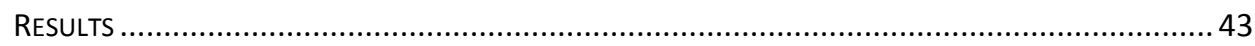

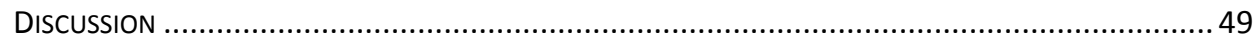

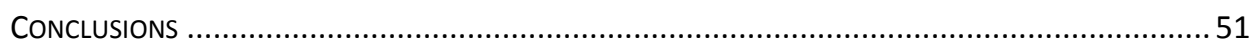

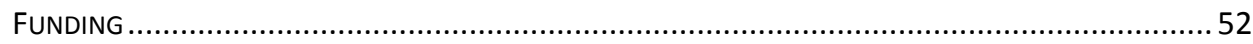

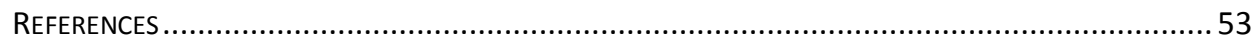

CHAPTER 4. LOWER PLACENTAL TELOMERE LENGTH MAY BE ATTRIBUTED TO MATERNAL RESIDENTIAL TRAFFIC EXPOSURE; A

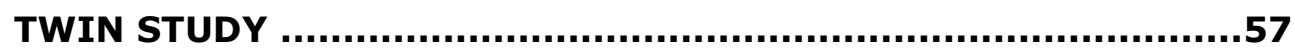

ABSTRACT 
CHAPTER 5. TELOMERE TRACKING ACROSS THE THREE FIRST DECADES OF LIFE AND RESIDENTIAL TRAFFIC AND GREENNESS

EXPOSURE 81

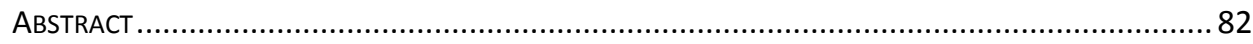

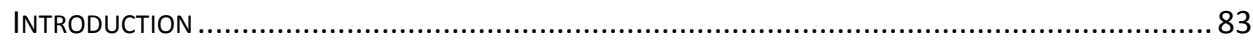

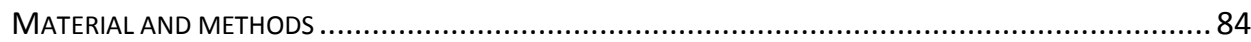

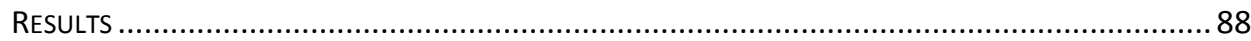

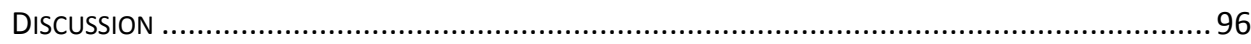

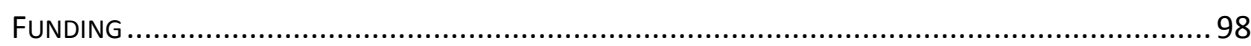

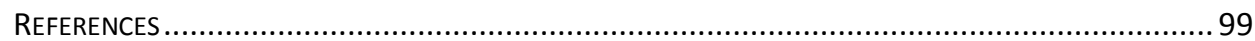

CHAPTER 6. BLOOD PRESSURE IN YOUNG ADULTHOOD AND

RESIDENTIAL EXPOSURE OF TRAFFIC AND GREENNESS IN THE

EARLY LIFE ENVIRONMENT OF TWINS ..................................105

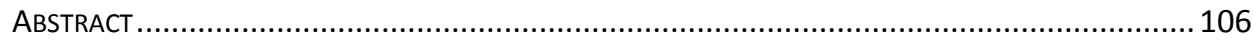

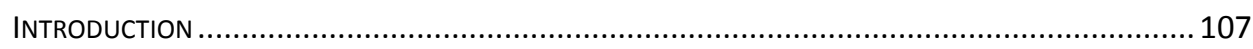

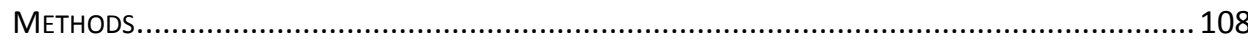

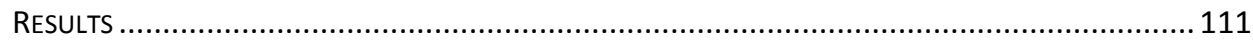

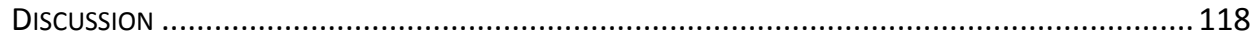

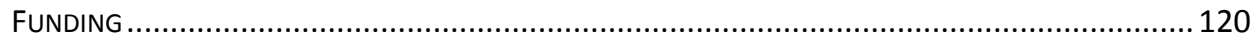

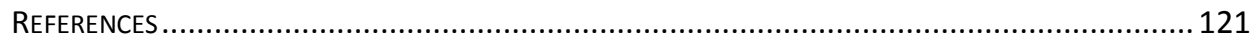

CHAPTER 7. GENERAL DISCUSSION ..................................127

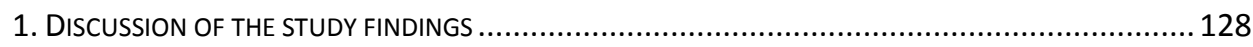

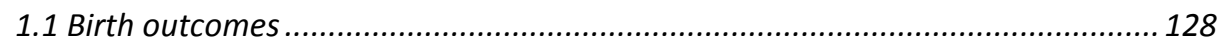

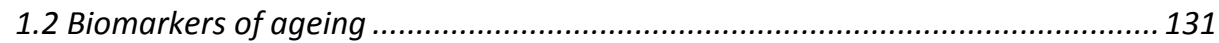

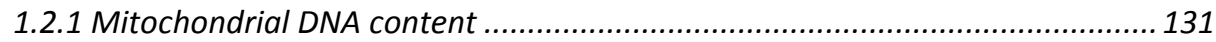

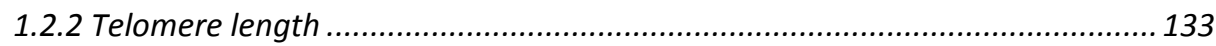

1.3 Greenness in early-life and blood pressure in young adulthood ......................... 136

2. EARLY-LIFE EXPOSURE AND DISEASE OUTCOME LATER IN LIFE .............................................. 138

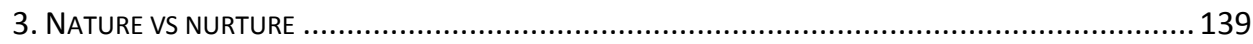




\section{APPENDICES........................................................................... 145}

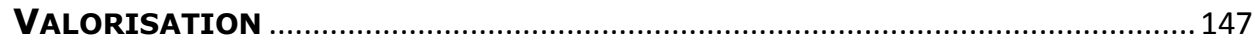

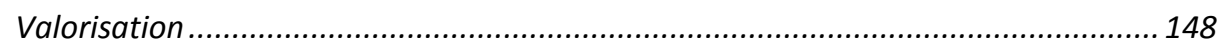

Economic cost of air pollution in Europe ........................................................... 148

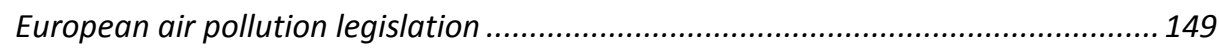

Health implications of exposure in the early-life environment ............................... 151

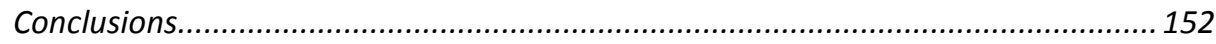

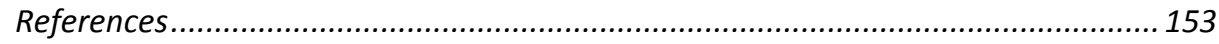

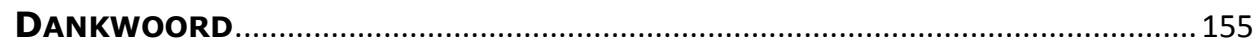

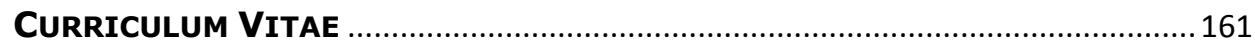

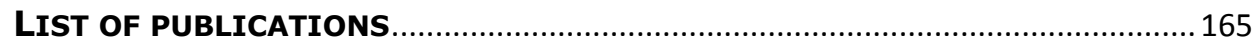

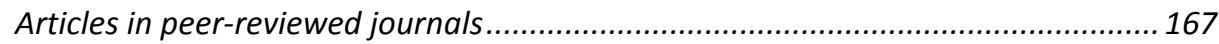

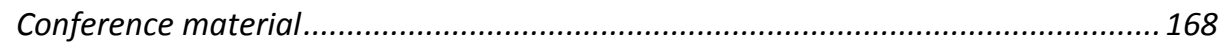


CHAPTER 1

General Introduction 
This research was conducted to investigate the effect of the early-life environment of twins, i.e. residential exposure to air pollution, traffic and greenness, on outcomes at birth and at adulthood. Twins can provide the opportunity to the contribution of unravel genes vs environment. We hypothesize that an adverse early-life environment will increase the risk of disease later in life. Possible underlying mechanisms include suboptimal fetal growth and dysregulation of cellular ageing. Therefore we estimated the exposure at the maternal residential address during pregnancy and its effect on birth weight and biomarkers of ageing in placental tissue, i.e. mitochondrial DNA content and telomere length. In addition, we also studied in young adults the relation between of their early-life environment and blood pressure or telomere length. Both parameters are associated with the development of cardiovascular disease.

\section{TWINS}

\subsection{Twin pregnancy}

In Belgium, about $1.8 \%$ of all pregnancies in 2013 were twin pregnancies. ${ }^{1}$ Since the mid-1980's the number of multiple births have increased, because of increased ovulation stimulating agents and other assisted reproduction techniques. ${ }^{2,3}$ Just over half (55.9\%) of multiple births in Flanders have low birth weight (less than $2500 \mathrm{gram}$ ) and $57.8 \%$ of the twins are born before 37 weeks of gestation and are defined as preterm. ${ }^{1}$ The growth of a twin fetus differs from a singleton after 32 weeks of gestation probably due to the restricted capability of the uterine environment to nurture more than one fetus at a time (Figure 1.1.). ${ }^{4-6}$ This results not only in decreased birth weight but also increased odds of perinatal morbidity and mortality. ${ }^{7}$ 


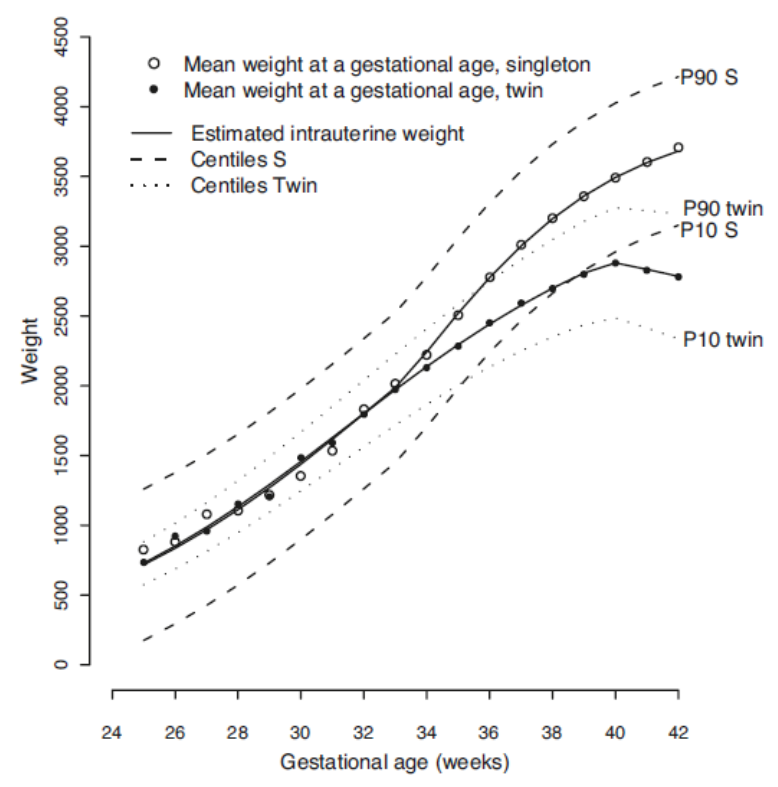

Figure 1.1. Growth curves based on birth weights of singletons $(n=76,471)$ and twins $(n=$ 8,454; pairs $=4,227$ ) born in East-Flanders (Belgium) between 1964 and 2003 . P90 $=90^{\text {th }}$ centile, $\mathrm{P} 10=10^{\text {th }}$ centile, $\mathrm{S}=$ Singletons (Gielen et al., 2008). ${ }^{6}$

\subsection{Nature vs nurture}

Twin research provides the opportunity to gain insight in the relative importance of genes and environment or nature vs nurture aspects. Dizygotic or fraternal twins are developed from two different eggs and share about half of their genes. Monozygotic twins result from the division of one embryo and are generally genetically identical. The division takes place during the first 14 days following fertilization and the moment of separation can be deduced from a visual examination of the membranes (Figure 1.2.). Early separation (first $72 \mathrm{~h}$ postfertilization) results in dichorionic-diamniotic twins, later separation (before day 8) are monochorionic-diamniotic twins, rare separation (after 8 days up to 12 days) are monochorionic-monoamniotic. If the divisions occurs later (12-13 days after fertilisation) this will result in conjoined twins. The classic twins study can unravel nature vs nurture by comparing the intrapair similarity of monozygotic twins with dizygotic twins. Differences between members of a dizygotic twins pair can be the result of genetic or environmental factors, while in a 
monozygotic twin pair differences can only be the result of environmental factors. Assuming that monozygotic and dizygotic twins share their common environment to the same extent, an observation of a greater within-pair similarity in monozygotic (MZ) twins than in dizygotic (DZ) twins reflects genetic influences.

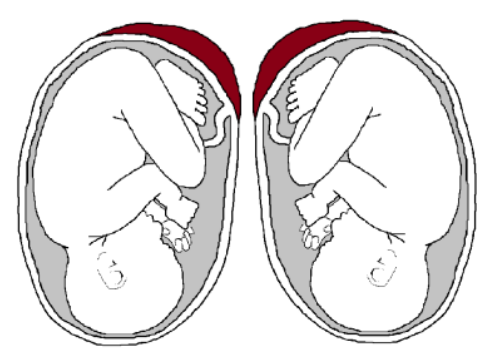

Dichorionic-Diamniotic

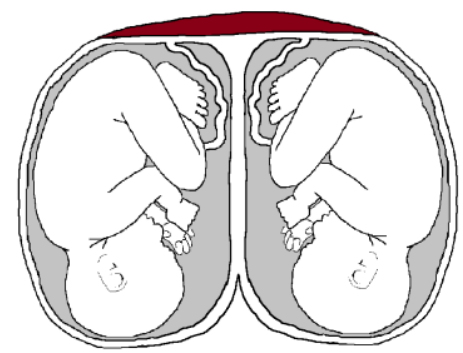

Monochorionic-Diamniotic

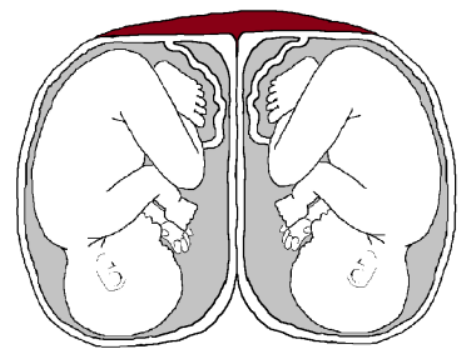

Dichorionic-Diamniotic

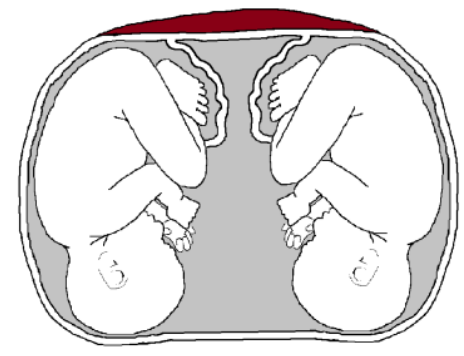

Monochorionic-Monoamniotic

Figure 1.2. Chorionicity and amnionicity in twin pregnancies.

\subsection{The East Flanders Prospective Twin Survey (EFPTS)}

The East Flanders Prospective Twin Survey (EFPTS) is one of the world's largest longitudinal prospective twin cohort with more than 9000 twin pairs. This population register was started in July 1964 at Ghent University at the Department of Obstetrics by Robert Derom and Michel Thiery. At present it is hosted by 'Twins', a non-profit association for scientific research in multiple births, and is now partly funded by the department of Human Genetics of the University of Leuven (Belgium), 'Twins', and the University of Maastricht (The Netherlands). ${ }^{2}$ The register is characterized by the systematic examination of the placenta, accurate determination of zygosity and chorionicity. Zygosity is determined by sequential analysis based on sex, chorion type, umbilical cord 4 
blood groups, placental alkaline phosphatise, and since 1982 also DNA fingerprints. ${ }^{8}$ This results in a zygosity probability of 0.999 .

\subsection{Prenatal Programming Twin Study (PPTS)}

A subset of the twins from the EFPTS (424 pairs) aged 18 to 34 years participated in the Prenatal Programming Twin Study (PPTS). Details of the selection process have been described previously. ${ }^{9}$ Between February 1997 and April 2001 anthropometric and ambulatory blood pressure measurements were performed. Biological samples, such as fasting blood samples, $24 \mathrm{~h}$ urine, and buccal swabs were collected. This protocol provides the opportunity to follow up twins from birth to adulthood and to investigate the effect of traffic related air pollution exposure in early-life on outcomes both early and later in life.

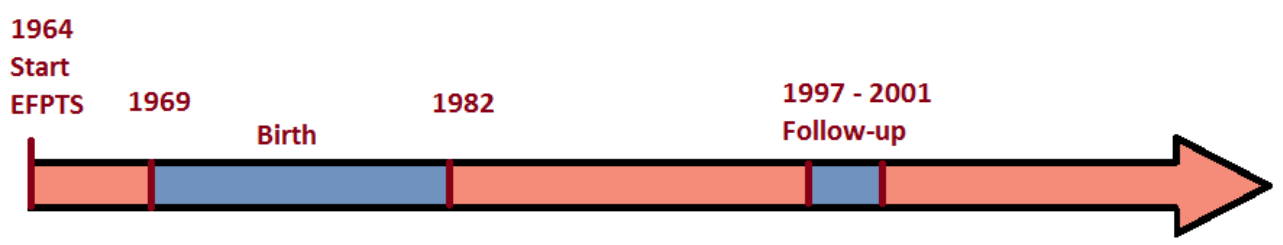

Figure 1.3. Timeline Prenatal Programming Twin Study. The twins are born between 1969 and 1982 and joint a follow-up study between February 1997 and April 2001.

\section{ENVIRONMENTAL EXPOSURE}

\subsection{Air pollution}

Two important categories of air pollution sources are natural phenomena and human activities. The latter, also know also anthropogenic sources, produce carbon monoxide ( $\mathrm{CO}$ ) and nitrogen oxides $\left(\mathrm{NO}_{\mathrm{x}}\right)$ from vehicle exhausts or sulphur dioxide $\left(\mathrm{SO}_{2}\right)$ from industrial processes. After emission into the atmosphere, chemical reactions can transform these primary pollutants into secondary pollutants, e.g. ozone $\left(\mathrm{O}_{3}\right)$, carbon dioxide $\left(\mathrm{CO}_{2}\right)$ and nitrogen dioxide $\left(\mathrm{NO}_{2}\right) \cdot{ }^{10}$ 
Besides this complex mixture of gaseous substances, the atmosphere also contains particulate matter (PM), consisting of a mixture of solid and liquid particles. Anthropogenic sources of PM are solid-fuel combustion (coal, lignite, heavy oil and biomass), industrial activities, erosion of the pavement by road traffic, and abrasion of brakes and tires. ${ }^{11} \mathrm{PM}$ is categorised on the basis of its aerodynamic diameter (Fig 1.4.).
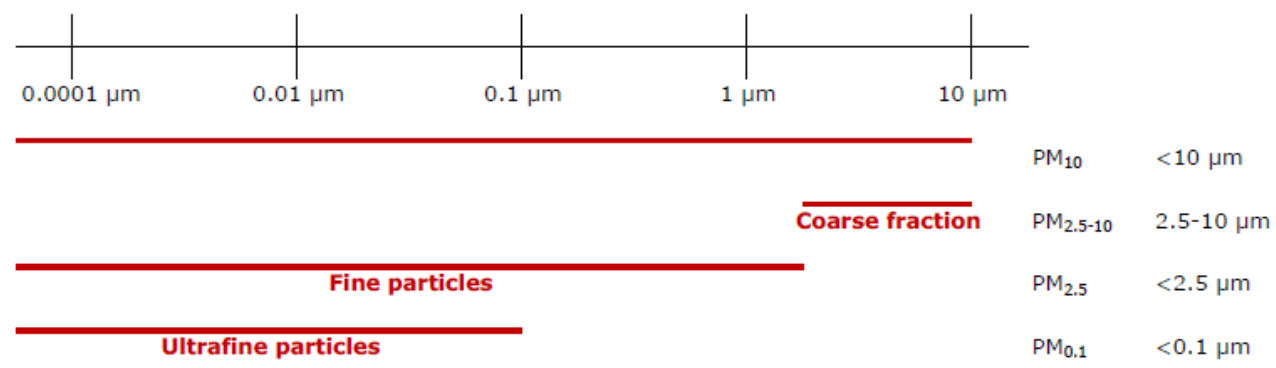

Figure 1.4. Categorisation of particle matter based on its aerodynamic diameter; $\mathrm{PM}_{10}<10 \mu \mathrm{m}, \mathrm{PM}_{2.5}<2.5 \mu \mathrm{m}$ and ultrafine particles $\left(\mathrm{PM}_{0.1}\right)<0.1 \mu \mathrm{m}$.

PM can contain toxic substances and transport these into the respiratory tract. Coarse particles are deposited in the nasal cavities and upper airways whereas fine particles may penetrate the lung alveoli. In the lungs phagocytosis of particles by alveolar macrophages results in oxidative stress and inflammation. ${ }^{12}$ The ultrafine particles can translocate into the blood circulation (Fig 1.5.). ${ }^{13}$

\subsection{Traffic exposure}

Road traffic contributes largely to airborne PM pollution. Sources of PM emissions from road vehicles include besides engine exhaust also abrasion of tyres, road surface and brake components. Non-exhaust emission contribute mainly to $\mathrm{PM}_{10}$, while exhaust emissions contribute predominantly to $\mathrm{PM}_{2.5} \cdot{ }^{14}$ Two broad categories to estimate traffic exposure have been used in epidemiological studies. The first category is measured or modelled pollutant concentrations of traffic surrogates, of which the most commonly used are $\mathrm{CO}$, $\mathrm{NO}_{2}$, elemental carbon, benzene, and particulate matter. The second category is direct measurements of traffic with a geographic information system. Indicators 
of traffic exposure are distance of the residence to the nearest road and traffic density within a specific radius from the residence.

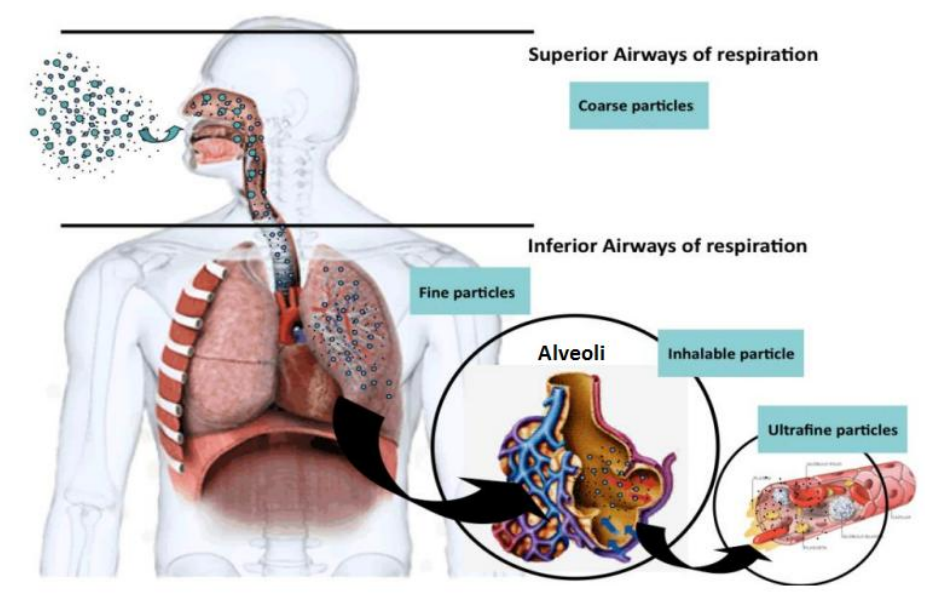

Figure 1.5. The deposition of PM particles is dependent on its aerodynamic diameter (adapted from Guarieiro et al., 2013). ${ }^{15}$

\subsection{Greenness}

Greenness or green space is an aggregation of natural environments classified as such based on land cover data, such as the European CORINE data or based on satellite imagery, such as Normalised Difference Vegetation Index (NDVI). ${ }^{16}$ Many studies suggest that exposure to greenness enhances human health. ${ }^{17}$ Greenness may influence health by promoting physical activity and social contact, decreasing stress, and mitigating heat, noise, and air pollution exposure. ${ }^{17}$

\section{HEALTH OUTCOMES}

Ambient air pollution is considered a global public health threat ${ }^{18-20}$ and is, according to the World Health Organization (WHO), responsible for approximately 3.7 million premature deaths worldwide in $2012 .^{21}$ Exposure to particulate matter is associated with respiratory diseases, such as asthma ${ }^{22}$ and chronic obstructive pulmonary disease (COPD), ${ }^{23}$ and can even adversely affect 
lung development in children. ${ }^{24}$ Besides these pulmonary diseases particulate matter is also associated with cardiovascular morbidity and mortality. Clinical manifestations of cardiovascular disease, include myocardial infarction, stroke, heart failure, arrhythmias, and venous thromboembolism. ${ }^{25-27}$

\subsection{Perinatal outcomes}

Birth outcomes are a category of measures that describe health at birth. We will focus on two endpoints; birth weight (BW) and small for gestational age (SGA). Births are classified as low birth weight if birth weight is below $2500 \mathrm{~g}$ and as small for gestational age when birth weight was below the $10^{\text {th }}$ percentile of the birth weight for a given gestational age and sex. Low birth weight and small for gestational age are associated with increased neonatal morbidity and mortality. ${ }^{28,29}$

Several studies have shown that maternal exposure to ambient air pollutants during pregnancy is associated with restricted fetal growth. ${ }^{30-33}$ Moreover, evidence suggest that the health impact of prenatal $\mathrm{PM}$ and $\mathrm{NO}_{2}$ exposure continues into infancy, resulting in wheezing, respiratory infections ${ }^{34}$ entailing alterations in the development of an infant's immune system, which may increase the risk of asthma and allergies. ${ }^{35}$ Moreover, traffic-related air pollution is also associated with adverse birth outcomes. ${ }^{36-38}$ Residential proximity to freeways during pregnancy increases not only the risk of respiratory infections during the first year of life ${ }^{39}$ but can even increase the risk of neurodevelopment disorders such as autism. ${ }^{40}$ Contrary to air pollution, residential greenness is associated with beneficial birth outcomes, e.g. higher term birth weight, reduction of preterm births and SGA. ${ }^{41}$ These associations remain even after adjusting for air pollution and noise exposure. ${ }^{41}$ In addition, more residential surrounding greenness during pregnancy is associated with larger head circumferences, ${ }^{42}$ and lower infant mortality risk. ${ }^{43}$

\subsection{Mitochondrial DNA content}

Mitochondria play an important role in cellular processes including ATP production, apoptosis, cellular redox homeostasis, signalling transduction and 
stress responses. ${ }^{44}$ Changes in mitochondrial DNA content have been reported in a variety of human diseases such as cancer, human immunodeficiency virus (HIV) and metabolic disorders such as diabetes and obesity. ${ }^{45}$ Air pollution exposure is an important environmental source of oxidative stress and can result in changes in mitochondrial DNA content. ${ }^{46-49}$ Mitochondrial DNA is more vulnerable for oxidative damage than nuclear DNA due the lack of protective histones and a less efficient DNA repair system. ${ }^{50}$ Therefore, oxidative stress will lead to accumulation of mutations and damage to mitochondrial DNA. Persistent stress can even alter the rate of mitochondrial DNA replication and result in a decline in mitochondrial respiratory function. To compensate for this decline, oxidative stress will increases mitochondrial abundance and mitochondrial DNA content. A disadvantage is that an increase in mitochondria causes excess ROS generation and further oxidative damage. This could accelerate the ageing process or cell death. ${ }^{51}$

\subsection{Telomere length}

Telomeres are located at the end of the chromosomes and consist of TTAGGG tandem repeats. ${ }^{52}$ Due to the end-replication problem telomeres progressively shorten in somatic cells and mean telomere length is observed to diminish with age. ${ }^{53}$ In embryonic stem cells and germline cells, telomere length is maintained by telomerase, a ribonucleoprotein that extend telomeres. ${ }^{54}$ Telomere length is proposed as a marker of the biological ageing process ${ }^{55}$ and as a general risk factor for age-related chronic diseases, such as cancer, ${ }^{56,57}$ type 2 diabetes, ${ }^{58}$ and cardiovascular disease. ${ }^{59}$ In addition, studies in elderly twins even show an association between telomere length and mortality. ${ }^{60,61}$ Although telomere length diminishes with age, variation in telomere length between persons of the same chronological age exists and this appears to be as wide as the variation in newborns. ${ }^{62}$ This variation may be the result of both genetic and environmental factors. ${ }^{63}$ In adults, long-term exposure to traffic has been linked to shorter telomeres. ${ }^{64,65}$ It is even suggested that telomere length may be part of the underlying mechanism between air pollution and cardiovascular disease since oxidative stress may accelerate telomere erosion. ${ }^{66}$ Telomeres are highly sensitive to oxidative stress, due to their high guanine content and the deficient repair system of single-strand breaks. ${ }^{67}$ 


\subsection{Blood pressure}

High blood pressure is the leading risk factor for cardiovascular disease and mortality in the world. 68,69 Monitoring of ambulatory blood pressure with multiple measurements recorded during usual daily activities is even a better predictor of risk of all-cause and cardiovascular mortality than medical office blood pressure measurements. ${ }^{70}$ Many risk factors underlying hypertension have been identified including nonmodifiable factors such as age, gender, race, and genetics, as well as modifiable factors including high BMI, high sodium intake, low potassium intake, alcohol consumption, and reduced physical activity. ${ }^{71}$ Besides these well-established factors also environmental factors can influence blood pressure. Residential PM and traffic exposure are associated with increased arterial blood pressure and elevated prevalence of hypertension. ${ }^{72,73}$ In addition, also areas with lower greenness have higher levels of stroke mortality ${ }^{74}$ and cardiovascular disease mortality. ${ }^{75,76}$ Independent of air pollution, higher residential greenness is associated with lower blood pressure in children. $^{77}$

\section{THE EARLY-LIFE ENVIRONMENT}

In classic epidemiology, complex cardiovascular and metabolic diseases of middle and old age have been considered the result of interaction between the adulthood lifestyle and genetic predisposition to disease. The last decades, the importance of the early-life environment in disease development has been increasingly recognized. ${ }^{78}$ The early-life environment begins before conception, spans across pregnancy, and continues into the postnatal period. The Developmental Origins of Health and Disease (DOHaD) hypothesis, often called the 'Barker hypothesis' after one of its leading proponents, states that adverse influences of the early-life environment can result in permanent changes in physiology and metabolism, which result in increased disease risk in adulthood. ${ }^{79}$ Barker's work showed an association between low birth weight and several cardiovascular diseases (including ischemic heart disease), hypertension, cholesterol levels, stroke, and diabetes. ${ }^{80-86}$ 
Barker and colleagues hypothesized that most organs and systems have specific periods of growth in utero. During these critical periods the system is plastic and sensitive to the environment, after this period the adaptation is irreversible. Insults during this sensitive period of development can have an lasting influence. This enables the production of phenotypes that are better matched to their environment. However, when the intrauterine and the extrauterine environment differ, this can cause a relative overcompensation making the offspring more susceptible for disease when they become adult. ${ }^{87}$ For instance, data from the Dutch famine at the end of world war II shows that maternal nutrition deprivation during the first half of pregnancy resulted in significantly higher obesity rates in adulthood. ${ }^{88}$

Birth weight depends not only on the mother's nutrition but also on placental functioning. Maternal air pollution exposure may affect birth weight by inducing oxidative stress and inflammation, ${ }^{27}$ which could affect placental growth and function, ${ }^{89}$ and subsequently resulting in fetal growth restriction. According to the Developmental Origins of Health and Disease hypothesis, children with low birth weight are not only at risk for perinatal morbidity and mortality but they also have an increased risk for developing ill health conditions later in life. 


\section{OBJECTIVES}

Although numerous studies have investigated the health effects of air pollution exposure in adults, knowledge on the effects of the early-life environment on birth outcomes, ageing, and disease outcome later in life is limited. The overall hypothesis of this doctoral dissertation is that exposure in the early-life environment of twins affects health outcomes both early and later in life.

The specific objectives of this study are:

- To study in utero exposure to air pollution in association with birth weight and small for gestational age in twins (chapter 2).

- To investigate maternal traffic exposure and residential surrounding greenness at the birth address in association with biomarkers of ageing:

- mitochondrial DNA content in placental tissue (chapter 3).

- telomere length in placental tissue (chapter 4).

- telomere length in buccal cells of young adults (chapter 5).

- To estimate the relative importance of genetic and environmental sources of variance of these ageing biomarkers in placental tissue (chapter 3 and 4).

- To assess the effects of residential traffic exposure and surrounding greenness in early and young adult life on ambulatory blood pressure in young adulthood (chapter 6 ). 


\section{REFERENCES}

1. Cammu HM, E.; Martens, G.; Van Mol, C.; Jacquemyn Y. Perinatale activiteiten in Vlaanderen 2013. 2014.

2. Derom C, Thiery E, Peeters $H$, Vlietinck R, Defoort $P$ and Frijns JP. The East Flanders Prospective Twin Survey (EFPTS): an actual perception. Twin research and human genetics: the official journal of the International Society for Twin Studies. 2013;16:58-63.

3. Derom C, Vlietinck R, Derom R, Van den Berghe $\mathrm{H}$ and Thiery $\mathrm{M}$. Increased monozygotic twinning rate after ovulation induction. Lancet. 1987;1:1236-8.

4. Blickstein I. Intrauterine Growth. In: L. Keith, ed. Multiple pregnanciy: epidemiology, gestation \& perinatal outcome New York: The Parthenon Publishing Group; 1995: 503-513.

5. Doom EC, Delbaere I, Martens G and Temmerman M. Birth weight for gestational age among Flemish twin population. Facts Views Vis Obgyn. 2012;4:42-9.

6. Gielen M, Lindsey PJ, Derom C, Loos RJ, Souren NY, Paulussen AD, et al. Twin-specific intrauterine 'growth' charts based on cross-sectional birthweight data. Twin research and human genetics : the official journal of the International Society for Twin Studies. 2008;11:224-35.

7. Hack KE, Derks JB, Elias SG, Franx A, Roos EJ, Voerman SK, et al. Increased perinatal mortality and morbidity in monochorionic versus dichorionic twin pregnancies: clinical implications of a large Dutch cohort study. BJOG : an international journal of obstetrics and gynaecology. 2008;115:58-67.

8. Vlietinck R. Determination of the zygosity of twins Leuven: Katholieke Universiteit Leuven; 1986: 1-123.

9. Loos RJ, Beunen G, Fagard R, Derom C and Vlietinck R. The influence of zygosity and chorion type on fat distribution in young adult twins consequences for twin studies. Twin Res. 2001;4:356-364.

10. Lee BJ, Kim B and Lee K. Air pollution exposure and cardiovascular disease. Toxicol Res. 2014;30:71-5.

11. Srimuruganandam B and Shiva Nagendra SM. Source characterization of PM10 and PM2.5 mass using a chemical mass balance model at urban roadside. Sci Total Environ. 2012;433:8-19.

12. Sijan Z, Antkiewicz DS, Heo J, Kado NY, Schauer JJ, Sioutas C, et al. An In Vitro alveolar macrophage assay for the assessment of inflammatory cytokine expression induced by atmospheric particulate matter. Environ Toxicol. 2015;30:836-51.

13. Nemmar A, Hoet PH, Vanquickenborne B, Dinsdale D, Thomeer $M$, Hoylaerts MF, et al. Passage of inhaled particles into the blood circulation in humans. Circulation. 2002;105:411-414.

14. Pant $P$ and Harrison RM. Estimation of the contribution of road traffic emissions to particulate matter concentrations from field measurements: A review. Atmospheric Environment. 2013;77:78-97.

15. Guarieiro LGA. Vehicle Emissions: What will change with use of biofuel? INTECH Open Acces Publisher. 2013.

16. Wheeler BW, Lovell R, Higgins SL, White MP, Alcock I, Osborne NJ, et al. Beyond greenspace: an ecological study of population general health and 
indicators of natural environment type and quality. Int 3 Health Geogr. 2015;14:17.

17. James P, Banay RF, Hart JE and Laden F. A Review of the Health Benefits of Greenness. Curr Epidemiol Rep. 2015;2:131-142.

18. Brunekreef $\mathrm{B}$ and Holgate ST. Air pollution and health. Lancet. 2002;360:1233-1242.

19. Nawrot TS, Perez L, Kunzli N, Munters E and Nemery B. Public health importance of triggers of myocardial infarction: a comparative risk assessment. Lancet. 2011;377:732-740.

20. Katsouyanni K, Touloumi G, Spix C, Schwartz J, Balducci F, Medina S, et al. Short-term effects of ambient sulphur dioxide and particulate matter on mortality in 12 European cities: results from time series data from the APHEA project. Air Pollution and Health: a European Approach. BMJ (Clinical research ed). 1997;314:1658-63.

21. WHO. Burden of disease from Ambient Air Pollution for 2012. 2014.

22. Guarnieri M and Balmes JR. Outdoor air pollution and asthma. Lancet. 2014;383:1581-92.

23. Ling $\mathrm{SH}$ and van Eeden SF. Particulate matter air pollution exposure: role in the development and exacerbation of chronic obstructive pulmonary disease. Int J Chron Obstruct Pulmon Dis. 2009;4:233-43.

24. Gauderman WJ, Avol E, Gilliland F, Vora H, Thomas D, Berhane K, et al. The effect of air pollution on lung development from 10 to 18 years of age. The New England journal of medicine. 2004;351:1057-67.

25. Anderson JO, Thundiyil JG and Stolbach A. Clearing the air: a review of the effects of particulate matter air pollution on human health. Journal of medical toxicology : official journal of the American College of Medical Toxicology. 2012;8:166-75.

26. Martinelli N, Olivieri $\mathrm{O}$ and Girelli D. Air particulate matter and cardiovascular disease: a narrative review. Eur $J$ Intern Med. 2013;24:295-302.

27. Brook RD, Rajagopalan S, Pope CA, III, Brook JR, Bhatnagar A, DiezRoux $A V$, et al. Particulate matter air pollution and cardiovascular disease: An update to the scientific statement from the American Heart Association. Circulation. 2010;121:2331-2378.

28. Behrman RE and Butler AS. Washington (DC): National Academies Press (US); 2007.

29. McIntire DD, Bloom SL, Casey BM and Leveno KJ. Birth weight in relation to morbidity and mortality among newborn infants. The New England journal of medicine. 1999;340:1234-8.

30. Pedersen M, Giorgis-Allemand L, Bernard C, Aguilera I, Andersen A-M, Ballester $F$, et al. Ambient air pollution and low birthweight: a European cohort study (ESCAPE). Lancet Respir Med. 2013;1:695-704.

31. Dadvand P, Parker J, Bell ML, Bonzini M, Brauer M, Darrow LA, et al. Maternal exposure to particulate air pollution and term birth weight: a multi-country evaluation of effect and heterogeneity. EnvironHealth Perspect. 2013;121:267-373.

32. Sapkota A, Chelikowsky AP, Nachman KE, Cohen AJ and Ritz B. Exposure to particulate matter and adverse birth outcomes: a comprehensive review and meta-analysis. Air Qual Atmos Hith. 2012;5:369-381. 
33. Stieb DM, Chen L, Eshoul M and Judek S. Ambient air pollution, birth weight and preterm birth: a systematic review and meta-analysis. Environmental research. 2012;117:100-11.

34. Vieira SE. The health burden of pollution: the impact of prenatal exposure to air pollutants. Int $J$ Chron Obstruct Pulmon Dis. 2015;10:1111-21.

35. Baiz N, Slama R, Bene MC, Charles MA, Kolopp-Sarda MN, Magnan A, et al. Maternal exposure to air pollution before and during pregnancy related to changes in newborn's cord blood lymphocyte subpopulations. The EDEN study cohort. BMC Pregnancy Childbirth. 2011;11:87.

36. Brauer $M$, Lencar $C$, Tamburic $L$, Koehoorn $M$, Demers $P$ and Karr $C$. A cohort study of traffic-related air pollution impacts on birth outcomes. EnvironHealth Perspect. 2008;116:680-686.

37. Wilhelm $M$ and Ritz $B$. Residential proximity to traffic and adverse birth outcomes in Los Angeles county, California, 1994-1996. EnvironHealth Perspect. 2003;111:207-216.

38. Laurent $\mathrm{O}, \mathrm{Wu} \mathrm{J}, \mathrm{Li} \mathrm{L}$, Chung $\mathrm{J}$ and Bartell $\mathrm{S}$. Investigating the association between birth weight and complementary air pollution metrics: a cohort study. Environmental health : a global access science source. 2013;12:18.

39. Rice $M B$, Rifas-Shiman SL, Oken E, Gillman MW, Ljungman PL, Litonjua AA, et al. Exposure to traffic and early life respiratory infection: A cohort study. Pediatr Pulmonol. 2014.

40. Volk HE, Hertz-Picciotto I, Delwiche L, Lurmann F and McConnell R. Residential Proximity to Freeways and Autism in the CHARGE Study. Environmental Health Perspectives. 2011;119:873-877.

41. Hystad P, Davies HW, Frank L, Van Loon J, Gehring U, Tamburic L, et al. Residential greenness and birth outcomes: evaluating the influence of spatially correlated built-environment factors. Environ Health Perspect. 2014;122:1095-102.

42. Dadvand $P$, Sunyer J, Basagana X, Ballester F, Lertxundi A, FernandezSomoano $A$, et al. Surrounding greenness and pregnancy outcomes in four Spanish birth cohorts. Environ Health Perspect. 2012;120:1481-7.

43. Kihal-Talantikite W, Padilla CM, Lalloue B, Gelormini M, Zmirou-Navier D and Deguen S. Green space, social inequalities and neonatal mortality in France. BMC Pregnancy Childbirth. 2013;13:191.

44. Cheng $Z$ and Ristow M. Mitochondria and metabolic homeostasis. Antioxid Redox Signal. 2013;19:240-2.

45. Malik AN and Czajka A. Is mitochondrial DNA content a potential biomarker of mitochondrial dysfunction? Mitochondrion. 2013;13:48192.

46. Hou L, Zhang X, Dioni L, Barretta F, Dou C, Zheng Y, et al. Inhalable particulate matter and mitochondrial DNA copy number in highly exposed individuals in Beijing, China: a repeated-measure study. Particle and fibre toxicology. 2013;10:17.

47. Hou L, Zhu ZZ, Zhang X, Nordio F, Bonzini M, Schwartz J, et al. Airborne particulate matter and mitochondrial damage: a cross-sectional study. Environmental health : a global access science source. 2010;9:48.

48. Clemente DB, Casas $M$, Vilahur N, Begiristain $H$, Bustamante $M$, Carsin $A E$, et al. Prenatal Ambient Air Pollution, Placental Mitochondrial DNA 
Content, and Birth Weight in the INMA (Spain) and ENVIRAGE (Belgium) Birth Cohorts. Environ Health Perspect. 2015.

49. Janssen BG, Munters E, Pieters N, Smeets K, Cox B, Cuypers A, et al. Placental mitochondrial DNA content and particulate air pollution during in utero life. Environ Health Perspect. 2012;120:1346-1352.

50. Liu $\mathrm{P}$ and Demple $\mathrm{B}$. DNA repair in mammalian mitochondria: Much more than we thought? Environmental and molecular mutagenesis. 2010;51:417-26.

51. Lee $\mathrm{HC}$ and Wei $\mathrm{YH}$. Mitochondrial biogenesis and mitochondrial DNA maintenance of mammalian cells under oxidative stress. The international journal of biochemistry \& cell biology. 2005;37:822-34.

52. Blackburn EH. Switching and signaling at the telomere. Cell. 2001;106:661-673.

53. Harley $C B$, Futcher $A B$ and Greider CW. Telomeres shorten during ageing of human fibroblasts. Nature. 1990;345:458-60.

54. Wright WE, Piatyszek MA, Rainey WE, Byrd W and Shay JW. Telomerase activity in human germline and embryonic tissues and cells. Dev Genet. 1996;18:173-9.

55. Sanders JL and Newman AB. Telomere length in epidemiology: $a$ biomarker of aging, age-related disease, both, or neither? Epidemiol Rev. 2013;35:112-31.

56. Wentzensen IM, Mirabello L, Pfeiffer RM and Savage SA. The association of telomere length and cancer: a meta-analysis. Cancer epidemiology, biomarkers \& prevention : a publication of the American Association for Cancer Research, cosponsored by the American Society of Preventive Oncology. 2011;20:1238-50.

57. Ma H, Zhou Z, Wei S, Liu Z, Pooley KA, Dunning AM, et al. Shortened telomere length is associated with increased risk of cancer: a metaanalysis. PLoS One. 2011;6:e20466.

58. Zhao J, Miao K, Wang $H$, Ding $H$ and Wang DW. Association between telomere length and type 2 diabetes mellitus: a meta-analysis. PLoS One. 2013;8:e79993.

59. Haycock PC, Heydon E, Kaptoge S, Butterworth AS, Thompson A and Willeit $P$. Leucocyte telomere length and risk of cardiovascular disease: systematic review and meta-analysis. BMJ (Clinical research ed). $2014 ; 349$.

60. Kimura M, Hjelmborg JV, Gardner JP, Bathum L, Brimacombe M, Lu X, et al. Telomere length and mortality: a study of leukocytes in elderly Danish twins. American journal of epidemiology. 2008;167:799-806.

61. Bakaysa SL, Mucci LA, Slagboom PE, Boomsma DI, McClearn GE, Johansson $B$, et al. Telomere length predicts survival independent of genetic influences. Aging Cell. 2007;6:769-774.

62. Okuda K, Bardeguez A, Gardner JP, Rodriguez P, Ganesh V, Kimura M, et al. Telomere length in the newborn. PediatrRes. 2002;52:377-381.

63. Broer L, Codd V, Nyholt DR, Deelen J, Mangino M, Willemsen G, et al. Meta-analysis of telomere length in 19713 subjects reveals high heritability, stronger maternal inheritance and a paternal age effect. EurJHumGenet. 2013:1163-1168.

64. Hoxha M, Dioni L, Bonzini M, Pesatori AC, Fustinoni S, Cavallo D, et al. Association between leukocyte telomere shortening and exposure to 
traffic pollution: a cross-sectional study on traffic officers and indoor office workers. EnvironHealth. 2009;8:41.

65. McCracken J, Baccarelli A, Hoxha M, Dioni L, Melly S, Coull B, et al. Annual ambient black carbon associated with shorter telomeres in elderly men: Veterans Affairs Normative Aging Study. EnvironHealth Perspect. 2010;118:1564-1570.

66. Grahame TJ and Schlesinger RB. Oxidative stress-induced telomeric erosion as a mechanism underlying airborne particulate matter-related cardiovascular disease. Part Fibre Toxicol. 2012;9:21.

67. von Zglinicki T. Role of oxidative stress in telomere length regulation and replicative senescence. AnnNYAcadSci. 2000;908:99-110.

68. Colin Mathers GS, Maya Mascarenhas. Global Health Risks: Mortality and burden of disease attributable to selected major risks. 2009:70.

69. WHO. Global atlas on cardiovascular disease prevention and control Policies, strategies and interventions. 2011:1+4.

70. Hansen TW, Jeppesen J, Rasmussen S, Ibsen $\mathrm{H}$ and Torp-Pedersen C. Ambulatory blood pressure and mortality: a population-based study. Hypertension. 2005;45:499-504.

71. Slama M, Susic D and Frohlich ED. Prevention of hypertension. Curr Opin Cardiol. 2002;17:531-6.

72. Fuks K, Moebus S, Hertel S, Viehmann A, Nonnemacher M, Dragano N, et al. Long-term urban particulate air pollution, traffic noise, and arterial blood pressure. Environ Health Perspect. 2011;119:1706-11.

73. Fuks KB, Weinmayr G, Foraster M, Dratva J, Hampel R, Houthuijs D, et al. Arterial blood pressure and long-term exposure to traffic-related air pollution: an analysis in the European Study of Cohorts for Air Pollution Effects (ESCAPE). Environ Health Perspect. 2014;122:896-905.

74. Hu Z, Liebens J and Rao KR. Linking stroke mortality with air pollution, income, and greenness in northwest Florida: an ecological geographical study. Int J Health Geogr. 2008; 7:20.

75. Richardson EA and Mitchell R. Gender differences in relationships between urban green space and health in the United Kingdom. Social science \& medicine (1982). 2010;71:568-75.

76. Tamosiunas A, Grazuleviciene R, Luksiene D, Dedele A, Reklaitiene R, Baceviciene $M$, et al. Accessibility and use of urban green spaces, and cardiovascular health: findings from a Kaunas cohort study. Environmental health : a global access science source. 2014;13:20.

77. Markevych I, Thiering E, Fuertes E, Sugiri D, Berdel D, Koletzko S, et al. A cross-sectional analysis of the effects of residential greenness on blood pressure in 10-year old children: results from the GINIplus and LISAplus studies. BMC Public Health. 2014;14:477.

78. Demerath EW, Cameron N, Gillman MW, Towne B and Siervogel RM. Telomeres and telomerase in the fetal origins of cardiovascular disease: a review. Hum Biol. 2004;76:127-46.

79. de Boo HA and Harding JE. The developmental origins of adult disease (Barker) hypothesis. Aust N Z J Obstet Gynaecol. 2006;46:4-14.

80. Osmond $C$ and Barker DJ. Fetal, infant, and childhood growth are predictors of coronary heart disease, diabetes, and hypertension in adult men and women. Environ Health Perspect. 2000;108 Suppl 3:545-53. 
81. Barker DJ, Bull AR, Osmond C and Simmonds SJ. Fetal and placental size and risk of hypertension in adult life. BMJ (Clinical research ed). 1990;301:259-62.

82. Barker DJ. The fetal and infant origins of adult disease. BMJ (Clinical research ed). 1990;301:1111.

83. Barker DJ. Fetal origins of coronary heart disease. BMJ (Clinical research ed). 1995;311:171-4.

84. Barker DJ and Osmond C. Infant mortality, childhood nutrition, and ischaemic heart disease in England and Wales. Lancet. 1986;1:1077-81.

85. Barker DJ. Intrauterine programming of coronary heart disease and stroke. Acta Paediatr Suppl. 1997;423:178-82; discussion 183.

86. Barker DJ, Winter PD, Osmond C, Margetts B and Simmonds SJ. Weight in infancy and death from ischaemic heart disease. Lancet. 1989;2:57780.

87. Barker DJ. The origins of the developmental origins theory. $J$ Intern Med. 2007;261:412-7.

88. Ravelli GP, Stein ZA and Susser MW. Obesity in young men after famine exposure in utero and early infancy. The New England journal of medicine. 1976;295:349-53.

89. van den Hooven EH, Pierik FH, de Kluizenaar $Y$, Hofman A, van Ratingen SW, Zandveld PY, et al. Air pollution exposure and markers of placental growth and function: the generation R study. Environ Health Perspect. 2012;120:1753-9. 


\section{CHAPTER 2}

\section{Small for gestational age and exposure to particulate air pollution in the early-life environment of twins}

Esmée M Bijnens ${ }^{1,2}$, Catherine Derom ${ }^{3}$, Marij Gielen ${ }^{2}$, Ellen Winckelmans ${ }^{1}$, Frans Fierens ${ }^{4}$, Robert Vlietinck $^{3}$, Maurice $P$ Zeegers $^{2}$, Tim S Nawrot ${ }^{1,5}$

1. Centre for Environmental Sciences, Hasselt University, Diepenbeek, Belgium

2. Department of Complex Genetics, NUTRIM School of Nutrition and Translational Research in Metabolism, Maastricht University Medical Centre, Maastricht, The Netherlands

3. Centre of Human Genetics, University Hospitals Leuven, Leuven, Belgium

4. Belgian Interregional Environment Agency, Brussel, Belgium

5. Department of Public Health, Leuven University (KU Leuven), Leuven, Belgium 


\section{ABSTRACT}

Several studies in singletons have shown that maternal exposure to ambient air pollutants is associated with restricted fetal growth. About half of twins have low birth weight compared with six percent in singletons. So far, no studies have investigated maternal air pollution exposure in association with birth weight and small for gestational age in twins.

We examined 4760 twins of the East Flanders Prospective Twin Survey (20022013), to study the association between in utero exposure to air pollution with birth weight and small for gestational age. Maternal particulate air pollution $\left(\mathrm{PM}_{10}\right)$ and nitric dioxide $\left(\mathrm{NO}_{2}\right)$ exposure was estimated using a spatial temporal interpolation method over various time windows during pregnancy.

In twins born between 32-36 weeks of gestation, birth weight decreased by 40.2 g (95\% CI: -69.0 to $-11.3 ; p=0.006)$ and by $27.3 \mathrm{~g}(95 \% \mathrm{CI}:-52.9$ to $-1.7 ; \mathrm{p}=$ $0.04)$ in association with a $10 \mathrm{\mu g} / \mathrm{m}^{3}$ increment in $\mathrm{PM}_{10}$ and $\mathrm{NO}_{2}$ concentration during the third trimester. The corresponding odds ratio for small for gestational age were 1.68 (95\% CI: 1.27 to $2.33 ; p=0.0003$ ) and 1.51 (95\% CI: 1.18 to $1.95 ; p=0.001)$ for $\mathrm{PM}_{10}$ or $\mathrm{NO}_{2}$, respectively. No associations between air pollution and birth weight or small for gestational age were observed among term born twins.

Assuming causality, an achievement of a $10 \mu \mathrm{g} / \mathrm{m}^{3}$ decrease of particulate air pollution may account for a reduction by $40 \%$ in small for gestational age, in twins born moderate to late preterm. 


\section{INTRODUCTION}

Low birth weight and small for gestational age are associated with increased neonatal morbidity and mortality.1,2 The consequences of low birth weight and being born small for gestational age occur not only in the neonatal period but also in adulthood. These newborns are possibly at increased risk for developing heart and metabolic disease later in life according to the 'Barker hypothesis'. ${ }^{3,4}$

Several studies have shown that maternal exposure to ambient air pollutants during pregnancy is associated with restricted fetal growth in singletons. ${ }^{5-8}$ Heterogeneity of study designs, exposure period and exposure assessment exits, but meta-analyses have shown that particulate matter with an aerodynamic diameter of less than $10 \mu \mathrm{m}\left(\mathrm{PM}_{10}\right)$ is negatively associated with term birth weight. ${ }^{6,8}$ In addition, a European multi cohort study found that $\mathrm{PM}_{10}$ and $\mathrm{NO}_{2}$ are associated with increased risk of low birth weight at term. ${ }^{5}$ Besides birth weight, small for gestational age (SGA) has been found to be associated with ambient air pollution. ${ }^{9-12}$ A population-based cohort study in the Netherlands demonstrated an association between small for gestational age and $\mathrm{PM}_{10}$ exposure. ${ }^{9}$ Based on ultra sound measurements they suggest that maternal $\mathrm{PM}_{10}$ exposure is inversely associated with fetal growth during the second and third trimester. ${ }^{9}$ Large studies in Detroit and Sydney show similar observations for $\mathrm{PM}_{10}{ }^{10,11}$ In addition, adverse effects of $\mathrm{NO}_{2}$ on fetal growth restriction among singleton births were noted in Canadian cities. ${ }^{12}$

However to the best of our knowledge, no studies have investigated the association of air pollution with birth weight and small for gestational age in twins. The growth of a twin fetus differs from a singleton after 32 weeks of gestation probably due to the restricted capability of the uterine environment to nurture more than one fetus at a time. ${ }^{13}$ This finally results in decreased birth weight and increased odds of perinatal mortality. ${ }^{14}$ Therefore, twins could have potentially increased vulnerability to in utero exposure to air pollution. 


\section{METHODS}

\section{Subjects}

The East Flanders Prospective Twin Survey (EFPTS) is a population based register of multiple births in the province of East-Flanders (Belgium). ${ }^{15}$ The twins are ascertained at birth. We geocoded the addresses of 5190 twin born between 2001 and 2013. We excluded still-born twins $(n=56)$ or twins suffering from major congenital malformation $(n=70)$. We excluded twins with missing data; birth weight $(n=20)$, gestational age $(n=20)$, zygosity $(n=240)$, maternal age $(n=6)$, parity $(n=18)$. This resulted in a final study population of 4760 persons.

\section{Tissue sampling and zygosity determination}

A trained midwife examined the placentas within 24 hours after delivery following a standardized protocol. ${ }^{16}$ Fetal membranes were dissected, and after removing the membranes and blood clots, the fresh unfixed placentas were weighed, and their length and thickness were measured. Zygosity was determined by sequential analysis based on sex, choriontype, blood group determined on umbilical cord blood, DNA fingerprints. ${ }^{17}$ After DNAfingerprinting, a zygosity probability of 0.999 was reached.

\section{Data collection}

Data recorded by the obstetrician at birth included gestational age, newborns birth weight, sex of the twins, birth date, maternal age, parity, mode of delivery and mode of conception, and live born versus stillborn. Gestational age was based on the last menstruation or on a first trimester ultrasound investigation and was calculated as the number of completed weeks of pregnancy. We classified births as small for gestational age when birth weight was below the $10^{\text {th }}$ percentile of the birth weight for a given gestational age and gender according to cut-off values based on data from twin births in Flanders from the Study Centre for Perinatal Epidemiology (SPE) in the period 2001-2010. ${ }^{18}$ We gathered information on neighbourhood socio economic status. All mothers were assigned to statistical sectors (average area $=1.55 \mathrm{~km}^{2}$ ), the smallest administrative entity for which statistical data are produced by the Belgian 22 
National Institute of Statistics (NIS), based on their home address. Belgian census data (FOD Economie/DG Statistiek) derived from the NIS were used to define neighbourhood socio economic status based on annual household income (2005).

\section{Exposure assessment}

Regional background levels of $\mathrm{PM}_{10}$ for each mother's residential address were estimated using a spatial temporal interpolation method (Kriging) that uses land cover data obtained from satellite images (Corine land cover data set) in combination with monitoring stations ( $\mathrm{n}=19,44$ for $\mathrm{PM}_{10}$ and $\mathrm{NO}_{2}$ in 2002). ${ }^{19}$ This model provides interpolated daily $\mathrm{PM}_{10}$ values in $4 \times 4 \mathrm{~km}$ grids from the Belgian telemetric air quality networks.

Individual mean $\mathrm{PM}_{10}$ concentrations (micrograms per cubic meter) were calculated for various periods: last month and week of pregnancy and each of the three trimesters of pregnancy, with trimesters being defined as: 1-13 weeks (trimester 1), 14-26 weeks (trimester 2) and 27 weeks to delivery (trimester 3). This provides the opportunity to explore potentially critical exposure periods during pregnancy. Additionally, $\mathrm{NO}_{2}$ exposure was interpolated using the same methods as $\mathrm{PM}_{10}$ exposure.

\section{Statistical analysis}

For data management and statistical analyses, we used SAS software, version 9.3 (SAS Institute, Cary, NC). All reported p-values are two-sided and were considered statistically significant when $p<0.05$. The normal distribution of all quantitative variables was visually inspected in QQ-plots.

Mixed modeling was performed to investigate the association between birth weight and air pollution exposure. The twins were analyzed as individuals in a multilevel regression analysis. To account for relatedness between twin members a random intercept was added to the model. The variance-covariance structure was allowed to differ between the three zygosity-chorionicity groups. Potential confounders and covariates were selected a priori including newborn's 
sex, birth order, parity, gestational age (linear and quadratic), season of birth, birth year, zygosity and chorionicity, maternal age and neighbourhood household income.

A generalized linear mixed model was used to investigate the association between the binary outcome small for gestational age and air pollution exposure. In this model similar covariates were used, with exception of newborn's sex and gestational age.

In addition, we formally tested the air pollution by zygosity interaction on birth weight.

Based on previous evidence between air pollution and birth weight in singleton births 20,21 and differences in growth patterns of twins over gestational age compared with singletons, ${ }^{22-24}$ we stratified the analysis a priori in term ( $>36$ weeks), moderate to late preterm (32-36 weeks) and very preterm $(<32$ weeks).

\section{RESULTS}

\section{Characteristics of the study population}

Characteristics of the study population are given in Table 1 . This study contains 4760 newborn twins of which 1242 (26.1\%) monozygotic and 3518 (73.9\%) dizygotic twins. Most (51.8\%) of the 2409 mothers were primiparous and had an average age of 30 years. The median annual income (2005) of the area of residence was 19,904 euro. The mean gestational age was 35.8 weeks. Only $43.9 \%$ were term births and most births (50.0\%) were born moderate to late preterm and $6.1 \%$ very preterm. Birth weight averaged (SD) 2431 (525) g and half of the newborns were boys. Nine percent of the twins were small for gestational age. Table 2 contains the distribution of the air pollution exposure during the trimesters and time periods. The mean residential $\mathrm{PM}_{10}$ and $\mathrm{NO}_{2}$ exposure during pregnancy were 30.7 (27.4-33.6) $\mu \mathrm{g} / \mathrm{m}^{3}$ and $24.4(20.0-28.3)$ $\mu \mathrm{g} / \mathrm{m}^{3}$, respectively. 
Table 1 Study population characteristics

\begin{tabular}{|c|c|c|c|c|}
\hline Characteristic & Total & Term & $\begin{array}{l}\text { Moderate to } \\
\text { late preterm }\end{array}$ & Very preterm \\
\hline Maternal & $(n=2409)$ & $(n=1054)$ & $(n=1204)$ & $(n=151)$ \\
\hline Maternal Age (years) & $30.3 \pm 4.6$ & $30.6 \pm 4.6$ & $30.2 \pm 4.6$ & $29.3 \pm 4.3$ \\
\hline$<20$ & $25(1.0)$ & $10(1.0)$ & $15(1.3)$ & $0(0)$ \\
\hline $20-29$ & $1016(42.2)$ & $401(38.0)$ & $534(44.3)$ & $81(53.7)$ \\
\hline $30-35$ & $1040(43.2)$ & $487(46.2)$ & $498(41.4)$ & $55(36.4)$ \\
\hline$>35$ & $328(13.6)$ & $156(14.8)$ & $157(13.0)$ & $15(9.9)$ \\
\hline \multicolumn{5}{|l|}{ Parity } \\
\hline 1 & $1247(51.8)$ & $482(45.7)$ & $661(54.9)$ & $104(68.9)$ \\
\hline$>1$ & $1162(48.2)$ & $572(54.3)$ & $543(45.1)$ & $47(31.1)$ \\
\hline $\begin{array}{l}\text { Neighbourhood income } \\
\text { (euro) }\end{array}$ & $19904 \pm 3125$ & $19911 \pm 3172$ & $19908 \pm 3102$ & $19831 \pm 2987$ \\
\hline Newborn & $(n=4760)$ & $(n=2088)$ & $(n=2380)$ & $(n=292)$ \\
\hline Gestational age (weeks) & $35.8 \pm 2.4$ & $37.7 \pm 0.8$ & $34.9 \pm 1.3$ & $29.7 \pm 1.6$ \\
\hline \multicolumn{5}{|l|}{ Zygosity-Chorionicity } \\
\hline Dizygotic-Dichorial & 3518 (73.9) & $1598(76.5)$ & $1715(72.1)$ & $205(70.2)$ \\
\hline Monozygotic-Dichorial & $393(8.3)$ & $172(8.3)$ & $196(8.2)$ & $25(8.6)$ \\
\hline Monozygotic-Monochorial & $849(17.8)$ & $318(15.2)$ & $469(19.7)$ & $62(21.2)$ \\
\hline \multicolumn{5}{|l|}{ Sex } \\
\hline Male & $2357(49.5)$ & $1006(48.2)$ & 1187 (49.9) & $164(56.2)$ \\
\hline Female & $2403(50.5)$ & $1082(51.8)$ & $1193(50.1)$ & $128(43.8)$ \\
\hline Newborns birth weight $(\mathrm{g})$ & $2431 \pm 525$ & $2733 \pm 399$ & $2294 \pm 406$ & $1388 \pm 338$ \\
\hline Twin birth year & $2007 \pm 3.2$ & $2007 \pm 3.1$ & $2007 \pm 3.2$ & $2008 \pm 3.0$ \\
\hline Small for gestational age & $428(9.0)$ & $216(10.3)$ & $193(8.1)$ & $19(6.5)$ \\
\hline
\end{tabular}

Data presented are means \pm standard deviation or number

\section{Birth weight in association with air pollution exposure}

Both before and after adjustment for previously mentioned covariates, birth weight was inversely associated with $\mathrm{PM}_{10}$ and $\mathrm{NO}_{2}$. The trimester specific exposure windows show that the association between air pollution and birth weight was mainly driven by exposure during the third trimester (Table3). For each $10 \mu \mathrm{g} / \mathrm{m}^{3}$ increase in maternal $\mathrm{PM}_{10}$ exposure during the third trimester, birth weight decreased by $40.2 \mathrm{~g}$ ( $95 \% \mathrm{CI}:-69.0$ to $-11.3 ; p=0.006$ ) among moderate to late preterm twins. The corresponding estimate for a $10 \mu \mathrm{g} / \mathrm{m}^{3}$ increase in $\mathrm{NO}_{2}$ was $-27.3 \mathrm{~g}(95 \% \mathrm{CI}$ : -52.9 to $-1.7 ; p=0.04)$. Stratified 
analysis revealed no significant associations between air pollution exposure and birth weight among term and very preterm twins. No significant interaction by zygosity in the model of air pollution and birth weight was observed $(p \geq 0.47)$.

Table 2 Exposure characteristics

\begin{tabular}{|c|c|c|c|c|c|c|c|c|c|}
\hline \multicolumn{10}{|c|}{ Percentile } \\
\hline Pollution indicator & Mean & SD & Min & 5 th & 25th & 50th & 75th & 95th & Max \\
\hline \multicolumn{10}{|l|}{$\mathrm{PM}_{10}, \boldsymbol{\mu g} / \mathrm{m}^{3}$} \\
\hline Trimester 1 & 30.8 & 6.0 & 16.5 & 20.8 & 26.6 & 31.0 & 34.8 & 40.7 & 57.1 \\
\hline Trimester 2 & 30.7 & 6.3 & 13.8 & 20.5 & 26.6 & 30.8 & 34.8 & 40.9 & 54.4 \\
\hline Trimester 3 & 30.3 & 7.1 & 13.2 & 19.5 & 25.2 & 30.2 & 34.7 & 42.4 & 64.4 \\
\hline Last month & 30.2 & 8.1 & 12.3 & 18.4 & 24.1 & 29.6 & 35.3 & 44.8 & 66.4 \\
\hline Last week & 30.1 & 11.3 & 9.8 & 16.8 & 21.9 & 27.5 & 36.2 & 53.2 & 82.7 \\
\hline Whole pregnancy & 30.7 & 4.7 & 18.4 & 22.9 & 27.4 & 30.7 & 33.6 & 38.5 & 49.3 \\
\hline \multicolumn{10}{|l|}{$\mathrm{NO}_{2}, \mu \mathrm{g} / \mathrm{m}^{3}$} \\
\hline Trimester 1 & 24.4 & 7.1 & 6.4 & 13.6 & 19.1 & 23.9 & 28.7 & 37.5 & 46.4 \\
\hline Trimester 2 & 24.4 & 7.2 & 6.6 & 13.3 & 19.3 & 24.0 & 29.0 & 37.6 & 51.9 \\
\hline Trimester 3 & 24.2 & 7.7 & 5.0 & 12.7 & 18.8 & 23.7 & 29.0 & 38.8 & 48.9 \\
\hline Last month & 24.1 & 8.0 & 4.2 & 12.2 & 18.2 & 23.5 & 29.1 & 38.9 & 54.9 \\
\hline Last week & 24.0 & 9.4 & 2.0 & 10.8 & 17.2 & 22.8 & 29.5 & 41.4 & 72.5 \\
\hline Whole pregnancy & 24.4 & 5.9 & 8.6 & 16.2 & 20.0 & 23.6 & 28.3 & 35.2 & 46.5 \\
\hline
\end{tabular}

\section{Small for gestational age in association with air pollution exposure}

The analysis of trimester specific exposure windows shows that the effect on small for gestational age was also mainly driven via exposure during the third trimester (Table 4). The odds ratio for small for gestational age was 1.68 (95\% CI: 1.27 to $2.23 ; p=0.0003$ ) and 1.51 odds ratio (95\% CI: 1.18 to 1.95 ; $p=0.001$ ) for each $10 \mu \mathrm{g} / \mathrm{m}^{3}$ increase in $\mathrm{PM}_{10}$ or $\mathrm{NO}_{2}$, respectively, during the third trimester in twins born moderate to late preterm. The aforementioned odds ratio's were adjusted for previously mentioned covariates. Stratified analysis revealed no significant associations between air pollution exposure and small for gestational age among term twins as well as in the group of very preterm. 


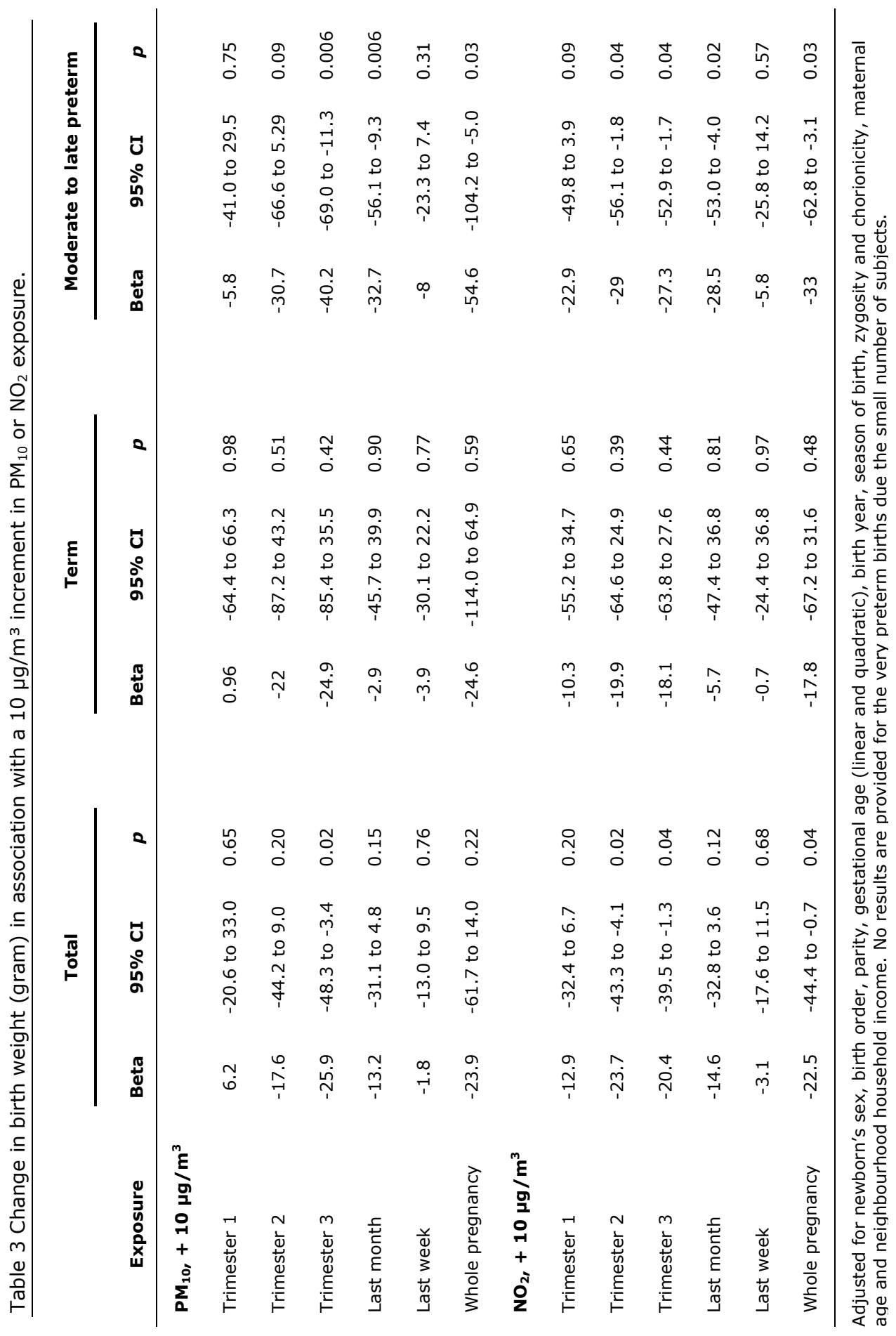




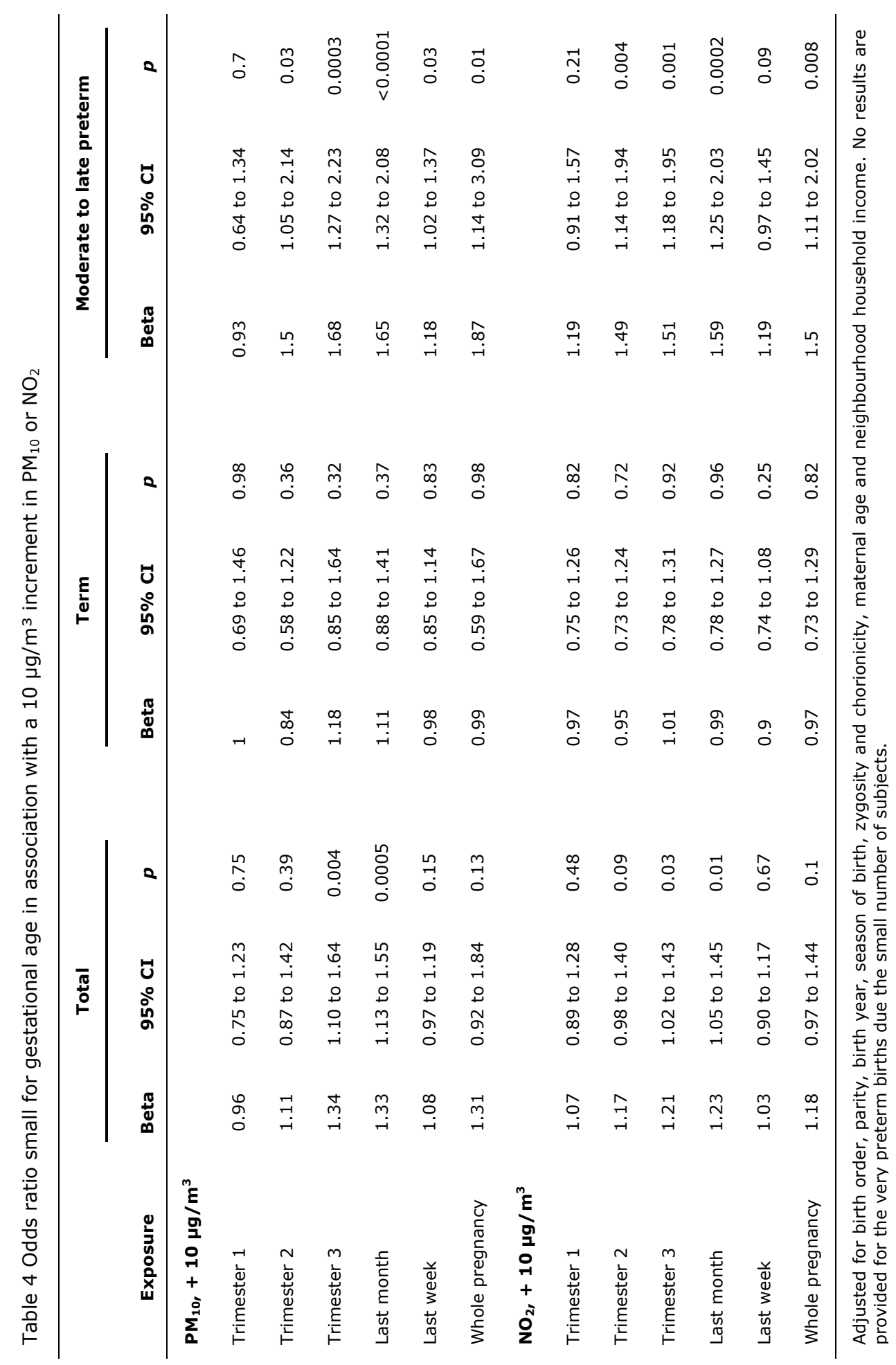




\section{DISCUSSION}

We investigated for the first time the association between small for gestational age and in utero exposure to air pollution in twins. In twins born between 32-36 weeks, the odds of small for gestational age increased by $68 \%$ (95\% CI: 27 to 123) and 51\% (95\% CI: 18 to 95) for each $10 \mu \mathrm{g} / \mathrm{m}^{3}$ increment in $\mathrm{PM}_{10}$ or $\mathrm{NO}_{2}$ during the third trimester. The corresponding estimates for $\mathrm{PM}_{10}$ and $\mathrm{NO}_{2}$ on birth weight showed a reduction of $40.2 \mathrm{~g}$ (95\% CI: -69.0 to -11.3 ) and $27.3 \mathrm{~g}$ (95\% CI: -52.9 to -1.7 ), respectively. These estimates are considerable higher than previously reported estimates in term born singletons. An European multi cohort study in singletons observed that a $10 \mu \mathrm{g} / \mathrm{m}^{3}$ increased $\mathrm{PM}_{10}$ and $\mathrm{NO}_{2}(10$ $\mu \mathrm{g} / \mathrm{m}^{3}$ ) concentration during third trimester correspond to a decrease of $6 \mathrm{~g}$ (95\% CI: -15 to 2 ) and $3 \mathrm{~g}$ (95\% CI: -7 to 2 ) in birth weight. ${ }^{25}$ A meta-analysis noted a decrease of $2 \mathrm{~g}(95 \% \mathrm{CI}:-7$ to 3$)$ and $2 \mathrm{~g}$ (95\% CI: -8 to 4$)$ and in birth weight for a $10 \mu \mathrm{g} / \mathrm{m}^{3}$ increase in $\mathrm{PM}_{10}$ and $\mathrm{NO}_{2}$ concentration. In contrast to these studies in term born singletons, in our study air pollution was not associated with birth weight nor with small for gestational age, in term born twins.

Twin pregnancies account for a disproportionate degree of maternal and fetal workload, in which perinatal complications have been attributed to growth aberrations in one or both twins. Twin specific growth charts show a deviation of twin birth weights after 33 weeks of gestation compared with singletons. ${ }^{22-24}$. Twins are already at elevated risk for low birth weight since about half of twins have low birth weight compared with $6 \%$ in singletons. ${ }^{26}$ Data from a US birth register. ${ }^{27}$ shows that twins account for $23 \%$ of all low birth weights.

Three studies observed that fetal growth reduction ${ }^{20,21}$ or very low birth weight 28 (below the 10th percentile for birth weight, given their gestational age, race, and gender) in singletons born before 37 weeks, showed stronger effects of air pollution compared with their term born counterparts. They suggest that air pollution promotes growth restriction among fetuses already at risk. ${ }^{20}$ In addition possible explanation may be the difference in intrauterine growth between singletons and twins. Twins achieve optimal intrauterine growth and 
development earlier in gestation. ${ }^{29}$ In addition, the weight of singletons increases up to 42 weeks, whereas the curve of twins shows dip after 40 weeks of gestation, which is mainly due to the contribution of monochorionic twins. ${ }^{24}$ This suggests that fetal weight is most affected by air pollution exposure before 37 weeks since twins gain most of their weight before 37 weeks. In addition, a study in 4232 twins observed that the effect of genetics and common environmental factors on birth weight decreases from 25 weeks to the end of gestation, ${ }^{30}$ possibly due to restricted capability of the uterine environment in twin gestation. ${ }^{13,30}$

Strengths of this study included information on chorionicity and the availability of geocoding of individual residences. However, exposure estimates were based on the residential address of the mother at time of birth of the twin and no information was available on time spend in traffic, occupational activities, moving during pregnancy. Although we controlled for a number of potential confounders, maternal smoking, a known risk factor for poor birth outcomes, is not included in this analysis. Insertion of the umbilical cord is also associated with birth weight, ${ }^{31}$ however, we did not adjust for this in our models since information on umbilical cord insertion was missing for a large number of twins, especially for twins with opposite sex. No information on diet, drinking and smoking habits during pregnancy were available. On the other hand a large number of important covariates was taken into account: newborn's sex, birth order, parity, gestational age, season of birth, birth year, maternal age and neighbourhood household income. In addition, information on zygosity and chorionicity, important tools in twin research, were available for all twins in this study. It is reasonable to assume that social economic indicators such as neighbourhood household income partly account for nutrition and lifestyle. ${ }^{32}$

Our findings have public health relevance. Although intrauterine growth in twins may be different from that in singletons, the associations between birth weight and cardiovascular risk in twins suggest that birth weight in twins is relevant to the development of cardiovascular disease ${ }^{33}$ and related to adult blood pressure. ${ }^{34,35}$ The $\mathrm{PM}_{10}$ exposure during the third trimester $\left(30.3 \mu \mathrm{g} / \mathrm{m}^{3}\right)$ in our population was 1.5 times higher than the annual limit value of WHO $\left(20 \mu \mathrm{g} / \mathrm{m}^{3}\right)$. If a reduction of $10 \mu \mathrm{g} / \mathrm{m}^{3}$ would be achieved this is likely to prevent $40 \%$ of the 30 
twins who were small for gestational age in moderate to late preterm births. Our data shows that the WHO limit value is highly relevant for the protection of vulnerable population groups such as twins in their early-life development.

\section{FUNDING}

This work was supported by the EU research council "project ENVIRONAGE" [ERC-2012-StG 310890], Flemish Scientific fund [G087311N10, GOA7814N, $1516112 \mathrm{~N}$ ] and Bijzonder Onderzoeksfonds (tUL-funding). Since its origin the East Flanders Prospective Twin Survey has been partly supported by grants from the Fund of Scientific Research, Flanders and Twins, a non-profit Association for Scientific Research in Multiple Births (Belgium). The medical ethics committee of the Hasselt University approved the research protocol. 


\section{REFERENCES}

1. Behrman RE and Butler AS. Washington (DC): National Academies Press (US); 2007.

2. McIntire DD, Bloom SL, Casey BM and Leveno KJ. Birth weight in relation to morbidity and mortality among newborn infants. The New England journal of medicine. 1999;340:1234-8.

3. Osmond C and Barker DJ. Fetal, infant, and childhood growth are predictors of coronary heart disease, diabetes, and hypertension in adult men and women. Environ Health Perspect. 2000;108 Suppl 3:545-53.

4. Levy-Marchal $C$ and Jaquet D. Long-term metabolic consequences of being born small for gestational age. Pediatric diabetes. 2004;5:147-53.

5. Pedersen M, Giorgis-Allemand L, Bernard C, Aguilera I, Andersen A-M, Ballester $F$, et al. Ambient air pollution and low birthweight: a European cohort study (ESCAPE). Lancet Respir Med. 2013;1:695-704.

6. Dadvand $P$, Parker J, Bell ML, Bonzini M, Brauer M, Darrow LA, et al. Maternal exposure to particulate air pollution and term birth weight: a multi-country evaluation of effect and heterogeneity. EnvironHealth Perspect. 2013;121:267-373.

7. Sapkota A, Chelikowsky AP, Nachman KE, Cohen AJ and Ritz B. Exposure to particulate matter and adverse birth outcomes: a comprehensive review and meta-analysis. Air Qual Atmos Hith. 2012;5:369-381.

8. Stieb DM, Chen L, Eshoul M and Judek S. Ambient air pollution, birth weight and preterm birth: a systematic review and meta-analysis. Environmental research. 2012;117:100-11.

9. van den Hooven $\mathrm{EH}$, Pierik FH, de Kluizenaar $\mathrm{Y}$, Willemsen SP, Hofman A, van Ratingen SW, et al. Air pollution exposure during pregnancy, ultrasound measures of fetal growth, and adverse birth outcomes: a prospective cohort study. Environ Health Perspect. 2012;120:150-6.

10. Le HQ, Batterman SA, Wirth JJ, Wahl RL, Hoggatt KJ, Sadeghnejad A, et al. Air pollutant exposure and preterm and term small-for-gestationalage births in Detroit, Michigan: long-term trends and associations. Environment international. 2012;44:7-17.

11. Mannes T, Jalaludin B, Morgan G, Lincoln D, Sheppeard V and Corbett S. Impact of ambient air pollution on birth weight in Sydney, Australia. Occupational and environmental medicine. 2005;62:524-30.

12. Liu S, Krewski D, Shi Y, Chen $Y$ and Burnett RT. Association between maternal exposure to ambient air pollutants during pregnancy and fetal growth restriction. Journal of exposure science \& environmental epidemiology. 2007; 17:426-32.

13. Blickstein I. Intrauterine Growth. In: L. Keith, ed. Multiple pregnanciy: epidemiology, gestation \& perinatal outcome New York: The Parthenon Publishing Group; 1995: 503-513.

14. Hack KE, Derks JB, Elias SG, Franx A, Roos EJ, Voerman SK, et al. Increased perinatal mortality and morbidity in monochorionic versus dichorionic twin pregnancies: clinical implications of a large Dutch cohort study. BJOG : an international journal of obstetrics and gynaecology. 2008;115:58-67. 
15. Derom C, Thiery E, Peeters $H$, Vlietinck R, Defoort $P$ and Frijns JP. The East Flanders Prospective Twin Survey (EFPTS): an actual perception. Twin research and human genetics: the official journal of the International Society for Twin Studies. 2013;16:58-63.

16. Derom R, Derom C and Vlietinck R. Placentation. In: K. LG, ed. Multiple pregnancy: Epidemiology, Gestation \& Perinatal outcome New York: The Parthenon Publishing Group; 1995: 113-128.

17. Vlietinck R. Determination of the zygosity of twins Leuven: Katholieke Universiteit Leuven; 1986: 1-123.

18. Cox B, Martens E, Nemery B, Vangronsveld J and Nawrot TS. Impact of a stepwise introduction of smoke-free legislation on the rate of preterm births: analysis of routinely collected birth data. BMJ (Clinical research ed). 2013;346:f441.

19. Janssen S, Dumont G, Fierens F and Mensink C. Spatial interpolation of air pollution measurements using CORINE land cover data. Atmospheric Environment. 2008;42:4884-4903.

20. Pereira G, Cook AG, Haggar F, Bower C and Nassar N. Locally derived traffic-related air pollution and fetal growth restriction: a retrospective cohort study. Occupational and environmental medicine. 2012;69:81522.

21. Winckelmans E, Cox B, Martens E, Nemery B and Nawrot TS. Fetal growth and maternal exposure to particulate air pollution; More marked effects at lower exposure and modification by gestational duration. Submitted.

22. Loos RJ, Derom C, Derom R and Vlietinck R. Determinants of birthweight and intrauterine growth in liveborn twins. Paediatric and perinatal epidemiology. 2005;19 Suppl 1:15-22.

23. Odibo AO, Cahill AG, Goetzinger KR, Harper LM, Tuuli MG and Macones GA. Customized growth charts for twin gestations to optimize identification of small-for-gestational age fetuses at risk of intrauterine fetal death. Ultrasound in obstetrics \& gynecology : the official journal of the International Society of Ultrasound in Obstetrics and Gynecology. 2013;41:637-42.

24. Gielen M, Lindsey PJ, Derom C, Loos RJ, Souren NY, Paulussen AD, et al. Twin-specific intrauterine 'growth' charts based on cross-sectional birthweight data. Twin research and human genetics : the official journal of the International Society for Twin Studies. 2008;11:224-35.

25. Pedersen M, Giorgis-Allemand L, Bernard C, Aguilera I, Andersen AM, Ballester $F$, et al. Ambient air pollution and low birthweight: a European cohort study (ESCAPE). Lancet Respir Med. 2013;1:695-704.

26. Martin JA, Hamilton BE, Osterman MJ, Curtin SC, Mathews MA and Mathews TJ. Births: final data for 2012. National vital statistics reports : from the Centers for Disease Control and Prevention, National Center for Health Statistics, National Vital Statistics System. 2013;62:1-27.

27. Martin JA, Hamilton BE, Ventura SJ, Osterman MJ, Kirmeyer S, Mathews TJ, et al. Births: final data for 2009. National vital statistics reports : from the Centers for Disease Control and Prevention, National Center for Health Statistics, National Vital Statistics System. 2011;60:1-70.

28. Rogers JF and Dunlop AL. Air pollution and very low birth weight infants: a target population? Pediatrics. 2006;118:156-64. 
29. Minakami $\mathrm{H}$ and Sato I. Reestimating date of delivery in multifetal pregnancies. JAMA : the journal of the American Medical Association. 1996;275:1432-4.

30. Gielen M, Lindsey PJ, Derom C, Smeets HJ, Souren NY, Paulussen AD, et al. Modeling genetic and environmental factors to increase heritability and ease the identification of candidate genes for birth weight: a twin study. BehavGenet. 2008;38:44-54.

31. Loos RJ, Derom C, Derom R and Vlietinck R. Birthweight in liveborn twins: the influence of the umbilical cord insertion and fusion of placentas. BJOG : an international journal of obstetrics and gynaecology. 2001;108:943-8.

32. Ritz B and Wilhelm M. Ambient air pollution and adverse birth outcomes: methodologic issues in an emerging field. Basic \& clinical pharmacology \& toxicology. 2008;102:182-90.

33. Ijzerman RG, Boomsma DI and Stehouwer CD. Intrauterine environmental and genetic influences on the association between birthweight and cardiovascular risk factors: studies in twins as a means of testing the fetal origins hypothesis. Paediatric and perinatal epidemiology. 2005;19 Suppl 1:10-4.

34. Loos RJ, Fagard R, Beunen G, Derom C and Vlietinck R. Birth weight and blood pressure in young adults: a prospective twin study. Circulation. 2001;104:1633-8.

35. Poulter NR, Chang CL, MacGregor AJ, Snieder $\mathrm{H}$ and Spector TD. Association between birth weight and adult blood pressure in twins: historical cohort study. BMJ (Clinical research ed). 1999;319:1330-3. 


\section{CHAPTER 3}

\section{Placental mitochondrial DNA content is associated with maternal residential traffic and greenness: a twin study}

Esmée M Bijnens ${ }^{1,2}$, Tim S Nawrot ${ }^{1,3}$, Catherine Derom ${ }^{4,5}$, Bram G Janssen ${ }^{1}$, Karen Vrijens ${ }^{1}$, Harry A Roels ${ }^{1,6}$, Robert Vlietinck ${ }^{4}$, Marij Gielen ${ }^{2}$, Maurice P Zeegers ${ }^{2}$

1. Centre for Environmental Sciences, Hasselt University, Diepenbeek, Belgium

2. Department of Complex Genetics, NUTRIM School of Nutrition and Translational Research in Metabolism, Maastricht University Medical Centre, Maastricht, The Netherlands

3. Department of Public Health, Leuven University (KU Leuven), Leuven, Belgium

4. Centre of Human Genetics, University Hospitals Leuven, Leuven, Belgium

5. Department of Obstetrics and Gynaecology, Ghent University Hospital, Ghent, Belgium

6. Louvain Centre for Toxicology and Applied Pharmacology, Université catholique de Louvain, Brussels, Belgium 


\section{ABSTRACT}

Residential traffic exposure is an important environmental source of free radical production. Oxidative stress may stimulate mitochondrial proliferation to supply energy, however the increasing abundance of dysfunctional mitochondria causes further oxidative damage. We investigated maternal residential traffic and greenness exposure in association with mitochondrial DNA content in placental tissue of twins.

Among 175 twins of the East Flanders Prospective Twin Survey, maternal traffic exposure was determined using Geographic Information Systems and we measured mitochondrial DNA content in placental tissue.

Large effects of the environment on mitochondrial DNA content were observed, while genetic factors appeared to play a minor role. In addition, maternal residential proximity to traffic and land use indicators were significantly associated with placental mitochondrial DNA content. A doubling in distance to the nearest major road resulted in a decrease in mitochondrial DNA content of $8.32 \%$ (95 CI: -13.8 to $-2.5 \% ; p=0.008$ ). An interquartile range increase in residential surrounding greenness in a $100 \mathrm{~m}$ to $5 \mathrm{~km}$ residential radius was associated with a decrease of 5.61 to $10.04 \%$ in mitochondrial DNA content.

We showed that placental mitochondrial DNA content is more influenced by environmental factors than genetic factors and is associated with maternal residential greenness and traffic indicators. Higher mitochondrial DNA content might both intensify and/or be a reflection of oxidative stress. Our molecular epidemiological findings may lend support to urban planners to promote local greenness for healthy living from early-life onwards. 


\section{INTRODUCTION}

Human ageing entails increased oxidative damage and mutations in mitochondrial DNA while the cellular respiration and ATP generation of mitochondria decline. ${ }^{1,2}$ Changes in mitochondrial DNA content have been reported in a several human diseases such as human immunodeficiency virus (HIV), metabolic disorders and a wide variety of cancers. ${ }^{3}$ Mild oxidative stress may stimulate mitochondrial biogenesis as an adaptive response to supply energy needed for cell survival, this is accompanied by an increased mitochondrial DNA content. However, long-term exposure to oxidative stress leads to oxidative damage to mitochondria and other intracellular constituents including DNA, RNA, proteins, and lipids. This could result in mitochondrial dysfunction causing excess generation of reactive oxygen species and further oxidative damage which ultimately may lead to cell apoptosis. ${ }^{4}$ Mitochondrial DNA is more vulnerable for oxidative damage than nuclear DNA due the lack of protective histones and a less efficient DNA repair system.

Twin studies can provide an estimation of the genetic heritability of mitochondrial DNA content. Besides genetic factors, environmental exposures can affect mitochondrial DNA content. Associations were observed between mitochondrial DNA content and traffic exposure, ${ }^{5,6}$ an important environmental source of reactive oxygen generating species. ${ }^{7}$ However until now only one study investigated the association between traffic exposure and mitochondrial DNA content in placental tissue ${ }^{8}$ and no studies are available on greenness in association with mitochondrial DNA content. We hypothesize that greenness could influence mitochondrial DNA content not only via oxidative stress reduction but also via psychological stress perception. In the current study, we examined maternal residential greenness and traffic exposure during pregnancy in association with placental mitochondrial DNA content in twins. 


\section{METHODS}

\section{Subjects}

The East Flanders Prospective Twin Survey (EFPTS), a population-based register of multiple births in the province of East-Flanders (Belgium), started in 1964 to enrol twins at birth. ${ }^{9}$ The twin-population of our investigation was based on a previous twin study by Loos et al. (2001). ${ }^{10}$ From this population we could obtain 231 twins of Caucasian Belgian origin born between 1975 and 1982 . Important for the selection was also the fact that major changes in the road network no longer occurred in East-Flanders since 1974. As we used for the study the placenta of the selected twins, we had to exclude twins with bad or doubtful total DNA quality $(n=33)$, irreproducible triplicate values of mitochondrial DNA content $(n=16)$, no information on residential address of the mother $(n=7)$, resulting in a final study population of 175 twins.

\section{Data collection}

Data recorded by the obstetrician at birth included gestational age, birth weight, sex of the twins and parental ages. Gestational age was based on the last menstruation and was calculated as the number of completed weeks of pregnancy.

At a later stage, the parents of the twins filled out questionnaires. In this way, information on maternal smoking during pregnancy and parental education were collected retrospectively. Educational level as a proxy of socio economic status (SES) was categorized into three groups according to the Belgian education system; no education or primary school, lower secondary education, and higher secondary education and tertiary education. In addition to individual SES data, we gathered information on neighborhood SES. Based on their home address, all mothers were assigned to statistical sectors (average area $=1.55 \mathrm{~km}^{2}$ ), the smallest administrative entity for which statistical data are produced by the Belgian National Institute of Statistics (NIS). Belgian census data (FOD Economie/DG Statistiek) derived from the NIS were used to define neighborhood SES based on annual household income in the year 1994. 


\section{Tissue sampling and zygosity determination}

At time of birth, placentas were examined within 24 hours after delivery by a trained midwife following a standardized protocol. ${ }^{11}$ Fetal membranes were dissected, and after removing the membranes and blood clots, the fresh unfixed placentas were weighed, and their length and thickness were measured. For each twin, placental biopsies were taken close to the surface near the insertion of the umbilical cord and stored at $-20^{\circ} \mathrm{C}$ in a biobank.

Zygosity was determined by sequential analysis based on sex, choriontype, blood group determined on umbilical cord blood, placental alkaline phosphatase, and, since 1982, DNA fingerprints. ${ }^{12}$ After DNA-fingerprinting, a zygosity probability of $0.999 \%$ was reached.

\section{Measurement of mitochondrial DNA content}

DNA was isolated from placental tissue using the QIAamp DNeasy blood and tissue kit (Qiagen, Venlo, The Netherlands), following the instructions of the manufacturer for animal tissues. Quality and concentration of the isolated placental DNA was assessed using the Nanodrop 1000 spectrophotometer (Isogen Life Science, Belgium). Placental samples with a low DNA yield or absorption ratios for $A 260 / A 280$ that were outside the range of 1.8-2.0 were excluded $(n=33)$.

The method for measuring mitochondrial DNA content was described previously. ${ }^{8,13}$ Relative mitochondrial DNA content was measured in placental tissue using a quantitative real-time polymerase chain reaction ( $q P C R$ ) assay by determining the ratio of two mitochondrial gene copy numbers [MTF3212/R3319 (mitochondrial forward primer from nucleotide 3212 and reverse primer from nucleotide 3319) and MT-ND1 (mitochondrial encoded NADH dehydrogenase 1)] to two single-copy nuclear control genes [RPLPO (acidic ribosomal phosphoprotein P0) and ACTB (beta actin)]. Extracted genomic DNA was diluted to a final concentration of $5 \mathrm{ng} / \mu \mathrm{L}$ in RNase free water prior to the qPCR runs. $A$ $10 \mu \mathrm{L}$ PCR reaction mixture contained Fast SYBR® Green I dye $2 \times$ mastermix (Life Technologies, Foster City, CA, USA), forward $(10 \mu \mathrm{M})$ and reverse $(10 \mu \mathrm{M})$ 
primer, and $2.5 \mu \mathrm{L}$ of DNA sample. Primer sequences were described previously. ${ }^{8}$ Each PCR reaction was carried out in triplicate and three nontemplate controls as well as five inter-run calibrators were included on each 384-well plate. All samples were analyzed with the 7900HT Fast Real-Time PCR system (Life Technologies). The thermal cycling profile was the same for all

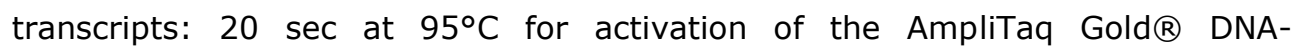
polymerase, followed by 40 cycles of $1 \mathrm{sec}$ at $95^{\circ} \mathrm{C}$ for denaturation and $20 \mathrm{sec}$ at $60^{\circ} \mathrm{C}$ for annealing/extension. Amplification specificity and absence of primer dimers was confirmed by melting curve analysis at the end of each run (15 sec at $95^{\circ} \mathrm{C}, 15 \mathrm{sec}$ at $60^{\circ} \mathrm{C}, 15 \mathrm{sec}$ at $95^{\circ} \mathrm{C}$ ).

After thermal cycling, raw data were collected and processed. $\mathrm{C}_{\mathrm{T}}$ (cycle threshold)-values of the two mitochondrial genes were normalized relative to the two nuclear reference genes according to the qBase software (Biogazelle, Zwijnaarde, Belgium). The program uses modified software from the classic comparative $\mathrm{C}_{\mathrm{T}}$ method that takes multiple reference genes into account and uses inter-run calibration algorithms to correct for run-to-run differences. ${ }^{14}$ The coefficient of variation for the mitochondrial DNA content in inter-run samples was $5.0 \%$. All samples were analyzed in triplicate and included in the study when the difference in quantification cycle $(\mathrm{Cq})$ value was $<0.50$.

\section{Traffic exposure and land use data}

Residential addresses of the mothers at birth were geocoded. Distances to the nearest major road with traffic counts available and traffic density were determined using Geographic Information System (GIS) functions. All GIS analyses were carried out using ArcGIS 10 software. We collected information on two traffic indicators at the mother's residence, i.e., distance to major road and traffic density. Traffic density within a $200 \mathrm{~m}$ radius (buffer) from the residence was equal to the length of each road in this buffer multiplied with the traffic count on each specific road. This was calculated for a $200 \mathrm{~m}$ buffer in steps of $10 \mathrm{~m}$. Traffic counts of 2010 were obtained from the Traffic Centre Flanders, Department of Mobility and Public Works. Streets with low traffic-carrying capacity codes without traffic measurements were assigned a default traffic count of 543 vehicles per 24 hours. Traffic densities within a buffer were 40 
multiplied by a weight decreasing with distance, following a Gaussian curve. ${ }^{15}$ Finally the sum was made for the distance-weighted traffic densities (DWTD) in all buffers within $200 \mathrm{~m}$. This was also repeated for 50, 100 and $150 \mathrm{~m}$ buffers.

Semi-natural -, forested -, and agricultural areas (greenness), residential and industrial areas in a $5000 \mathrm{~m}$ radius from the residential address were estimated based on Corine land cover 2000 (European Environment Agency). This was repeated for 4000, 3000, 2000, 1000, 500, 300 and 100 m buffers. In addition, residential surrounding greenness was also assessed using the Normalized Difference Vegetation Index (NDVI) based on Moderate Resolution Imaging Spectroradiometer (MODIS) images processed by the Flemish Institute for Technological Research (VITO) with a $250 \mathrm{~m}$ resolution. NDVI is an indicator of greenness based on land surface reflectance of visible (red) and near-infrared parts of spectrum. Annual NDVI values were calculated for the year 2000 based on 10-day average measurements.

\section{Statistical analysis}

For data management and statistical analyses, we used SAS software, version 9.3 (SAS Institute, Cary, NC). All reported $p$ values are two-sided and were considered statistically significant when $p<0.05$. The distribution of all quantitative variables was visually inspected in QQ-plots. Traffic indicators were log-transformed to assure normality. Mixed modeling was performed to investigate mitochondrial DNA content in association with traffic exposure and land-use indicators. The twins were analyzed as individuals in a multilevel regression analysis to account for relatedness between twin members by adding a random intercept to the model. The variance-covariance structure was allowed to differ between the three zygosity-chorionicity groups including dizygotic dichorionic, monozygotic dichorionic, and monozygotic monochorionic. Covariates were selected a priori including newborn's sex, gestational age (linear and quadratic), birth weight, birth year (linear and quadratic), season of birth, zygosity-chorionicity group, maternal age, indicators of socioeconomic status (maternal education and neighborhood household income), and smoking during pregnancy. 


\section{Estimation of mitochondrial DNA content by genetic versus environmental factors}

Structural equation modelling was performed with Open Mx software ${ }^{16}$ in complete pairs (110 twins) with the significant traffic exposure indicators from the mixed models to estimate the genetic and environmental components of variance of placental mitochondrial DNA content. The variance was decomposed in additive genetic (A), common environmental (C), and unique environmental (E) effects. Common environmental effects are similar between twins such as maternal exposure whereas unique environmental effect are different for both twins such as insertion of the umbilical cord and unequal blood supply. This is the classic ACE model. ${ }^{17}$ The model makes use of the fact that monozygotic (MZ) twins are genetically identical, whereas dizygotic (DZ) twins share half of their genes.

With regard to structural equation modelling the appropriate assumptions were checked first and shown to be satisfactory; there were no significant differences in means or variances of mitochondrial DNA content between twin 1 and twin 2 in $M Z$ and $D Z$ twins. The significance of the components in the model was tested by dropping these parameters and comparing the fit of the models by use of a maximum-likelihood. The model with the lowest Akaike's information criterion (AIC) was preferred. In addition, the difference in fit between the models was evaluated with the likelihood ratio chi-square test, which uses the difference between the -2 log likelihood ( $\triangle-2 L L$ ) of the full (ACE) and the restricted model ( $C E$ and $A E$ ).

The analyses were performed four times: first (1) the unadjusted placental mitochondrial DNA content and then (2) placental mitochondrial DNA content adjusted for previously mentioned covariates in the means model. Next (3), we adjusted for traffic variable distance to major road and covariates. Additionally (4), the analyses were also performed adjusted for greenness in a buffer of $5000 \mathrm{~m}$ and covariates. 


\section{RESULTS}

\section{Characteristics of the study population}

Table 1 summarizes the characteristics of the study population including 118 mothers and the 175 twins: $65.1 \%(n=114)$ of the participants included both twins from each twin pair, whereas the remaining $34.9 \%(n=61)$ only had one participating twin from each twin pair. Overall maternal age averaged about 28 years and ranged from 19 to 40 years. Among the mothers, $36.4 \% \quad(n=43)$ smoked before pregnancy and $11.0 \%(n=13)$ of the mothers continued smoking during pregnancy.

Table 1 Study population characteristics

\begin{tabular}{|c|c|c|}
\hline Characteristic & Monozygotic twins & Dizygotic twins \\
\hline Mother & $(n=76)$ & $(n=42)$ \\
\hline Maternal Age (years) & $27.2 \pm 4.2$ & $28.1 \pm 4.1$ \\
\hline$<20$ & $2(2.6)$ & $0(0)$ \\
\hline $20-29$ & $56(73.7)$ & $27(64.3)$ \\
\hline $30-35$ & $16(21.1)$ & $13(30.9)$ \\
\hline$>35$ & $2(2.6)$ & $2(4.8)$ \\
\hline \multicolumn{3}{|l|}{ Maternal education } \\
\hline Low & $29(38.2)$ & $16(38.1)$ \\
\hline Middle & $13(17.1)$ & $10(23.8)$ \\
\hline High & $34(44.7)$ & $16(38.1)$ \\
\hline Neighborhood income (euro/year) & $19,651 \pm 4,533$ & $18,681 \pm 4,035$ \\
\hline \multicolumn{3}{|l|}{ Smoking } \\
\hline Never & $43(56.6)$ & $19(45.2)$ \\
\hline Before pregnancy & $23(30.3)$ & $20(47.6)$ \\
\hline Before and during pregnancy & $10(13.1)$ & $3(7.2)$ \\
\hline Newborn & $(n=108)$ & $(n=67)$ \\
\hline Gestational age (weeks) & $37.3 \pm 2.5$ & $37.5 \pm 2.1$ \\
\hline \multicolumn{3}{|l|}{ Sex } \\
\hline Male-Male & $52(48.1)$ & $27(40.3)$ \\
\hline Female-Female & $56(51.9)$ & $27(40.3)$ \\
\hline Male-Female & $0(0.0)$ & $13(19.4)$ \\
\hline \multicolumn{3}{|l|}{ Choriontype } \\
\hline Monochorial & $50(46.3)$ & $0(0.0)$ \\
\hline Dichorial & $58(53.7)$ & $67(100)$ \\
\hline \multicolumn{3}{|l|}{ Complete-pair in final study } \\
\hline Twin with 1 individual in study & $44(40.7)$ & $17(25.4)$ \\
\hline Twin with 2 individuals in study & $64(59.3)$ & $50(74.6)$ \\
\hline Neonate birth weight $(\mathrm{g})$ & $2552 \pm 522$ & $2622 \pm 439$ \\
\hline Twin birth year & $1978 \pm 1.8$ & $1978 \pm 1.9$ \\
\hline
\end{tabular}


The twin population comprises 86 (48.1\%) males and 89 (50.9\%) females. The twins had an overall mean gestational age of 37.4 weeks (range 28-42) and a mean ( $(\mathrm{SD})$ birth weight of 2,579 $\pm 492 \mathrm{~g}$. Our analysis included $108(61.7 \%)$ monozygotic twins and 67 (38.3\%) dizygotic twins. We observed no significant differences between monozygotic and dizygotic twins for gestational age, birth weight, birth year and all the maternal characteristics. The mean relative placental mitochondrial DNA content was $1.29 \pm 0.95$. Table 2 shows the distribution of the traffic indicators and Table 3 the distribution of the land use indicators. The average distance from the participant's home address to the nearest major road was $417 \mathrm{~m}$ (interquartile range $(\mathrm{IQR})=204-1202 \mathrm{~m}$ ). The mean land use in percentiles in a $5000 \mathrm{~m}$ buffer was $3.1 \%$ of industrial area $(\mathrm{IQR}=1.2-6.5 \%), 28 \%$ of residential area $(\mathrm{IQR}=23-39 \%)$ and $68 \%$ of greenness $(\mathrm{IQR}=48-74 \%)$.

Table 2 Distribution of traffic indicators

\begin{tabular}{|c|c|c|c|c|c|c|}
\hline & \multicolumn{6}{|c|}{ Percentile } \\
\hline Traffic indicator & $\begin{array}{l}\text { Geometric } \\
\text { mean }\end{array}$ & $5^{\text {th }}$ & $25^{\text {th }}$ & $50^{\text {th }}$ & $75^{\text {th }}$ & $95^{\text {th }}$ \\
\hline Distance to major road, $\mathrm{m}$ & 417 & 27 & 204 & 433 & 1202 & 3123 \\
\hline \multicolumn{7}{|c|}{$\begin{array}{l}\text { Distance-weighted traffic density, } \\
\text { vehicles } \times \mathrm{km} / \text { day: }\end{array}$} \\
\hline $50 \mathrm{~m}$ buffer & 65 & 0 & 32 & 43 & 71 & 716 \\
\hline $100 \mathrm{~m}$ buffer & 137 & 32 & 69 & 99 & 158 & 1508 \\
\hline $150 \mathrm{~m}$ buffer & 189 & 46 & 99 & 139 & 298 & 1953 \\
\hline $200 \mathrm{~m}$ buffer & 199 & 48 & 103 & 153 & 331 & 1975 \\
\hline
\end{tabular}


Table 3 Distribution of land use indicators

\begin{tabular}{|c|c|c|c|c|c|c|}
\hline \multicolumn{7}{|c|}{ Percentile } \\
\hline Traffic indicator & Mean & $5^{\text {th }}$ & $25^{\text {th }}$ & $50^{\text {th }}$ & $75^{\text {th }}$ & $95^{\text {th }}$ \\
\hline \multicolumn{7}{|l|}{ Greenness, \%: } \\
\hline $5000 \mathrm{~m}$ buffer & 61 & 23 & 48 & 68 & 74 & 82 \\
\hline $1000 \mathrm{~m}$ buffer & 42 & 0 & 18 & 44 & 65 & 84 \\
\hline $100 \mathrm{~m}$ buffer & 17 & 0 & 0 & 0 & 25 & 100 \\
\hline \multicolumn{7}{|c|}{ Residential area, \%: } \\
\hline 5000 m buffer & 32 & 14 & 23 & 28 & 39 & 59 \\
\hline $1000 \mathrm{~m}$ buffer & 53 & 15 & 33 & 54 & 72 & 89 \\
\hline $100 \mathrm{~m}$ buffer & 81 & 0 & 71 & 100 & 100 & 100 \\
\hline \multicolumn{7}{|c|}{ Industrial area, \%: } \\
\hline $5000 \mathrm{~m}$ buffer & 3.92 & 0.00 & 1.16 & 3.06 & 6.50 & 9.01 \\
\hline $1000 \mathrm{~m}$ buffer & 3.53 & 0.00 & 0.00 & 0.00 & 5.13 & 18.86 \\
\hline $100 \mathrm{~m}$ buffer & 0.72 & 0.00 & 0.00 & 0.00 & 0.00 & 0.00 \\
\hline
\end{tabular}

\section{Placental mitochondrial DNA content in association with traffic exposure}

Placental mitochondrial DNA content is associated with residential proximity to the nearest major road after adjusting for the previously mentioned covariates. A doubling in the residential distance to the nearest major road was associated with a relative decrease of placental mitochondrial DNA content of $8.32 \%$ ( $95 \%$ $\mathrm{CI}$ : -13.8 to $-2.5 \% ; p=0.008$ ) (figure 1 ). Traffic density in multiple buffers (50 $\mathrm{m} ; 100 \mathrm{~m} ; 150 \mathrm{~m}$ and $200 \mathrm{~m}$ ) around the maternal residential address was significantly associated with mitochondrial DNA content in placental tissue. A doubling in distance-weighted traffic density within a $200 \mathrm{~m}$ maternal residential radius was associated with an increase in placental mitochondrial DNA content of $10.04 \%$ (95\% CI: 1.8 to $19.0 \%, p=0.02$ ). 


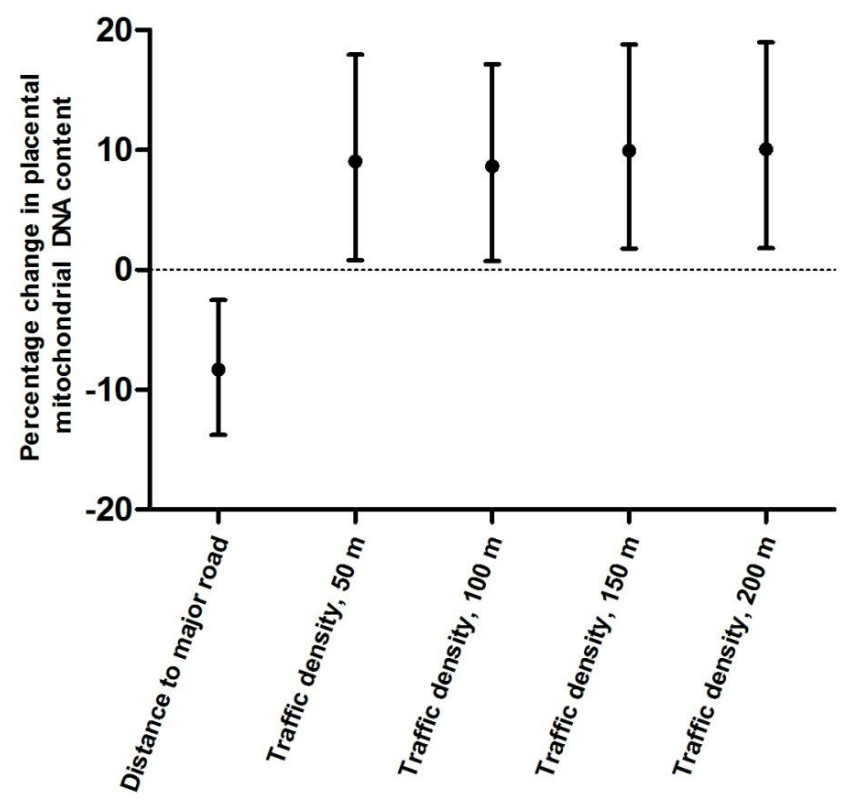

Figure 1 Percentage change in placental mitochondrial DNA content for a doubling in traffic indicators during pregnancy. Adjusted for newborn's sex, gestational age (linear and quadratic), birth weight, birth year (linear and quadratic), season of birth, zygosity-chorionicity group, maternal age, indicators of socioeconomic status (maternal education and neighborhood household income) and smoking during pregnancy. Vertical lines denote $95 \%$ confidence intervals. Traffic density equals distanceweighted traffic density.

\section{Placental mitochondrial DNA content in association with land use indicators}

For a $22 \%$ (IQR) increment of residential surrounding greenness in a $5000 \mathrm{~m}$ buffer, mitochondrial DNA content was $10.04 \%$ lower (95\% CI: -15.2 to $-4.5 \%$; $p=0.001$ ). The association between residential greenness and mitochondrial DNA content remained significant in smaller buffer sizes. Even the smallest buffer size $(100 \mathrm{~m})$ was significant. Similar results were obtained with the NDVI data (Supplement Table). In contrast to greenness, urbanisation indicators such as residential area and industry were associated with higher placental mitochondrial DNA content (figure 2). This was only significant for larger buffer sizes $(\geq 1000$ $\mathrm{m}$ for residential area and $\geq 3000 \mathrm{~m}$ for industrial area). 


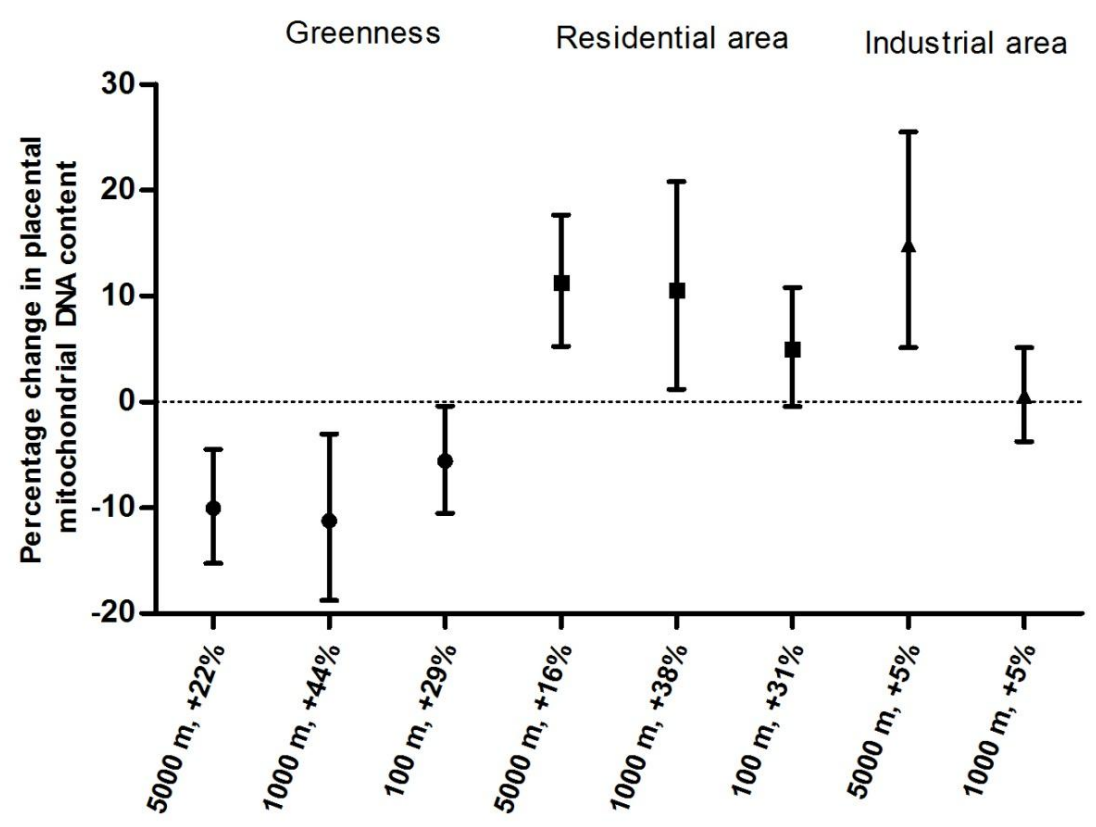

Figure 2 Percentage change in placental mitochondrial DNA content for an interquartile range increase in land use indicators during pregnancy. Adjusted for newborn's sex, gestational age (linear and quadratic), birth weight, birth year (linear and quadratic), season of birth, zygosity-chorionicity group, maternal age, indicators of socioeconomic status (maternal education and neighborhood household income) and smoking during pregnancy. Vertical lines denote $95 \%$ confidence intervals.

\section{Mitochondrial DNA content and its variation by genetic versus environmental factors}

For the variation in placental mitochondrial DNA content, we did not find evidence for a genetic component $(A)$, whereas common environmental sources (C) accounted for 49\% (95\% CI: 26 to $66 \%$ ) of the variance in the best-fitting (CE) model (Table 4). The fit of the ACE model in which the variance is decomposed into a genetic, common environment and unique environment was similar to the CE model (common environment and unique environment) and significantly better than the $\mathrm{AE}$ model (genetic and unique environment variance). 
The common environmental source still explained 36\% (95\% CI: 10 to 57\%) after adjusting for the covariables; newborn's sex, gestational age (linear and quadratic), birth weight, birth year (linear and quadratic), season of birth, zygosity-chorionicity group, maternal age, indicators of socioeconomic status (maternal education and neighborhood household income) and smoking during pregnancy. This indicates that other environmental factors must play an additional role. After adjusting for distance to major road and the previously mentioned covariates, the CE model remained the best-fitting model with common environmental sources explaining 34\% (95\% CI: 8 to 56\%).

Adjusting for greenness in a $5000 \mathrm{~m}$ buffer and other covariates gave similar results for the $\mathrm{CE}$ model as best-fitting model. The common environment accounted for $34 \%$ ( $95 \% \mathrm{CI}: 8$ to $55 \%$ ) of the total variance of mitochondrial DNA content.

Table 4 Mitochondrial DNA content and its variation by genetic and environmental factors

\begin{tabular}{|c|c|c|c|c|c|}
\hline \multicolumn{4}{|c|}{ Variance components } & \multicolumn{2}{|c|}{ Model fit } \\
\hline & $a^{2}$ & $c^{2}$ & $\mathrm{e}^{2}$ & AIC & $p(\Delta-2 \mathrm{LL})$ \\
\hline \multicolumn{6}{|c|}{ a) unadjusted } \\
\hline ACE & $0.00(0.00,0.40)$ & $0.49(0.09,0.66)$ & $0.51(0.34,0.74)$ & -156 & - \\
\hline CE & - & $0.49(0.26,0.66)$ & $0.51(0.34,0.74)$ & -158 & 1.00 \\
\hline $\mathrm{AE}$ & $0.46(0.20,0.65)$ & - & $0.54(0.35,0.80)$ & -154 & 0.03 \\
\hline \multicolumn{6}{|c|}{ b) adjusted for distance to major road + covariates } \\
\hline ACE & $0.00(0.00,0.47)$ & $0.34(0.00,0.56)$ & $0.66(0.44,0.92)$ & -132 & - \\
\hline $\mathrm{CE}$ & - & $0.34(0.08,0.56)$ & $0.66(0.44,0.92)$ & -134 & 1.00 \\
\hline $\mathrm{AE}$ & $0.31(0.02,0.54)$ & - & $0.69(0.46,0.98)$ & -132 & 0.13 \\
\hline
\end{tabular}

The table shows the proportion of unexplained variance for additive genetic $\left(a^{2}\right)$, common environmental $\left(c^{2}\right)$, and unique environmental factors $\left(e^{2}\right)$. ACE is a model that contained additive genetic, common environmental, and unique environmental factors; $A E$ is a model that contained additive genetic and unique environmental factors; $C E$ is a model that contained common environmental and unique environmental factors. Structural equation modelling was a) unadjusted, b) adjusted for distance to major road + covariates in the means model [ sex of newborn, gestational age (linear and quadratic), birth weight, birth year (linear and quadratic), season of birth, zygosity-chorionicity group, maternal age, socioeconomic status (maternal education and neighborhood household income), and smoking during pregnancy]; AIC, Akaike's information criterion; $-2 \mathrm{LL},-2$ log likelihood. 


\section{DISCUSSION}

Among 175 twins from the East Flanders Prospective Twin Study, we observed that placental mitochondrial DNA content was significantly associated with maternal residential traffic exposure and residential landscape: the more traffic exposure the more placental mitochondrial DNA content and the more greenness the less placental mitochondrial DNA content. It is know that mitochondrial DNA is highly susceptible to oxidative stress. Accumulation of mitochondrial DNA mutations lead to changes in mitochondrial biogenesis and function that might result in alterations of mitochondrial DNA content within cells. ${ }^{4}$ Traffic exposure results in oxidative stress formation, ${ }^{18}$ whereas exposure to green space serves as a buffer to decrease stress. ${ }^{19}$

This is the first study investigating the effect of greenness on mitochondrial DNA content in placental tissue. We observed lower placental mitochondrial DNA content in mothers with more greenness in the residential environment. In addition, a higher placental mitochondrial DNA content was noted in mothers exposed to more urbanisation indicators such as residential area and industry. We postulate that an underlying link between placental mitochondrial DNA content and residential greenness includes both psychological and biological (oxidative) stress. A Dutch study in 4,529 people showed that the effects of stressful life events were significantly moderated in those living in residential areas with high amounts of green space. ${ }^{19}$ Higher psychological stress is not only associated with shorter telomere length but also with oxidative stress ${ }^{20}$ as demonstrated at the cellular level by the relationship between stress hormones and oxidative stress. ${ }^{21,22}$ In addition, self-reported distress has also been related to greater oxidative DNA damage $(8-\mathrm{OH}-\mathrm{dG})$ in women. ${ }^{23}$ Oxidative stress stimulates mitochondrial proliferation resulting in excess reactive oxygen species (ROS) production. However, when the antioxidant capacity is compromised, the exposure to high levels of oxidative stress will result in defective mitochondria and mutated mitochondrial DNA, eventually resulting in a cyclic increase in ROS production and oxidative damage. ${ }^{4}$ 
Our findings of a higher mitochondrial DNA content in association with higher traffic density are consistent with studies reporting a positive association between smoking and mitochondrial DNA content in buccal cells and saliva. ${ }^{24,25}$ However, a decreased mitochondrial DNA content was noted in placental tissue of smoking women. ${ }^{26,27}$ Although our study contained only 13 women (11\%) who smoked during pregnancy, a trend towards a higher mitochondrial DNA content was observed (smokers vs non-smokers, 1.48 vs $1.30 ; p=0.15$ ).

Studies investigating the effect of particulate matter on mitochondrial DNA content showed opposite directions of the response to the exposure. Indeed, Hou et al. (2010) observed a positive association between PM exposure and mitochondrial DNA in blood of healthy steel workers as a result of long-term exposure, whereas mitochondrial DNA content was inversely associated with 8day average ambient $\mathrm{PM}_{10}$ concentrations in office workers. ${ }^{6}$ An inverse association between air pollution exposure and placental mitochondrial DNA content of singletons was noted by Janssen et al. (2012). This discrepancy can possibly be explained by sampling location on the placenta resulting in a different cell composition. ${ }^{8}$ Placental tissue biopsies in the study of Janssen et al. (2012) were taken at standardized locations across the middle region of the fetal side of the placenta, approximately $4 \mathrm{~cm}$ away from the umbilical cord. ${ }^{8}$ We took placental biopsies at the maternal side near the insertions of the umbilical cord. Differential mitochondrial features have been observed in placental intrauterine growth restriction which depends on the cell lineage. ${ }^{28}$

Changes in mitochondrial DNA content have been reported in a variety of human diseases including cancer, human immunodeficiency virus (HIV) and metabolic disorders such as diabetes and obesity. ${ }^{3}$ The potential health consequences of changes in mitochondrial DNA content in early-life are currently unknown. Our findings may be particularly relevant for policy makers and urban planners designing urban environments, since we observe that not only residential greenness in large buffer sizes $(5000 \mathrm{~m}$ ) but also greenness in a small radius $(100 \mathrm{~m})$ from the residential address is associated with a decrease in mitochondrial DNA content. 
We found low heritability and strong effects of the shared environment on mitochondrial DNA content in placental tissue. This is in contrast to other studies in adults were mitochondrial DNA content appears to have high heritability. Twin studies observed a heritability of mitochondrial DNA content $65 \%$ in peripheral blood lymphocytes ${ }^{29}$ and $35 \%$ in buccal cells. ${ }^{30}$ The estimated heritability of placental mitochondrial DNA content is similar to the heritability of telomere length in placental tissue. ${ }^{31}$ These data suggest that biomolecular markers of ageing, including mitochondrial DNA content and telomere length, ${ }^{32}$ depend in the placenta on environmental factors rather than genetic variation.

This is the first study to investigate mitochondrial DNA content in placental tissue in twins. The advantage of a twin study is that it can provide information on genetics versus environmental contributions in mitochondrial DNA content. Additional strengths of this study included information on chorionicity and the availability of geocoding of individual residences. The present study has also some limitations. The twins were born from 1975 till 1982 and the traffic counts dated from 2010. However, Pearson et al. (2000) compared traffic densities with an 11-year difference and observed an increase in traffic over time but the densities remained highly correlated. ${ }^{15}$ The land-use data dated from 2000 . No earlier satellite data on land-use were available. Therefore, it is unlikely that our results are influenced by potential time-dependent exposure misclassification.

\section{CONCLUSIONS}

In conclusion, mitochondrial DNA content in placental tissue, a molecular marker of mitochondrial damage, is associated with maternal traffic exposure and residential greenness. The consequences of an altered placental mitochondrial DNA content on health later in life are currently unknown and should be further elucidated in a prospective study. 


\section{FUNDING}

This investigation is supported by the EU research council "project ENVIRONAGE" (ERC-2012-StG 310890) and Flemish Scientific Fund (G073315N). Since its start, the East Flanders Prospective Twin Survey has been partly supported by grants from the Fund of Scientific Research Flanders and Twins, a non-profit Association for Scientific Research in Multiple Births (Belgium). 


\section{REFERENCES}

1. Krishnan KJ, Greaves LC, Reeve AK and Turnbull DM. Mitochondrial DNA mutations and aging. Annals of the New York Academy of Sciences. 2007; 1100:227-40.

2. Sastre J, Pallardo FV and Vina J. The role of mitochondrial oxidative stress in aging. Free radical biology \& medicine. 2003;35:1-8.

3. Malik AN and Czajka A. Is mitochondrial DNA content a potential biomarker of mitochondrial dysfunction? Mitochondrion. 2013;13:48192.

4. Lee $\mathrm{HC}$ and Wei $\mathrm{YH}$. Mitochondrial biogenesis and mitochondrial DNA maintenance of mammalian cells under oxidative stress. The international journal of biochemistry \& cell biology. 2005;37:822-34.

5. Hou L, Zhu ZZ, Zhang X, Nordio F, Bonzini M, Schwartz J, et al. Airborne particulate matter and mitochondrial damage: a cross-sectional study. Environmental health : a global access science source. 2010;9:48.

6. Hou L, Zhang X, Dioni L, Barretta F, Dou C, Zheng Y, et al. Inhalable particulate matter and mitochondrial DNA copy number in highly exposed individuals in Beijing, China: a repeated-measure study. Particle and fibre toxicology. 2013;10:17.

7. Lai CH, Liou SH, Lin HC, Shih TS, Tsai PJ, Chen JS, et al. Exposure to traffic exhausts and oxidative DNA damage. Occupational and environmental medicine. 2005;62:216-22.

8. Janssen BG, Munters E, Pieters N, Smeets K, Cox B, Cuypers A, et al. Placental mitochondrial DNA content and particulate air pollution during in utero life. Environ Health Perspect. 2012;120:1346-1352.

9. Derom C, Thiery E, Peeters $H$, Vlietinck R, Defoort P and Frijns JP. The East Flanders Prospective Twin Survey (EFPTS): an actual perception. Twin research and human genetics: the official journal of the International Society for Twin Studies. 2013;16:58-63.

10. Loos RJ, Beunen G, Fagard R, Derom C and Vlietinck R. The influence of zygosity and chorion type on fat distribution in young adult twins consequences for twin studies. Twin Res. 2001;4:356-364.

11. Derom R, Derom C and Vlietinck R. Placentation. In: K. LG, ed. Multiple pregnancy: Epidemiology, Gestation \& Perinatal outcome New York: The Parthenon Publishing Group; 1995: 113-128.

12. Vlietinck R. Determination of the zygosity of twins Leuven: Katholieke Universiteit Leuven; 1986: 1-123.

13. Pieters N, Koppen G, Smeets K, Napierska D, Plusquin M, De Prins S, et al. Decreased mitochondrial DNA content in association with exposure to polycyclic aromatic hydrocarbons in house dust during wintertime: from a population enquiry to cell culture. PLoS One. 2013;8:e63208.

14. Hellemans J, Mortier G, De Paepe A, Speleman F and Vandesompele J. qBase relative quantification framework and software for management and automated analysis of real-time quantitative PCR data. Genome biology. 2007;8:R19.

15. Pearson $\mathrm{RL}$, Wachtel $\mathrm{H}$ and Ebi $\mathrm{KL}$. Distance-weighted traffic density in proximity to a home is a risk factor for leukemia and other childhood cancers. J Air Waste Manag Assoc. 2000;50:175-180. 
16. Neale MC, Boker SM, Xie G and Maes HH. Mx: statistical modeling. 6th ed. Richmond, VA: Department of Psychiatry, Virginia Commonwealth University; 2003.

17. Neale MC and Maes HM. Methodology for Genetic Studies of Twins and Families. Dordrecht, The Netherlands: Academic Publishers B.V.; 2002.

18. Iwai K, Adachi S, Takahashi M, Moller L, Udagawa T, Mizuno S, et al. Early oxidative DNA damages and late development of lung cancer in diesel exhaust-exposed rats. Environ Res. 2000;84:255-264.

19. van den Berg AE, Maas J, Verheij RA and Groenewegen PP. Green space as a buffer between stressful life events and health. Social science \& medicine (1982). 2010;70:1203-10.

20. Epel ES, Blackburn EH, Lin J, Dhabhar FS, Adler NE, Morrow JD, et al. Accelerated telomere shortening in response to life stress. Proc Natl Acad Sci USA. 2004;101:17312-17315.

21. McIntosh LJ and Sapolsky RM. Glucocorticoids may enhance oxygen radical-mediated neurotoxicity. Neurotoxicology. 1996;17:873-82.

22. Patel R, McIntosh L, McLaughlin J, Brooke S, Nimon V and Sapolsky R. Disruptive effects of glucocorticoids on glutathione peroxidase biochemistry in hippocampal cultures. Journal of neurochemistry. 2002;82:118-25.

23. Irie $M$, Asami S, Ikeda M and Kasai $H$. Depressive state relates to female oxidative DNA damage via neutrophil activation. Biochem Biophys Res Commun. 2003;311:1014-8.

24. Tan D, Goerlitz DS, Dumitrescu RG, Han D, Seillier-Moiseiwitsch F, Spernak SM, et al. Associations between cigarette smoking and mitochondrial DNA abnormalities in buccal cells. Carcinogenesis. 2008;29:1170-7.

25. Masayesva BG, Mambo E, Taylor RJ, Goloubeva OG, Zhou S, Cohen Y, et al. Mitochondrial DNA content increase in response to cigarette smoking. Cancer epidemiology, biomarkers \& prevention : a publication of the American Association for Cancer Research, cosponsored by the American Society of Preventive Oncology. 2006;15:19-24.

26. Garrabou G, Hernandez AS, Catalan Garcia M, Moren C, Tobias E, Cordoba $S$, et al. Molecular basis of reduced birth weight in smoking pregnant women: mitochondrial dysfunction and apoptosis. Addiction biology. 2014:e12183.

27. Bouhours-Nouet N, May-Panloup P, Coutant R, de Casson FB, Descamps $P$, Douay $O$, et al. Maternal smoking is associated with mitochondrial DNA depletion and respiratory chain complex III deficiency in placenta. American journal of physiology Endocrinology and metabolism. 2005;288:E171-E177.

28. Mando C, De Palma C, Stampalija T, Anelli GM, Figus M, Novielli C, et al. Placental mitochondrial content and function in intrauterine growth restriction and preeclampsia. American journal of physiology Endocrinology and metabolism. 2014;306:E404-13.

29. Xing J, Chen M, Wood CG, Lin J, Spitz MR, Ma J, et al. Mitochondrial DNA content: its genetic heritability and association with renal cell carcinoma. J Natl Cancer Inst. 2008;100:1104-12. 
30. Reiling E, Ling C, Uitterlinden AG, Van't Riet E, Welschen LM, Ladenvall $C$, et al. The association of mitochondrial content with prevalent and incident type 2 diabetes. J Clin Endocrinol Metab. 2010;95:1909-15.

31. Bijnens E, Zeegers MP, Gielen M, Kicinski M, Hageman GJ, Pachen D, et al. Lower placental telomere length may be attributed to maternal residential traffic exposure; a twin study. Environment international. 2015;79:1-7.

32. Pieters N, Janssen BG, Valeri L, Cox B, Cuypers A, Dewitte $H$, et al. Molecular responses in the telomere-mitochondrial axis of ageing in the elderly: a candidate gene approach. Mech Ageing Dev. 2015;145:51-7. 
Supplement table 1 Land use indicators in association with placental mitochondrial DNA content

\begin{tabular}{|c|c|c|c|}
\hline $\begin{array}{l}\text { Land use indicators } \\
\text { (increase in IQR) }\end{array}$ & $\begin{array}{l}\text { Percentage } \\
\text { change }\end{array}$ & $95 \% \mathrm{CI}$ & $p$ value \\
\hline \multicolumn{4}{|l|}{ Greenness: } \\
\hline 5000 m buffer, $+22 \%$ & $-10.04 \%$ & -15.2 to $-4.5 \%$ & 0.001 \\
\hline $4000 \mathrm{~m}$ buffer, $+24 \%$ & $-9.64 \%$ & -14.9 to $-4.1 \%$ & 0.002 \\
\hline 3000 m buffer,$+31 \%$ & $-10.47 \%$ & -16.6 to $-3.9 \%$ & 0.004 \\
\hline 2000 m buffer, $+38 \%$ & $-10.41 \%$ & -17.4 to $-2.9 \%$ & 0.01 \\
\hline 1000 m buffer, + 44\% & $-11.25 \%$ & -18.8 to $-3.0 \%$ & 0.01 \\
\hline 500 m buffer, $+45 \%$ & $-9.50 \%$ & -17.2 to $-1.1 \%$ & 0.03 \\
\hline $300 \mathrm{~m}$ buffer, $+44 \%$ & $-7.34 \%$ & -14.9 to $0.8 \%$ & 0.08 \\
\hline $100 \mathrm{~m}$ buffer, $+29 \%$ & $-5.61 \%$ & -10.5 to $-0.4 \%$ & 0.04 \\
\hline \multicolumn{4}{|l|}{ Residential area: } \\
\hline $5000 \mathrm{~m}$ buffer, $+15 \%$ & $11.28 \%$ & 5.3 to $17.7 \%$ & 0.0005 \\
\hline 4000 m buffer, + $17 \%$ & $10.40 \%$ & 4.3 to $16.9 \%$ & 0.001 \\
\hline $3000 \mathrm{~m}$ buffer, $+21 \%$ & $11.01 \%$ & 3.9 to $18.6 \%$ & 0.003 \\
\hline $2000 \mathrm{~m}$ buffer, $+23 \%$ & $8.20 \%$ & 1.5 to $15.3 \%$ & 0.02 \\
\hline 1000 m buffer, $+38 \%$ & $10.5 \%$ & 1.2 to $20.8 \%$ & 0.03 \\
\hline 500 m buffer, $+40 \%$ & $6.3 \%$ & -2.0 to $15.4 \%$ & 0.14 \\
\hline $300 \mathrm{~m}$ buffer, $+44 \%$ & $5.3 \%$ & -3.3 to $14.7 \%$ & 0.24 \\
\hline $100 \mathrm{~m}$ buffer, $+31 \%$ & $5.0 \%$ & -0.5 to $10.8 \%$ & 0.08 \\
\hline \multicolumn{4}{|l|}{ Industrial area: } \\
\hline $5000 \mathrm{~m}$ buffer, $+5 \%$ & $14.86 \%$ & 5.1 to $25.5 \%$ & 0.003 \\
\hline $4000 \mathrm{~m}$ buffer, $+6 \%$ & $13.19 \%$ & 4.0 to $23.2 \%$ & 0.006 \\
\hline $3000 \mathrm{~m}$ buffer, $+7 \%$ & $11.05 \%$ & 2.0 to $21.0 \%$ & 0.02 \\
\hline 2000 m buffer,$+8 \%$ & $5.19 \%$ & -2.9 to $14.0 \%$ & 0.22 \\
\hline 1000 m buffer, $+5 \%$ & $0.60 \%$ & -3.7 to $5.1 \%$ & 0.79 \\
\hline \multicolumn{4}{|c|}{ Normalized Difference Vegetation Index: } \\
\hline $5000 \mathrm{~m}$ buffer, +0.06 & $-6.29 \%$ & -11.7 to $-0.58 \%$ & 0.04 \\
\hline $4000 \mathrm{~m}$ buffer, +0.07 & $-5.76 \%$ & -10.9 to $-0.31 \%$ & 0.04 \\
\hline $3000 \mathrm{~m}$ buffer, +0.08 & $-5.66 \%$ & -11.1 to $0.05 \%$ & 0.06 \\
\hline $2000 \mathrm{~m}$ buffer, +0.10 & $-6.39 \%$ & -12.6 to $0.3 \%$ & 0.07 \\
\hline 1000 m buffer, + 0.10 & $-5.20 \%$ & -10.3 to $0.2 \%$ & 0.06 \\
\hline $500 \mathrm{~m}$ buffer, +0.11 & $-5.72 \%$ & -10.9 to -0.3 & 0.04 \\
\hline 250 m buffer,+0.13 & $-5.26 \%$ & -10.8 to $0.6 \%$ & 0.09 \\
\hline
\end{tabular}

Adjusted for newborn's sex, gestational age (linear and quadratic), birth weight, birth year (linear and quadratic), season of birth, zygosity-chorionicity group, maternal age, indicators of socioeconomic status (maternal education and neighborhood household income) and smoking during pregnancy. 


\section{CHAPTER 4}

\section{Lower placental telomere length may be attributed to maternal residential traffic exposure; a twin study}

Esmée M Bijnens ${ }^{1,2}$, Maurice P Zeegers ${ }^{2}$, Marij Gielen ${ }^{2}$, Michal Kicinski ${ }^{1}$, Geja J Hageman ${ }^{3}$, Daniëlle Pachen ${ }^{3}$, Catherine Derom ${ }^{4}$, Robert Vlietinck ${ }^{4}$, Tim S Nawrot ${ }^{1,5}$

1. Centre for Environmental Sciences, Hasselt University, Diepenbeek, Belgium

2. Department of Complex Genetics, NUTRIM School of Nutrition and Translational Research in Metabolism, Maastricht University, Maastricht, The Netherlands

3. Department of Toxicology, NUTRIM School of Nutrition and Translational Research in Metabolism, Maastricht University, Maastricht, The Netherlands

4. Centre of Human Genetics, University Hospitals Leuven, Leuven, Belgium D

5. Department of Public Health, Leuven University (KU Leuven), Leuven, Belgium 


\section{ABSTRACT}

High variation in telomere length between individuals is already present before birth and is as wide among newborns as in adults. Environmental exposures likely have an impact on this observation, but remain largely unidentified. We hypothesize that placental telomere length in twins is associated with residential traffic exposure, an important environmental source of free radicals that might accelerate ageing. Next, we intend to unravel the nature-nurture contribution to placental telomere length by estimating the heritability of placental telomere length.

We measured the telomere length in placental tissues of 211 twins in the East Flanders Prospective Twin Survey. Maternal traffic exposure was determined using geographic information system. Additionally, we estimated the relative importance of genetic and environmental sources of variance.

In this twin study, a variation in telomere length in the placental tissue was mainly determined by the common environment. Maternal residential proximity to a major road was associated with placental telomere length: a doubling in the distance to the nearest major road was associated with a 5.32\% (95\% CI: 1.90 to $8.86 \% ; p=0.003$ ) longer placental telomere length at birth. In addition, an interquartile increase (22\%) in maternal residential surrounding greenness (5 $\mathrm{km}$ buffer) was associated with an increase of $3.62 \%$ (95\% CI: 0.20 to $7.15 \%$; $p=0.04$ ) in placental telomere length.

In conclusion, we showed that maternal residential proximity to traffic and lower residential surrounding greenness is associated with shorter placental telomere length at birth. This may explain a significant proportion of air pollution-related adverse health outcomes starting from early-life, since shortened telomeres accelerate the progression of many diseases. 


\section{INTRODUCTION}

Telomeres consist of TTAGGG tandem repeats and cap chromosomes. ${ }^{1}$ They undergo progressive attrition in somatic cells because DNA polymerase is unable to fully replicate the ends of DNA caused by the unidirectional growth and the requirement for a primer to initiate synthesis. ${ }^{2}$ This is referred to as the endreplication problem. As a result telomeres progressively shorten in somatic cells and a mean leukocyte telomere length has been observed to diminish with age. ${ }^{3,4}$ As ageing starts before birth, not only establishing the telomere length at birth is a prerequisite, but also investigating environmental and genetic factors influencing telomere length is needed. The placenta plays a pivotal role in fetal development and functions as a barrier between fetal and maternal circulation. In utero telomere attrition is prevented by telomerase activity but as pregnancy progresses its activity in placental tissue declines making telomeres more sensitive to degradation. ${ }^{5-7}$ Maternal stress, ${ }^{8-10}$ under nutrition, ${ }^{11}$ exposure to cigarette smoke, ${ }^{12,13}$ and air pollution ${ }^{14-18}$ have been linked with fetal growth retardation, with compromised fetal cerebral development, and might be linked with early onset of insulin resistance. ${ }^{19}$ It has been suggested that telomere length underlies this fetal programming. ${ }^{19}$ For instance, exposure to maternal psychosocial stress during intrauterine life has been associated with shorter leukocyte telomere length in young adulthood. ${ }^{20}$ In adults telomere length was observed to be strongly related to the telomere length at birth, which widely varied and showed synchrony with telomere length of different organs. ${ }^{21-23}$

Ambient air pollution is considered as a global public health threat. ${ }^{24-27}$ Recent studies of maternal exposure to particulate matter (PM), a constituent of ambient air pollution, support evidence for detrimental effects of PM exposure on the health of fetuses 15,17 and neonates, ${ }^{28,29}$ and has been associated with cardiovascular morbidity and mortality later in life. ${ }^{24,30,31}$ Oxidative stress and inflammation are mechanisms linking exposure to particulate air pollution with premature ageing. ${ }^{32,33}$ Accelerated shortening of telomeres is an important pathway by which oxidative stress may accelerate biological ageing and agerelated diseases. ${ }^{34,35}$ In adults shorter telomere length has been linked with long-term exposure to traffic. Hoxha et al. (2009) reported lower leukocyte 
telomere length in traffic officers compared to office workers and an inverse association between telomere length and occupational exposures to benzene and toluene. ${ }^{36}$ The Veteran study reported faster telomere attrition in 70-year olds with long-term exposures to airborne particles, especially those related to traffic exposure. ${ }^{37}$ The effect size for an interquartile range (IQR) increase in black carbon was equivalent to a 3.04 year increase in age on telomere attrition. However, the effect of prenatal traffic exposure on the telomere length in the placenta is unknown. Although there is a synchrony in length among tissues of the human fetus, significant variations in telomere length among fetuses have been observed. ${ }^{22}$ This variation was also found at birth and the variation among newborns appears to be as wide as the variation in adults. ${ }^{21}$ This variation may be the result of both genetic and environmental factors. Indeed, based on twin studies $3,38,39$ and familial studies, ${ }^{40}$ telomere length has been shown to have genetic determinants. A recent meta-analysis combining estimates of six independent studies reported a heritability coefficient for leukocyte telomere length of 0.70 in adults (95\% CI $0.64-0.76) .{ }^{41}$ However, until now it is largely unknown to what extent genetic versus environmental factors exert their effect in utero and attribute to the variation in telomere length at birth.

As telomere attrition already starts before birth, we examined the association of placental telomere length in twins and residential traffic exposure, an important environmental source of free radicals that might accelerate ageing. ${ }^{42}$ Next, we intend to unravel the nature-nurture contribution to placental telomere length by estimating the heritability of placental telomere length.

\section{MATERIALS AND METHODS}

\section{Subjects}

The East Flanders Prospective Twin Survey (EFPTS) was initiated in 1964 and is a population based register of multiple births in the province of East Flanders (Belgium). We selected 231 twins of Caucasian origin (99\% naturally conceived), born between 1975 and 1982, who participated in a prenatal 
programming study. ${ }^{43}$ We excluded twins with bad or doubtful DNA quality ( $\mathrm{n}=$ $13)$, or no information on maternal residential address $(n=7)$.

\section{Zygosity determination and tissue sampling}

A trained midwife examined the placentas within $24 \mathrm{~h}$ after delivery following a standardized protocol. ${ }^{44}$ Fetal membranes were dissected, and after removing the membranes and blood clots, the fresh unfixed placentas were weighed, and their length and thickness were measured. A blood sample was taken from the umbilical cord if the blood groups of the twins had not yet been determined. An obstetrician examined placentas with obvious or suspected abnormalities. Placental biopsies were taken near the insertions of the umbilical cord and stored at $-20^{\circ} \mathrm{C}$ at a biobank.

Zygosity was determined by sequential analysis based on sex, chorion type, umbilical cord blood groups, placental alkaline phosphatase, and, since 1982, DNA fingerprints. ${ }^{45}$ After DNA-fingerprinting, a zygosity probability of 0.999 was reached.

\section{Data collection}

Data recorded by the obstetrician at birth included gestational age, birth weight, sex of the twins and parental ages. Gestational age was based on the last menstruation and was calculated as the number of completed weeks of pregnancy.

When the twins were at adult age, the parents of the twins filled out questionnaires. Maternal smoking during pregnancy and parental education were collected retrospectively in this way. Educational level as a proxy of socio economic status (SES) was categorized into three groups according to the Belgian education system; no education or primary school, lower secondary education, and higher secondary education and tertiary education. In addition to individual SES data, we gathered information on neighborhood SES. All mothers were assigned to statistical sectors (average area $=1.55 \mathrm{~km}^{2}$ ), the smallest administrative entity for which statistical data are produced by the Belgian 
National Institute of Statistics, based on their home address. Belgian census data (FOD Economie/DG Statistiek) derived from the NIS were used to define neighborhood SES based on annual household income (1994).

\section{Telomere length assay}

DNA was isolated from placental tissue using the QIAamp DNeasy blood and tissue kit (Qiagen, Venlo, The Netherlands), following the instructions of the manufacturer for animal tissues. Telomere length was determined using a monochrome multiplex quantitative PCR (Q-PCR) method. ${ }^{46}$ For multiplex QPCR, the telomere primer pair telg and telc (final concentrations of $900 \mathrm{mM}$ ) were combined with the beta-globin primer pair hbgu and hbgd (final concentrations of $500 \mathrm{mM}$ each). Reference genomic DNA (Hela 229 cell line) was used to generate two standard curves for each PCR plate, one for the telomere signal and one for the single copy gene signal. Reference samples with known telomere length, i.e. 5.5 kB (Hela S3 cell line) and 14.5 kB (Hela 229 cell line), were included into each run to enable estimation of telomere length in kB. Samples were assayed in triplicate and the average was used. Based on the reference samples the coefficient of variation was calculated to be $2.5 \%$ for within plate measurements and $4.9 \%$ for measurements between plates. Quality and concentration of the isolated placental DNA were assessed using the Nanodrop 1000 spectrophotometer (Isogen Life Science, Belgium). Due to a low DNA yield or to absorption ratios for A260/A280 that were outside the range of 1.8-2.0, 19 twin pairs were excluded from the analyses.

\section{Traffic related exposure and land use data}

Residential addresses of the mothers at birth were geocoded. Distances to the nearest major road with traffic counts available and traffic density were determined using the geographic information system (GIS) functions. All GIS analyses were conducted in ArcGIS 9.3. We collected information on two indicators of traffic at the residence: distance to major road, and traffic density. Traffic density in a buffer was equal to the length of each road in a buffer multiplied with the traffic count on each specific road. This was calculated for a $200 \mathrm{~m}$ buffer in steps of $10 \mathrm{~m}$. Traffic counts of the years 2000-2010 were 
obtained from 'Verkeerscentrum Vlaanderen, Department Mobilteit en Openbare werken'. Pearson et al. (2000) compared traffic densities with an eleven year difference. ${ }^{47}$ They observed an increase in traffic over time but the densities stay highly correlated. Streets with low traffic-carrying capacity codes without traffic measurements were assigned a default traffic count of 543 vehicles per $24 \mathrm{~h}$.

Airborne exhaust pollution from motor vehicles has high concentrations near roads and declines farther away in approximate Gaussian distribution. ${ }^{47}$ Traffic densities within a buffer were multiplied by a weight decreasing with distance, following a Gaussian curve. This model was originally developed and applied by Pearson et al. (2000) and was based on a Gaussian probability distribution assuming $96 \%$ of all motor vehicle exhaust pollutants disperse at $152.4 \mathrm{~m} .{ }^{47-50}$ Finally the sum was made for the distance-weighted traffic densities in all buffers within $200 \mathrm{~m}$. This was also repeated for 50,100 and $150 \mathrm{~m}$ buffers.

Semi-natural and forested -, agricultural -, residential and industrial areas in a $5000 \mathrm{~m}$ radius from the residential address were estimated based on Corine land cover 2000 (European Environment Agency). This was repeated for 3000 and $4000 \mathrm{~m}$ buffers.

\section{Statistical analysis}

For data management and statistical analyses, we used SAS software, version 9.1 (SAS Institute, Cary, NC). All reported $\mathrm{p}$-values are two-sided and were considered statistically significant when $\mathrm{p} \leq$ 0.05. The distribution of all quantitative variables was visually inspected in QQ-plots. Telomere length (kbp) and the traffic indicators were log-transformed to assure normality.

To investigate the association between telomere length and traffic exposure mixed modeling was performed. The twins were analyzed as individuals in a multilevel regression analysis to account for relatedness between twin members by adding a random intercept to the model. The variance-covariance structure was allowed to differ between the three zygosity-chorionicity groups including dizygotic dichorionic, monozygotic dichorionic, monozygotic monochorionic. 
Covariates were selected a priori including newborn's sex, gestational age, birth weight, birth year (linear and quadratic), zygosity and chorionicity, maternal age, indicators of socioeconomic status (maternal education and neighborhood household income) and smoking during pregnancy.

Additionally, we dichotomized a major road distance according to the distance to the nearest major road. The mean telomere length adjusted for covariates was compared between mothers living in the lowest tertile $(252 \mathrm{~m})$ and were compared with mothers living farther away than $252 \mathrm{~m}$.

Next, structural equation modeling was performed with Open Mx software ${ }^{51}$ in complete pairs (162 twins) with the significant traffic exposures from the regression analyses to estimate the genetic and environmental components of variance of the traits. The variance was decomposed in additive genetic (A), common environmental (C), and unique environmental (E) effects. This is the classic ACE model. ${ }^{52}$ The model makes use of the fact that MZ twins are genetically identical, whereas $D Z$ twins share half of their genes. Furthermore the model assumes that $M Z$ and $D Z$ twins share their common environment to the same extent. The result of this assumption is that a greater within-pair similarity in $M Z$ twins than in DZ twins reflects genetic influences. Structural equation modeling also offers the quantification of the variance components $A, C$ and $\mathrm{E}$ and the correction for covariates in the means model.

With regard to structural equation modeling the appropriate assumptions were checked first and shown to be satisfactory; there were no significant differences in the means or variances of telomere length between twin 1 and twin 2 in MZ and DZ twins.

Additionally, to test whether genetic and environmental factors influenced a trait to the same degree in monochorial and dichorial twins, we compared a heterogeneity model (variance components free to differ across different chorion types) with a homogeneity model (variance components equal for different chorion types). ${ }^{53}$ Since, no differences were observed we continued working with the homogeneity model. 
The significance of the components in the model was tested by dropping these parameters and comparing the fit of the models by use of a maximum-likelihood approach with accompanying Akaike's information criterion (AIC). The model with the lowest Akaike's information criterion was preferred. In addition, the difference in fit between the models was evaluated with the likelihood ratio chisquare test, which uses the difference between the -2 log likelihood of the full and the restricted model.

The analyses were performed six times: first (1) the unadjusted telomere length and (2) placental telomere length adjusted for previous mentioned covariates in the means model. Next we adjusted (3) for a traffic variable, distance to a major road and (4) for distance to a major road and covariates. Additionally, the analyses were also performed (5) adjusted for covariates and a land use variable; semi-natural -, forested - and agricultural areas in a buffer of $5000 \mathrm{~m}$ and (6) for this land use variable and covariates.

\section{RESULTS}

\section{Characteristics of the study population}

Table 1 summarizes the characteristics of the 130 mothers and the 211 twins. Maternal age averaged 27.5 years and ranged from 19 to 40 years. Of the mothers, $12.3 \%(n=15)$ smoked during pregnancy, and $51.6 \%(n=63)$ had ever smoked. The newborn population, including 122 girls $(53.1 \%)$ had a mean gestational age of 37.3 weeks (range 28-42). Birth weight averaged ( \pm SD) $2582 \pm 476 \mathrm{~g}$. We observed $128(60.7 \%)$ monozygotic twins and $83(39.3 \%)$ dizygotic twins. In $76.8 \%(n=162)$ of the newborns both twins participated and in $23.2 \%(n=49)$ only one twin participated. Placental telomere length $( \pm S D)$ was $13.0 \pm 8.2 \mathrm{kbp}$, the minimum was $5.9 \mathrm{kbp}$ and the maximum was $84.4 \mathrm{kbp}$. Table 2 contains the distribution of the traffic indicators. The exposure variables were all significantly correlated. The average distance from the participant's home address to the nearest road was $420 \mathrm{~m}(\mathrm{IQR}=209-1169 \mathrm{~m})$. Dividing the twins in two groups resulted in 68 twins (32.2\%) living within $252 \mathrm{~m}$ (lowest tertile) of a major road and 143 twins (68.8\%) living farther away. The average number of kilometres travelled by all vehicles in a $150 \mathrm{~m}$ buffer around the 
resident in one day equalled to 184 vehicles*km (IQR $=97-279$ vehicles*km). The average land use in percentiles in a $5000 \mathrm{~m}$ buffer was $1 \%$ industrial area $(\mathrm{IQR}=1-6 \%), 29 \%$ residential area $(\mathrm{IQR}=23-38 \%)$ and $52 \%$ combination of semi-natural -, forested - and agricultural area (IQR $=47-69 \%)$.

Table 1 Study population characteristics

\begin{tabular}{|c|c|c|c|}
\hline Characteristic & Monozygotic twins & Dizygotic twins & P-value \\
\hline Maternal & $(n=82)$ & $(n=48)$ & \\
\hline Maternal Age (years) & $27.2 \pm 4.1$ & $27.9 \pm 4.2$ & 0.39 \\
\hline$<20$ & $2(2.6)$ & $0(0)$ & 0.50 \\
\hline $20-29$ & $58(74.4)$ & $31(66.0)$ & \\
\hline $30-35$ & $16(20.5)$ & $14(29.8)$ & \\
\hline$>35$ & $2(2.6)$ & $2(4.3)$ & \\
\hline \multicolumn{4}{|l|}{ Socioeconomic status: } \\
\hline \multicolumn{4}{|l|}{ Maternal education } \\
\hline Low & $35(42.7)$ & $17(35.4)$ & 0.46 \\
\hline Middle & $15(18.3)$ & $13(27.1)$ & \\
\hline High & $32(39.0)$ & $18(37.5)$ & \\
\hline Neighborhood income (euro) & $19,505 \pm 4,503$ & $18,805 \pm 3,843$ & 0.37 \\
\hline \multicolumn{4}{|l|}{ Smoking } \\
\hline Never & $44(57.9)$ & $19(41.3)$ & 0.18 \\
\hline Before pregnancy & $23(30.3)$ & $21(45.7)$ & \\
\hline Before and during pregnancy & $9(11.8)$ & $6(13.0)$ & \\
\hline Newborn & $(n=128)$ & $(n=83)$ & \\
\hline Gestational age (weeks) & $37.2 \pm 2.5$ & $37.4 \pm 2.2$ & 0.52 \\
\hline \multicolumn{4}{|l|}{ Sex } \\
\hline Male-Male & $59(46.1)$ & $32(38.6)$ & $<0.01$ \\
\hline Female-Female & $69(53.9)$ & $35(42.2)$ & \\
\hline Male-Female & $0(0.0)$ & $16(19.3)$ & \\
\hline \multicolumn{4}{|l|}{ Chorion type } \\
\hline Monochorial & $60(46.9)$ & $0(0.0)$ & $<0.01$ \\
\hline Dichorial & $68(53.1)$ & $83(100)$ & \\
\hline \multicolumn{4}{|l|}{ Complete-pair in final study } \\
\hline One twin & $36(28.1)$ & $13(15.7)$ & 0.05 \\
\hline Both twins & $92(71.9)$ & $70(84.3)$ & \\
\hline Neonate birth weight $(\mathrm{g})$ & $2582 \pm 505$ & $2582 \pm 433$ & 0.99 \\
\hline Twin birth year & $1978 \pm 1.9$ & $1978 \pm 2.0$ & 0.86 \\
\hline Telomere length (kbp) & $12.7 \pm 6.7$ & $13.5 \pm 10.1$ & 0.52 \\
\hline
\end{tabular}

Data presented are means \pm standard deviation or number (percentage) 
Table 2 Distribution of the traffic and land use indicators

Percentile

\begin{tabular}{|c|c|c|c|c|c|c|}
\hline Traffic indicator & $\begin{array}{l}\text { Geometric } \\
\text { mean }\end{array}$ & $5^{\text {th }}$ & $25^{\text {th }}$ & $50^{\text {th }}$ & $75^{\text {th }}$ & $95^{\text {th }}$ \\
\hline Distance to major road, $\mathrm{m}$ & 420 & 29 & 209 & 424 & 1169 & 2989 \\
\hline $\begin{array}{l}\text { Distance-weighted traffic density: } \\
50 \mathrm{~m} \text { buffer, vehicles*km /day }\end{array}$ & 62 & 0 & 31 & 42 & 66 & 628 \\
\hline $\begin{array}{l}\text { Distance-weighted traffic density: } \\
100 \mathrm{~m} \text { buffer, vehicles*km /day }\end{array}$ & 134 & 38 & 68 & 96 & 158 & 1407 \\
\hline $\begin{array}{l}\text { Distance-weighted traffic density: } \\
150 \text { m buffer, vehicles*km /day }\end{array}$ & 184 & 46 & 97 & 130 & 279 & 1793 \\
\hline $\begin{array}{l}\text { Distance-weighted traffic density: } \\
200 \text { m buffer, vehicles*km /day }\end{array}$ & 194 & 48 & 100 & 144 & 308 & 1820 \\
\hline $\begin{array}{l}\text { Semi-natural, forested and agricultural } \\
\text { area: } 5000 \mathrm{~m} \text { buffer, \% }\end{array}$ & 52 & 21 & 47 & 63 & 69 & 78 \\
\hline $\begin{array}{l}\text { Semi-natural, forested and agricultural } \\
\text { area: } 4000 \mathrm{~m} \text { buffer, \% }\end{array}$ & 54 & 18 & 50 & 69 & 74 & 83 \\
\hline $\begin{array}{l}\text { Semi-natural, forested and agricultural } \\
\text { area: } 3000 \mathrm{~m} \text { buffer, \% }\end{array}$ & 50 & 11 & 42 & 66 & 74 & 82 \\
\hline Residential area: $5000 \mathrm{~m}$ buffer, $\%$ & 29 & 14 & 23 & 28 & 38 & 59 \\
\hline Residential area: $4000 \mathrm{~m}$ buffer, $\%$ & 29 & 14 & 23 & 28 & 40 & 63 \\
\hline Residential area: $3000 \mathrm{~m}$ buffer, $\%$ & 32 & 16 & 24 & 30 & 45 & 68 \\
\hline Industrial area: $5000 \mathrm{~m}$ buffer, $\%$ & 2.29 & 0 & 1.18 & 2.98 & 6.38 & 8.95 \\
\hline Industrial area: $4000 \mathrm{~m}$ buffer, $\%$ & 3.16 & 0 & 0.80 & 3.41 & 7.19 & 11.58 \\
\hline Industrial area: 3000 m buffer, \% & 4.01 & 0 & 0 & 2.86 & 7.60 & 13.47 \\
\hline
\end{tabular}

\section{Placental telomere length in association with traffic exposure}

Placental telomere length correlated inversely with residential proximity to the nearest major road before (figure 1) and after adjustment (Table 3) for newborn's sex, gestational age, birth weight, birth year (linear and quadratic), zygosity and chorionicity, maternal age, indicators of socioeconomic status (maternal education and neighborhood household income) and smoking during 
pregnancy. Mothers living close (first tertile: $<252 \mathrm{~m}$ ) had 14\% (95\% CI: 1\%$24 \%$ ) lower placental telomere length compared with those living further away ( $\geq 252 \mathrm{~m}$ ). This percentage decrease corresponds to an absolute decrease of placental telomere length of $1.82 \mathrm{kbp}$ ( $95 \% \mathrm{CI}$ : $0.14 \mathrm{kbp}$ to $3.12 \mathrm{kbp} ; \mathrm{p}=0.03$ ).

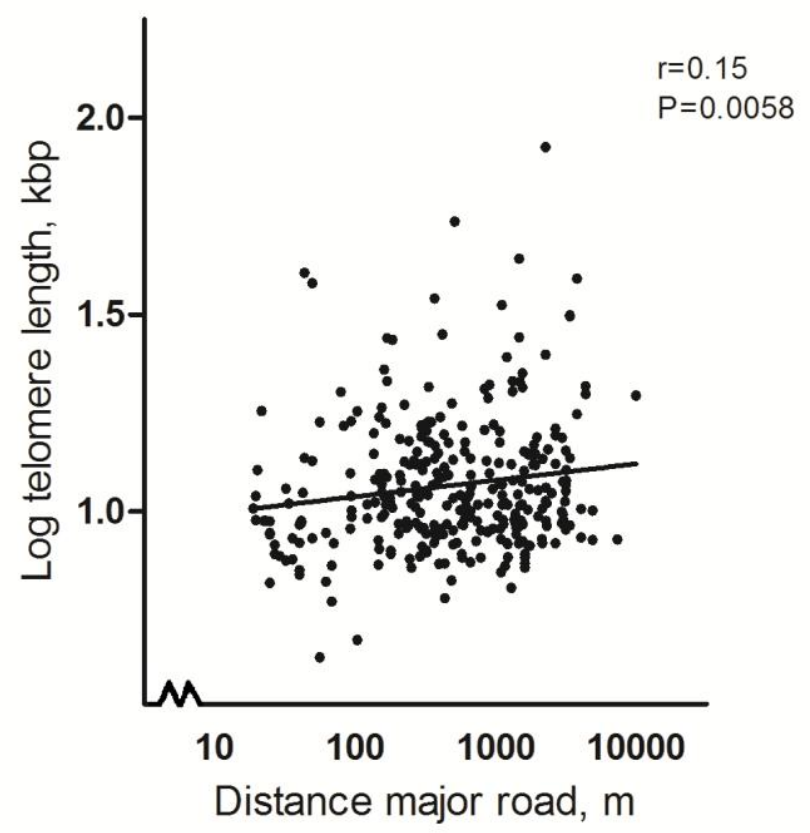

Figure 1 Placental telomere length $(\log )$ in association with distance to major road.

A doubling of the residential proximity to major road was associated with an increase of $5.32 \%(95 \% \mathrm{CI}: 1.90,8.86 \%, \mathrm{p}=0.003)$ in placental telomere length (Table 3). Increased traffic density was associated with a decreased placental telomere length, especially in a small radius from the home. A doubling in distance-weighted traffic density within a $50 \mathrm{~m}$ maternal residential radius tended to be associated with a decrease in placental telomere length of $3.97 \%$ (95\% CI: $-7.63,-0.17, p=0.04)$. A similar trend was observed in a 150 and 200 $\mathrm{m}$ buffer. 
Table 3 Estimated difference in percentage log telomere length

\begin{tabular}{|c|c|c|c|}
\hline & $\begin{array}{c}\text { Percentage } \\
\text { change }\end{array}$ & $95 \% \mathrm{CI}$ & $\begin{array}{c}\text { P- } \\
\text { value }\end{array}$ \\
\hline \multicolumn{4}{|l|}{ Traffic indicators (2-fold change) } \\
\hline Distance to major road, $\log \mathrm{m}$ & $5.32 \%$ & 1.90 to $8.86 \%$ & 0.003 \\
\hline $\begin{array}{l}\text { Distance-weighted traffic density in } 50 \mathrm{~m} \text { buffer, } \\
\text { log vehicles*km /day }\end{array}$ & $-3.97 \%$ & -7.63 to $-0.17 \%$ & 0.04 \\
\hline $\begin{array}{l}\text { Distance-weighted traffic density in } 100 \text { m buffer, } \\
\text { log vehicles*km /day }\end{array}$ & $-3.78 \%$ & -7.42 to $0.009 \%$ & 0.05 \\
\hline $\begin{array}{l}\text { Distance-weighted traffic density in } 150 \text { m buffer, } \\
\text { log vehicles*km /day }\end{array}$ & $-3.34 \%$ & -7.21 to $0.68 \%$ & 0.11 \\
\hline $\begin{array}{l}\text { Distance-weighted traffic density in } 200 \text { m buffer, } \\
\text { log vehicles*km /day }\end{array}$ & $-3.39 \%$ & -7.28 to $0.67 \%$ & 0.11 \\
\hline \multicolumn{4}{|l|}{ Dichotomized traffic indicators (2th and 3th tertile) } \\
\hline Distance to major road ( $\geq 252 \mathrm{~m}$ ) & $14 \%$ & 1 to $24 \%$ & 0.03 \\
\hline \multicolumn{4}{|l|}{ Land use indicators (increase in IQR) } \\
\hline $\begin{array}{l}\text { Semi-natural, forested and agricultural area: } \\
5000 \text { m buffer },+22 \%\end{array}$ & $3.62 \%$ & 0.20 to $7.15 \%$ & 0.04 \\
\hline $4000 \mathrm{~m}$ buffer, $+24 \%$ & $3.23 \%$ & -0.03 to $6.59 \%$ & 0.06 \\
\hline 3000 m buffer, $+31 \%$ & $3.09 \%$ & -0.70 to $7.03 \%$ & 0.12 \\
\hline Residential area: 5000 m buffer, + $15 \%$ & $-3.41 \%$ & -6.35 to $-0.38 \%$ & 0.03 \\
\hline $4000 \mathrm{~m}$ buffer, $+17 \%$ & $-3.08 \%$ & -6.02 to $-0.05 \%$ & 0.05 \\
\hline 3000 m buffer, $+21 \%$ & $-3.15 \%$ & -6.54 to $0.36 \%$ & 0.08 \\
\hline Industrial area: 5000 m buffer, $+5 \%$ & $-4.90 \%$ & -9.35 to $-0.22 \%$ & 0.04 \\
\hline 4000 m buffer, $+6 \%$ & $-3.67 \%$ & -8.01 to $0.88 \%$ & 0.12 \\
\hline 3000 m buffer, $+8 \%$ & $-1.52 \%$ & -5.88 to $3.05 \%$ & 0.51 \\
\hline
\end{tabular}

Adjusted for newborn's sex, gestational age, birth weight, birth year (linear and quadratic), zygosity and chorionicity, maternal age, indicators of socioeconomic status (maternal education and neighborhood household income) and smoking during pregnancy.

\section{Placental telomere length and land use indicators}

The effect of land use indicators appeared to be significant at a larger radius than the effect of residential traffic. Residential area in a $5000 \mathrm{~m}$ buffer had a significant inverse association with placental telomere length: for each IQR 
(15\%) increase in area there was a $3.41 \%$ decrease in telomere length (95\% $\mathrm{CI}: 6.35,-0.38 \%, \mathrm{p}=0.03)$. A $3.62 \%$ significant increase in telomere length (95\% CI: $0.20,7.15 \%, p=0.04)$ was observed with an IQR (22\%) increase in natural and agricultural areas in a $5000 \mathrm{~m}$ buffer (residential surrounding greenness). A decrease in telomere length of $4.90 \%$ (95\% CI:-9.35, $-0.22 \%$, $\mathrm{p}=0.04$ ) was observed for an IQR (5\%) increase in industrial area in a $5000 \mathrm{~m}$ buffer.

\section{Placental telomere length variation and its variation by genetic versus environmental factors}

For the variation in placental telomere length we did not find evidence for a genetic component, whereas common environmental sources accounted for $62 \%$ (95\% CI: $47,74 \%$ ) of the variance in the best-fitting (CE) model (Table 4). The fit of the ACE model in which the variance is decomposed into a genetic, common environment and unique environment was significantly better than the $A E$ model (genetic and unique environment variance).

The common environmental source explained 57\% (95\% CI: 40, 70\%) after adjusting for the covariables; newborn's sex, gestational age, birth weight, birth year (linear and quadratic), zygosity and chorionicity, maternal age, indicators of socioeconomic status (maternal education and neighborhood household income) and smoking during pregnancy. After adjusting for distance to a major road and the previously mentioned covariates, the CE model remained the bestfitting model with common environmental sources explaining 55\% (95\% CI: 37, $68 \%)$.

Adjusting for semi-natural, forested and agricultural areas in a $5000 \mathrm{~m}$ buffer and other covariates resulted in similar results for the CE model as a best-fitting model. The common environment accounted for 56\% (95\% CI: 39, 70\%) of the total variance of placental telomere length. 
Table 4 Variance components estimates of placental telomere length

\begin{tabular}{|c|c|c|c|c|c|}
\hline & \multicolumn{3}{|c|}{ Variance components } & \multicolumn{2}{|c|}{ Model fit } \\
\hline & $a^{2}$ & $c^{2}$ & $e^{2}$ & AIC & $\begin{array}{c}P \\
(\Delta-2 \mathrm{LL})\end{array}$ \\
\hline \multicolumn{6}{|c|}{ a) unadjusted } \\
\hline ACE & $0.07(0.00,0.57)$ & $0.57(0.11,0.74)$ & $0.36(0.23,0.53)$ & -432 & - \\
\hline CE & - & $0.62(0.47,0.74)$ & $0.38(0.26,0.53)$ & -434 & 0.78 \\
\hline$A E$ & $0.67(0.51,0.77)$ & - & $0.33(0.21,0.49)$ & -428 & 0.018 \\
\hline \multicolumn{6}{|c|}{ b) adjusted for distance to major road + covariates } \\
\hline ACE & $0.13(0.00,0.69)$ & $0.45(0.00,0.68)$ & $0.42(0.27,0.62)$ & -428 & - \\
\hline $\mathrm{CE}$ & - & $0.55(0.37,0.68)$ & $0.45(0.32,0.63)$ & -430 & 0.64 \\
\hline$A E$ & $0.61(0.42,0.74)$ & - & $0.39(0.26,0.58)$ & -428 & 0.11 \\
\hline
\end{tabular}

Given is the proportion of unexplained variance for additive genetic (a2), common environmental (c2), and unique environmental factors (e2); ACE is a model that contained additive genetic, common environmental, and unique environmental factors; $A E$ is a model that contained additive genetic and unique environmental factors; CE is a model that contained common environmental and unique environmental factors. Structural equation modelling was a) unadjusted, b) adjusted for distance to major road + covariates in the means model (newborn's sex, gestational age, birth weight birth year (linear and quadratic), zygosity and chorionicity, maternal age, socioeconomic status (maternal education and neighborhood household income) and smoking during pregnancy); AIC, Akaike's information criterion; -2LL, -2 log likelihood.

\section{DISCUSSION}

Among 211 twins from the East Flanders Prospective Twin Study, we investigated the association between traffic exposure and placental telomere length. We observed that maternal residential proximity to major roads was associated with a lower placental telomere length. A doubling in residential distance to a major road was associated with a $5.32 \%$ increase (95\% CI: 1.90 , $8.86 \%, p=0.003)$ in placental telomere length. In addition, the percentage of surrounding greenness within $5 \mathrm{~km}$ of maternal residence was positively associated with placental telomere length. These associations could not be explained by newborn age, gestational age, birth weight, birth year (linear and 
quadratic), zygosity and chorionicity, maternal age, indicators of socioeconomic status (maternal education and neighborhood household income) and smoking during pregnancy. In addition genetic factors appeared to play a minor role in placental telomere length.

The present study has some limitations. The twins were born from 1975 till 1982 and the traffic counts are dated from 2010. Pearson et al. (2000) compared traffic densities with a 11 year difference and observed an increase in traffic over time but the densities stayed highly correlated. ${ }^{47}$ The land-use data were dated from 2000. Similar results were obtained with land-use data from 2006. No earlier satellite data on land-use were available. Therefore, it is unlikely that our results lower placental telomere length in association with distance to a major road, and maternal residential green space is not influenced by potential time dependent exposure misclassification. Our associations between placental telomere length and traffic and residential greenness were independent of socioeconomic indicators as exemplified by maternal education at the individual level and by group level neighborhood household income did not alter our reported associations.

Our observations of a reduced placental telomere length in association with traffic exposure in utero are consistent with other studies in adult populations that found an inverse relation between traffic exposure and telomere length. $36,37,54$ The unifying thread for shorter placental telomere length and traffic related exposures in utero is likely to be oxidative stress. Oxidative stress is central to the ageing process ${ }^{55,56}$ and it may accelerate the rate of telomere erosion per replicative cycle. ${ }^{33}$ Indeed, telomeres are highly sensitive to oxidative stress induced DNA damage as a result of their high guanine content. ${ }^{57}$ In addition, single strand breaks produced by reactive oxygen species have a high frequency in telomeric DNA due to an inefficient repair of these breaks. In this manner oxidative damage can accumulate. ${ }^{58}$ Telomeres in placental tissue are most vulnerable at the end of gestation. In the beginning of gestation telomerase activity is high but this activity declines during pregnancy. ${ }^{5,6}$ To this end, placental telomere length may reflect the cumulative oxidative stress burden over in utero life. Inhalation of fine or coarse particles induced an 
inflammatory response in the lungs of mice. ${ }^{59}$ This particle induced inflammation leads to the activation of alveolar macrophages to produce ROS and resulting in oxidative stress. ${ }^{32,42}$ In addition to lung inflammation, traffic related particles of the smallest fraction were observed to translocate into the circulation. ${ }^{60}$ The blood circulation of the mother can transport these particles to the placenta and particles with a diameter of less than $240 \mathrm{~nm}$ are able to cross the transplacental barrier. ${ }^{61}$ It has been suggested that an adaptive response in the fetus to in utero exposures could result in persistent changes that influence health later in life. ${ }^{11}$ Recently, it has been shown that maternal exposure to residential traffic was associated with mitochondrial damage, as exemplified by lower placental mtDNA content. ${ }^{62}$ The mtDNA damage reflects oxidative stress production and induces mtDNA replication as a compensatory mechanism resulting in a vicious circle of more ROS formation from defective mitochondria. ${ }^{62}$ Additionally, exposure to particulate air pollution in early pregnancy has been associated with a lower degree of global DNA methylation of placental tissue. ${ }^{63}$ Besides an effect on placental DNA, elevated frequencies of DNA deletions were observed in offspring as a result of maternal exposure to diesel exhaust particles during gestation. The authors believed that a direct particle effect was not present but that it was more likely that the deletions arose from transplacental transport of released constituents of the particles into the bloodstream of the embryo. ${ }^{32}$

The public health significance of shorter telomere length at birth can be illustrated by the fact that telomere length at birth is an important predictor for telomere length in adulthood. ${ }^{23}$ We showed that placental telomere length was $1.82 \mathrm{kbp}(95 \% \mathrm{CI}: 0.14,3.12 \% ; \mathrm{p}=0.03$ ) shorter in mothers who lived within $252 \mathrm{~m}$ of a major road (lowest tertile) than those living farther away. The telomere length among multiple organs of the human fetus has been reported to be synchronized. ${ }^{21}$ Given that synchronization in telomere length among multiple organs including placenta of the human fetus exists, the observed effect is very strong compared with shortening of leukocyte telomere length in adults (telomere attrition rate of $0.024 \mathrm{~kb} /$ year). ${ }^{64}$ This effect seems to be unrealistic but fits with observations in early-life showing a rapid decline in average telomere length from birth through about an age of 4 years after which it 
remained stable until early adulthood. ${ }^{65}$ The effects of environmental exposures on telomere length may be more pronounced in this period due to the larger number of cell divisions. In other words, the early-life effects observed appear very large compared with the environmental influences contrasted later in life and might attribute to the significant difference in telomere length between newborns. Epidemiologic studies have shown that women residing close to major roadways have increased odds of adverse birth outcomes including low birth weight, preterm birth and small for gestational age. ${ }^{14,16,66-71}$ This is in line with reports on newborns complicated with fetal growth restriction who had lower placental telomere length and reduced levels of placental telomerase activity -an enzyme responsible for completing replication of telomeric DNA during cell divisions- at birth compared to their full grown counterparts. ${ }^{72-74}$ The proportion of observed variation in placental telomere length that can be attributed to inherited genetic factors in contrast to environmental ones was low in this study. We did not expect such a low contribution of genetic factors in explaining the variation as this is in contrast to the observations of leukocyte telomere length. ${ }^{41}$ We assume that the low explained variance of placental telomere length by genetic factors might be due to a relatively large variation of common environmental factors influencing telomere length during in utero life, compared to a low genetic variation, which would consequently result in a low heritability.

\section{CONCLUSIONS}

To summarize, we showed for the first time that traffic related exposures and lower maternal residential greenness surrounding access during pregnancy may be a risk factor for shorter placental telomere length at birth. Moreover, genetic factors appear to be of minor importance since telomere length in placental tissue is mainly determined by the common environment. The consequences of environmentally induced shorter placental telomere length for health in later life should be further elucidated but it might be a relevant pathway for air pollutionrelated adverse health outcomes and its developmental origin. 


\section{FUNDING}

The project is supported from the EU programme "ENVIRONAGE" (ERC-2012StG 310890), Flemish Scientific fund (G087311N10/GOA7814N/1516112N) and Bijzonder Onderzoeksfonds (tUL-funding). Michal Kicinski is a Ph.D fellow the Research Foundation-Flanders (FWO). Since its origin the East Flanders Prospective Twin Survey has been partly supported by grants from the Fund of Scientific Research, Flanders and Twins, a non-profit Association for Scientific Research in Multiple Births (Belgium). 


\section{REFERENCES}

1. Blackburn EH. Switching and signaling at the telomere. Cell. 2001;106:661-673.

2. Levy MZ, Allsopp RC, Futcher AB, Greider CW and Harley CB. Telomere end-replication problem and cell aging. Journal of molecular biology. 1992;225:951-60.

3. Slagboom PE, Droog $\mathrm{S}$ and Boomsma DI. Genetic determination of telomere size in humans: a twin study of three age groups. AmJHumGenet. 1994;55:876-882.

4. Benetos A, Okuda K, Lajemi M, Kimura M, Thomas F, Skurnick J, et al. Telomere length as an indicator of biological aging: the gender effect and relation with pulse pressure and pulse wave velocity. Hypertension. 2001;37:381-385.

5. Chen RJ, Chu CT, Huang SC, Chow SN and Hsieh CY. Telomerase activity in gestational trophoblastic disease and placental tissue from early and late human pregnancies. HumReprod. 2002;17:463-468.

6. Kyo S, Takakura M, Tanaka M, Kanaya T, Sagawa T, Kohama T, et al. Expression of telomerase activity in human chorion. BiochemBiophysResCommun. 1997;241:498-503.

7. Gielen M, Hageman G, Pachen D, Derom C, Vlietinck R and Zeegers MP. Placental telomere length decreases with gestational age and is influenced by parity: a study of third trimester live-born twins. Placenta. 2014;35:791-796.

8. Torche $F$. The effect of maternal stress on birth outcomes: exploiting a natural experiment. Demography. 2011;48:1473-1491.

9. Lee BE, Ha M, Park H, Hong YC, Kim Y, Kim YJ, et al. Psychosocial work stress during pregnancy and birthweight. PaediatrPerinatEpidemiol. 2011;25:246-254.

10. Class QA, Lichtenstein $\mathrm{P}$, Langstrom $\mathrm{N}$ and $\mathrm{D}^{\prime}$ Onofrio BM. Timing of prenatal maternal exposure to severe life events and adverse pregnancy outcomes: a population study of 2.6 million pregnancies. PsychosomMed. 2011;73:234-241.

11. Schulz LC. The Dutch Hunger Winter and the developmental origins of health and disease. ProcNatIAcadSciUSA. 2010;107:16757-16758.

12. Ko TJ, Tsai LY, Chu LC, Yeh SJ, Leung C, Chen CY, et al. Parental Smoking during Pregnancy and Its Association with Low Birth Weight, Small for Gestational Age, and Preterm Birth Offspring: A Birth Cohort Study. PediatrNeonatol. 2014;55:20-27.

13. Wahabi HA, Mandil AA, Alzeidan RA, Bahnassy AA and Fayed AA. The independent effects of second hand smoke exposure and maternal body mass index on the anthropometric measurements of the newborn. BMC Public Health. 2013;13:1058.

14. Pedersen M, Giorgis-Allemand L, Bernard C, Aguilera I, Andersen A-M, Ballester $F$, et al. Ambient air pollution and low birthweight: a European cohort study (ESCAPE). Lancet Respir Med. 2013;1:695-704.

15. Ballester F, Estarlich M, Iniguez C, Llop S, Ramon R, Esplugues A, et al. Air pollution exposure during pregnancy and reduced birth size: a prospective birth cohort study in Valencia, Spain. EnvironHealth. 2010;9:6. 
16. Brauer $M$, Lencar $C$, Tamburic $L$, Koehoorn $M$, Demers $P$ and Karr $C$. A cohort study of traffic-related air pollution impacts on birth outcomes. EnvironHealth Perspect. 2008;116:680-686.

17. Dadvand P, Parker J, Bell ML, Bonzini M, Brauer M, Darrow LA, et al. Maternal exposure to particulate air pollution and term birth weight: a multi-country evaluation of effect and heterogeneity. EnvironHealth Perspect. 2013;121:267-373.

18. Liu S, Krewski D, Shi Y, Chen $Y$ and Burnett RT. Association between gaseous ambient air pollutants and adverse pregnancy outcomes in Vancouver, Canada. EnvironHealth Perspect. 2003;111:1773-1778.

19. Entringer S, Buss C and Wadhwa PD. Prenatal stress, telomere biology, and fetal programming of health and disease risk. SciSignal. 2012;5:t12.

20. Entringer S, Epel ES, Kumsta R, Lin J, Hellhammer DH, Blackburn EH, et al. Stress exposure in intrauterine life is associated with shorter telomere length in young adulthood. ProcNatIAcadSciUSA. 2011;108:E513-E518.

21. Okuda K, Bardeguez A, Gardner JP, Rodriguez P, Ganesh V, Kimura M, et al. Telomere length in the newborn. PediatrRes. 2002;52:377-381.

22. Youngren $K$, Jeanclos $E$, Aviv $H$, Kimura $M$, Stock J, Hanna $M$, et al. Synchrony in telomere length of the human fetus. HumGenet. 1998; $102: 640-643$.

23. Heidinger BJ, Blount JD, Boner W, Griffiths $K$, Metcalfe NB and Monaghan P. Telomere length in early life predicts lifespan. Proceedings of the National Academy of Sciences of the United States of America. 2012;109:1743-8.

24. Nawrot TS, Perez L, Kunzli N, Munters E and Nemery B. Public health importance of triggers of myocardial infarction: a comparative risk assessment. Lancet. 2011;377:732-740.

25. Adar SD, Sheppard L, Vedal S, Polak JF, Sampson PD, Diez Roux AV, et al. Fine particulate air pollution and the progression of carotid intimamedial thickness: a prospective cohort study from the multi-ethnic study of atherosclerosis and air pollution. PLoS Med. 2013;10:e1001430.

26. Brunekreef $B$ and Holgate ST. Air pollution and health. Lancet. 2002;360:1233-1242.

27. Katsouyanni K, Touloumi G, Spix C, Schwartz J, Balducci F, Medina S, et al. Short-term effects of ambient sulphur dioxide and particulate matter on mortality in 12 European cities: results from time series data from the APHEA project. Air Pollution and Health: a European Approach. BMJ (Clinical research ed). 1997;314:1658-63.

28. Scheers H, Mwalili SM, Faes C, Fierens F, Nemery B and Nawrot TS. Does air pollution trigger infant mortality in Western Europe? A casecrossover study. EnvironHealth Perspect. 2011;119:1017-1022.

29. Ritz $B$, Wilhelm $M$ and Zhao $Y$. Air pollution and infant death in southern California, 1989-2000. Pediatrics. 2006;118:493-502.

30. Brook RD, Rajagopalan S, Pope CA, III, Brook JR, Bhatnagar A, DiezRoux AV, et al. Particulate matter air pollution and cardiovascular disease: An update to the scientific statement from the American Heart Association. Circulation. 2010;121:2331-2378. 
31. Grahame TJ and Schlesinger RB. Oxidative stress-induced telomeric erosion as a mechanism underlying airborne particulate matter-related cardiovascular disease. Part Fibre Toxicol. 2012;9:21.

32. Reliene R, Hlavacova A, Mahadevan B, Baird WM and Schiestl RH. Diesel exhaust particles cause increased levels of DNA deletions after transplacental exposure in mice. MutatRes. 2005;570:245-252.

33. von Zglinicki T. Role of oxidative stress in telomere length regulation and replicative senescence. AnnNYAcadSci. 2000;908:99-110.

34. Monickaraj F, Aravind S, Gokulakrishnan K, Sathishkumar C, Prabu P, Prabu $D$, et al. Accelerated aging as evidenced by increased telomere shortening and mitochondrial DNA depletion in patients with type 2 diabetes. MolCell Biochem. 2012;365:343-350.

35. Haycock PC, Heydon E, Kaptoge S, Butterworth AS, Thompson A and Willeit $P$. Leucocyte telomere length and risk of cardiovascular disease: systematic review and meta-analysis. BMJ (Clinical research ed). $2014 ; 349$.

36. Hoxha M, Dioni L, Bonzini M, Pesatori AC, Fustinoni S, Cavallo D, et al. Association between leukocyte telomere shortening and exposure to traffic pollution: a cross-sectional study on traffic officers and indoor office workers. EnvironHealth. 2009;8:41.

37. McCracken J, Baccarelli A, Hoxha M, Dioni L, Melly S, Coull B, et al. Annual ambient black carbon associated with shorter telomeres in elderly men: Veterans Affairs Normative Aging Study. EnvironHealth Perspect. 2010;118:1564-1570.

38. Andrew T, Aviv A, Falchi M, Surdulescu GL, Gardner JP, Lu X, et al. Mapping genetic loci that determine leukocyte telomere length in a large sample of unselected female sibling pairs. AmJHumGenet. 2006;78:480486.

39. Bischoff C, Graakjaer J, Petersen HC, Hjelmborg J, Vaupel JW, Bohr V, et al. The heritability of telomere length among the elderly and oldest-old. Twin ResHumGenet. 2005;8:433-439.

40. Nawrot TS, Staessen JA, Gardner JP and Aviv A. Telomere length and possible link to $X$ chromosome. Lancet. 2004;363:507-510.

41. Broer L, Codd V, Nyholt DR, Deelen J, Mangino M, Willemsen G, et al. Meta-analysis of telomere length in 19713 subjects reveals high heritability, stronger maternal inheritance and a paternal age effect. EurJHumGenet. 2013:1163-1168.

42. Iwai K, Adachi S, Takahashi M, Moller L, Udagawa T, Mizuno S, et al. Early oxidative DNA damages and late development of lung cancer in diesel exhaust-exposed rats. Environ Res. 2000;84:255-264.

43. Loos RJ, Beunen G, Fagard R, Derom C and Vlietinck R. The influence of zygosity and chorion type on fat distribution in young adult twins consequences for twin studies. Twin Res. 2001;4:356-364.

44. Derom R, Derom C and Vlietinck R. Placentation. In: K. LG, ed. Multiple pregnancy: Epidemiology, Gestation \& Perinatal outcome New York: The Parthenon Publishing Group; 1995: 113-128.

45. Vlietinck R. Determination of the zygosity of twins Leuven: Katholieke Universiteit Leuven; 1986: 1-123.

46. Cawthon RM. Telomere length measurement by a novel monochrome multiplex quantitative PCR method. Nucleic Acids Res. 2009;37:e21. 
47. Pearson $\mathrm{RL}$, Wachtel $\mathrm{H}$ and Ebi $\mathrm{KL}$. Distance-weighted traffic density in proximity to a home is a risk factor for leukemia and other childhood cancers. J Air Waste Manag Assoc. 2000;50:175-180.

48. Zhu Y, Hinds WC, Kim S and Sioutas C. Concentration and size distribution of ultrafine particles near a major highway. JAir Waste ManagAssoc. 2002;52:1032-1042.

49. Roorda-Knape MC, Janssen NAH, de Hartog JJ, Van Vliet PHN, Harssema $\mathrm{H}$ and Brunekreef $\mathrm{B}$. Air pollution from traffic in city districts near major motorways. Atmospheric Environment. 1998;32:1921-1930.

50. Hitchins J, Morawska L, Wolff R and Gilbert D. Concentrations of submicrometre particles from vehicle emissions near a major road. Atmospheric Environment. 2000;34:51-59.

51. Neale MC, Boker SM, Xie G and Maes HH. Mx: statistical modeling. 6th ed. Richmond, VA: Department of Psychiatry, Virginia Commonwealth University; 2003.

52. Neale MC and Maes HM. Methodology for Genetic Studies of Twins and Families. Dordrecht, The Netherlands: Academic Publishers B.V.; 2002.

53. Souren NY, Paulussen AD, Loos RJ, Gielen M, Beunen G, Fagard R, et al. Anthropometry, carbohydrate and lipid metabolism in the East Flanders Prospective Twin Survey: heritabilities. Diabetologia. 2007;50:21072116.

54. Hou L, Wang S, Dou C, Zhang $X, Y u$, Zheng $Y$, et al. Air pollution exposure and telomere length in highly exposed subjects in Beijing, China: a repeated-measure study. EnvironInt. 2012;48:71-77.

55. Spyridopoulos I, Haendeler J, Urbich C, Brummendorf TH, Oh $H$, Schneider MD, et al. Statins enhance migratory capacity by upregulation of the telomere repeat-binding factor TRF2 in endothelial progenitor cells. Circulation. 2004;110:3136-3142.

56. Huang $\mathrm{H}$ and Manton KG. The role of oxidative damage in mitochondria during aging: a review. Front Biosci. 2004;9:1100-1117.

57. Kawanishi S and Oikawa S. Mechanism of telomere shortening by oxidative stress. AnnNYAcadSci. 2004;1019:278-284.

58. Petersen S, Saretzki G and von ZT. Preferential accumulation of singlestranded regions in telomeres of human fibroblasts. ExpCell Res. 1998;239:152-160.

59. Li YJ, Takizawa H, Azuma A, Kohyama T, Yamauchi Y, Takahashi S, et al. Disruption of Nrf2 enhances susceptibility to airway inflammatory responses induced by low-dose diesel exhaust particles in mice. ClinImmunol. 2008;128:366-373.

60. Nemmar A, Hoet PH, Vanquickenborne B, Dinsdale D, Thomeer M, Hoylaerts MF, et al. Passage of inhaled particles into the blood circulation in humans. Circulation. 2002;105:411-414.

61. Wick P, Malek A, Manser P, Meili D, Maeder-Althaus X, Diener L, et al. Barrier capacity of human placenta for nanosized materials. EnvironHealth Perspect. 2010;118:432-436.

62. Janssen BG, Munters E, Pieters N, Smeets K, Cox B, Cuypers A, et al. Placental mitochondrial DNA content and particulate air pollution during in utero life. Environ Health Perspect. 2012;120:1346-1352. 
63. Janssen BG, Godderis L, Pieters N, Poels K, Kici SM, Cuypers A, et al. Placental DNA hypomethylation in association with particulate air pollution in early life. Part Fibre Toxicol. 2013;10:22.

64. Daniali L, Benetos A, Susser E, Kark JD, Labat C, Kimura M, et al. Telomeres shorten at equivalent rates in somatic tissues of adults. NatCommun. 2013;4:1597.

65. Frenck RW, Jr., Blackburn EH and Shannon KM. The rate of telomere sequence loss in human leukocytes varies with age. ProcNatIAcadSciUSA. 1998;95:5607-5610.

66. Miranda ML, Edwards SE, Chang $\mathrm{HH}$ and Auten RL. Proximity to roadways and pregnancy outcomes. JExpoSciEnvironEpidemiol. 2013;23:32-38.

67. Genereux M, Auger N, Goneau M and Daniel M. Neighbourhood socioeconomic status, maternal education and adverse birth outcomes among mothers living near highways. JEpidemiolCommunity Health. 2008;62:695-700.

68. Wilhelm $M$ and Ritz B. Residential proximity to traffic and adverse birth outcomes in Los Angeles county, California, 1994-1996. EnvironHealth Perspect. 2003;111:207-216.

69. Yang CY, Chang CC, Chuang HY, Ho CK, Wu TN and Tsai SS. Evidence for increased risks of preterm delivery in a population residing near a freeway in Taiwan. ArchEnvironHealth. 2003;58:649-654.

70. Zeka A, Melly SJ and Schwartz J. The effects of socioeconomic status and indices of physical environment on reduced birth weight and preterm births in Eastern Massachusetts. EnvironHealth. 2008;7:60.

71. Volk HE, Hertz-Picciotto I, Delwiche L, Lurmann F and McConnell R. Residential Proximity to Freeways and Autism in the CHARGE Study. Environmental Health Perspectives. 2011;119:873-877.

72. Biron-Shental T, Sukenik HR, Goldberg-Bittman L, Kidron D, Fejgin MD and Amiel A. Telomeres are shorter in placental trophoblasts of pregnancies complicated with intrauterine growth restriction (IUGR). Early HumDev. 2010;86:451-456.

73. Davy $P$, Nagata M, Bullard $P$, Fogelson NS and Allsopp R. Fetal growth restriction is associated with accelerated telomere shortening and increased expression of cell senescence markers in the placenta. Placenta. 2009;30:539-542.

74. Toutain J, Prochazkova-Carlotti M, Cappellen D, Jarne A, Chevret E, Ferrer J, et al. Reduced placental telomere length during pregnancies complicated by intrauterine growth restriction. PLoS One. 2013;8:e54013. 


\section{CHAPTER 5}

\section{Telomere tracking across the three first decades of life and residential traffic and greenness exposure}

\section{Esmée M Bijnens $^{1,2}$, Tim S Nawrot ${ }^{1,3}$, Catherine Derom ${ }^{4,5}$, Dries Martens ${ }^{1}$, Marij Gielen ${ }^{2}$, Geja J Hageman ${ }^{6}$, Michelle Plusquin?, Robert Vlietinck ${ }^{4}$, Maurice $P$ Zeegers ${ }^{2}$}

1. Centre for Environmental Sciences, Hasselt University, Diepenbeek, Belgium

2. Department of Complex Genetics, NUTRIM School of Nutrition and Translational Research in Metabolism, Maastricht University Medical Centre, Maastricht, The Netherlands

3. Department of Public Health, Leuven University (KU Leuven), Leuven, Belgium

4. Centre of Human Genetics, University Hospitals Leuven, Leuven, Belgium

5. Department of Obstetrics and Gynaecology, Ghent University Hospitals, Ghent, Belgium

6. Department of Toxicology, NUTRIM School of Nutrition and Translational Research in Metabolism, Maastricht University Medical Centre, Maastricht, The Netherlands

7. School of public health, Imperial College, London, United Kingdom 


\section{ABSTRACT}

Telomere attrition is extremely rapid the first years of life and lifestyle during adulthood exert only a minor impact on telomere ranking. This suggest that the early-life is an important period in the determination of telomere length. We investigated the importance of the early-life environment on both telomere tracking and adult telomere length.

Among 205 twins of the East Flanders Prospective Twin Survey, telomere length in placental tissue and in buccal cells in young adulthood was measured. Residential addresses at birth and in young adulthood were geocoded and traffic and greenness exposure was determined. The association between telomere length early and later in life was investigated and mixed modelling was performed to investigate the association between telomere length in young adulthood and the early-life environment.

We observed an association between placental telomere length and telomere length in buccal cells in young adulthood. Among twins who were living at a different address than their birth address at time of measurement adult telomere length and telomere ranking between birth and young adulthood were negatively associated with traffic exposure at the birth address. Whereas, traffic exposure at the residential address at adult age was not associated with telomere length.

Traffic related exposure in early-life is not only associated with shorter telomere length in placental tissue but also in young adulthood. As telomere length is a biomarker of ageing, these results suggest that environmental exposure in early-life may have implications for health outcome later in life. 


\section{INTRODUCTION}

Telomeres are located at the end of the chromosomes and protect these regions from degradation activities. ${ }^{1}$ Most human somatic tissues are not able to maintain telomere length and the telomeres shorten during cell division resulting in telomere attrition with age. ${ }^{2}$ Eventually the telomeres reach a critical length resulting in loss of protection and chromosomal instability. ${ }^{3}$ Defects in telomere length have been implicated in the pathology of several age-related diseases including cardiovascular disease, ${ }^{4}$ diabetes mellitus ${ }^{5}$ and cancer. ${ }^{6,7}$ Moreover, an association between telomere length and mortality is observed in studies in elderly twins showing that the twin with the shortest telomere length has a greater risk of death during follow-up than the co-twin with the longest telomeres. $^{8,9}$ This indicates that telomere length might serve as a biomarker of human ageing. ${ }^{10}$

The decline of telomere length with age has been observed in longitudinal studies starting from early adult life till advanced age. ${ }^{11-13}$ However, crosssectional studies comparing individuals with a wide age range from neonates to elderly observed that the rate of telomere attrition varied at different ages. ${ }^{14,15}$ They show in more than 500 individuals ranging in age from 0 to 90 years that telomere loss was extremely rapid in the first year and continued thereafter at a slower rate. ${ }^{15}$ In addition, a longitudinal study measuring telomere length in samples donated 12 year apart by 1,156 participants observed that in adults telomere length ranking does not change over time. ${ }^{16}$ They suggest that most of the interindividual variation in telomere length among adults is established early in life and that lifestyle during adulthood exert only a minor impact on telomere ranking. ${ }^{16}$ This indicates that the early-life is an important period in the determination of telomere length and could have a lasting effect on telomere length throughout the life course.

Shorter leukocyte telomere length was observed in traffic officers compared to office workers ${ }^{17}$ and long term exposure to airborne particles especially those related to traffic is associated with faster telomere attrition in 70 -year olds. ${ }^{18}$ In addition, we observed in previous research that maternal residential proximity to 
traffic and lower residential surrounding greenness is associated with shorter placental telomere length at birth. ${ }^{19}$ Currently, there is a lack in understanding the importance of the early-life environment on both telomere tracking and adult life telomere length. We studied the effects of traffic exposure early in life on telomere tracking over a three decade period. Our results show that exposures early in life have long term consequences and determines telomere length at adult life over and beyond later life exposure.

\section{MATERIAL AND METHODS}

\section{Subjects}

The East Flanders Prospective Twin Survey (EFPTS), a population-based register of multiple births in the province of East-Flanders (Belgium), started in 1964 to enrol twins at birth. ${ }^{20}$ The twin-population in our study was based on a previous twin study by Loos et al. (2001). From this population we could obtain 196 twins of Caucasian Belgium origin with data available on placental telomere length at birth and buccal telomere length in young adulthood. ${ }^{21}$

\section{Telomere length measurements in placental tissue}

Placental biopsies were taken close to the surface near the insertion of the umbilical cord of each twin and stored at $-20^{\circ} \mathrm{C}$ at a biobank. DNA was isolated from placental tissue using the QIAamp DNeasy blood and tissue kit (Qiagen, Venlo, The Netherlands), following the instructions of the manufacturer for animal tissues. The methods of telomere length measurements in placental tissue are described previously. ${ }^{19,22}$ In brief, telomere length was determined using a monochrome multiplex quantitative PCR (Q-PCR) method. ${ }^{23}$ For multiplex QPCR, the telomere primer pair telg and telc (final concentrations of $900 \mathrm{mM}$ ) were combined with the beta-globin primer pair hbgu and hbgd (final concentrations of $500 \mathrm{mM}$ each). Reference genomic DNA (Hela 229 cell line) was used to generate two standard curves for each PCR plate, one for the telomere signal and one for the single copy gene signal. Reference samples with known telomere length, i.e. 5.5 kB (Hela S3 cell line) and 14.5 kB (Hela 229 cell 
line), were included into each run to enable estimation of telomere length in $k B$. Samples were assayed in triplicate and the average was used.

\section{Telomere length measurements in buccal cells}

Mouth swabs were taken and DNA was extracted with the QIAamp DNA micro kit (Qiagen, Venlo, The Netherlands). DNA purity and concentration was assessed using the Nanodrop 1000 spectrophotometer (Isogen Life Science, Belgium). Relative telomere length was measured in buccal swabs using a adapted quantitative real-time polymerase chain reaction (qPCR) method. ${ }^{23}$ Relative telomere length is based on the ratio of telomere length to a single-copy nuclear control gene, $36 B 4$ (acidic ribosomal phosphoprotein P0). ${ }^{23}$ Extracted genomic DNA was diluted, resulting in a final input of $5 \mathrm{ng}$. Telomere PCR reaction mixture contained $1 X$ QuantiTect SYBR $®$ Green (Qiagen, Venlo, The Netherlands) mastermix, $300 \quad \mathrm{nM}$ primer telg (ACACTAAGGTTTGGGTTTGGGTTTGGGTTTGGGTTAG TGT) and 900nM primer telc (TGTTAGGTATCCCTATCCCTATCCCTATCCCTATCCCTAACA) and $2.5 \mathrm{mM}$ DTT. The single-copy gene PCR reaction mixture contained 1X QuantiTect SYBR® Green (Qiagen, Venlo, The Netherlands) mastermix, 300 nM forward (CAGCAAGTGGGAAGGTGTAATCC) and $500 \mathrm{nM}$ reverse primer (CCCATTCTATCATCAACGGGTACAA) and $5 \mathrm{ng}$ DNA sample.

Each PCR reaction was carried out in triplicate and three non-template controls as well as six inter-run calibrators were included on each 384-well plate. All samples were analyzed using a 7900HT Fast Real-Time PCR system (Life Technologies). Telomere PCR conditions were: 1 cycle at $95^{\circ} \mathrm{C}$ for $10 \mathrm{~min}$ followed by 2 cycles of $15 \mathrm{sec}$ at $94^{\circ} \mathrm{C}$ and $2 \mathrm{~min}$ at $49^{\circ} \mathrm{C}$, and 30 cycles of 15 $\mathrm{sec}$ at $94^{\circ} \mathrm{C}, 20 \mathrm{sec}$ at $62^{\circ} \mathrm{C}$ and $1 \mathrm{~min} 40 \mathrm{sec}$ at $74^{\circ} \mathrm{C}$. Single-copy gene PCR conditions were: 1 cycle at $95^{\circ} \mathrm{C}$ for 10 min followed by 40 cycles of $15 \mathrm{sec}$ at $95^{\circ} \mathrm{C}$ and $1 \min 10 \mathrm{sec}$ at $58^{\circ} \mathrm{C}$.

After thermal cycling, raw data were collected and processed. The relative average telomere length was calculated as the ratio of $\mathrm{C}_{\mathrm{T}}$ (cycle threshold)value of telomere length to single-gene copy number (T/S) in the study subjects compared with that of the averaged T/S value for the study population using the 
qBase software (Biogazelle, Zwijnaarde, Belgium). The program uses modified software from the classic comparative $\mathrm{C}_{\mathrm{T}}$ method taking the single-copy gene into account and uses inter-run calibration algorithms to correct for run-to-run differences. ${ }^{24}$ All samples were analyzed in triplicate and included in the study when the difference in quantification cycle $(\mathrm{Cq})$ value was $<0.50$. The coefficients of variation ( $\mathrm{CV}$ ) within triplicates of the telomere and single-gene assay were $0.48 \%$ and $0.33 \%$, respectively.

\section{Data collection}

Data recorded by the obstetrician at birth included gestational age, birth weight, sex of the twins and parental ages. Gestational age was based on the last menstruation and was calculated as the number of completed weeks of pregnancy. Zygosity was determined at birth by sequential analysis based on sex, choriontype, blood group determined on umbilical cord blood, placental alkaline phosphatase, and, since 1982, DNA fingerprints. ${ }^{25}$ After DNAfingerprinting, a zygosity probability of $0.999 \%$ was reached.

At a later stage, the parents of the twins filled out questionnaires. In this way, parental education were collected retrospectively. Educational level as a proxy of socio economic status (SES) was categorized into three groups according to the Belgian education system; no education or primary school, lower secondary education, and higher secondary education and tertiary education. The twins completed questionnaires to obtain information on smoking status.

Biometric and laboratory measurements were obtained at the research centre during a $2 \mathrm{~h}$ morning session. BMI was calculated as body mass (in $\mathrm{kg}$ ) divided by squared height (in $\mathrm{m}$ ). Total cortisol was determined in $24 \mathrm{~h}$ urine using the ADVIA Centaur Cortisol assay. In fasting blood samples Gama-Glutamyl Transferase was measured on an Olympus AU600 Auto-Analyzer (Kyoto, Japan).

\section{Traffic exposure and land use data}

Residential addresses of the mothers at time of birth of the twin and the residential addresses of the twin at time of the measurement were geocoded. 
Distances to the nearest major road with traffic counts available and traffic density were determined using Geographic Information System (GIS) functions. All GIS analyses were carried out using ArcGIS 10 software. We collected information on two traffic indicators at the mother's residence, i.e., distance to major road and traffic density. Traffic density within a $200 \mathrm{~m}$ radius (buffer) from the residence was equal to the length of each road in this buffer multiplied with the traffic count at each specific road. This was calculated for a $200 \mathrm{~m}$ buffer in steps of $10 \mathrm{~m}$. Traffic counts of 2010 were obtained from the Traffic Centre Flanders, Department of Mobility and Public Works. Streets with low traffic-carrying capacity codes without traffic measurements were assigned a default traffic count of 543 vehicles per 24 hours. Traffic densities within a buffer were multiplied by a weight decreasing with distance, following a Gaussian curve. ${ }^{26}$ Finally the sum was made for the distance-weighted traffic densities (DWTD) in all buffers within $200 \mathrm{~m}$. This was also repeated for 50, 100 and 150 $\mathrm{m}$ buffers.

Semi-natural -, forested -, and agricultural areas (greenness), residential and industrial areas in a $5000 \mathrm{~m}$ radius from the residential address were estimated based on Corine land cover 2000 (European Environment Agency). This was repeated for 4000, 3000, 2000, 1000, 500, 300 and 100 m buffers.

\section{Statistical analysis}

For data management and statistical analyses, we used SAS software, version 9.3 (SAS Institute, Cary, NC). All reported $p$ values are two-sided and were considered statistically significant when $p<0.05$. To examine the association between telomere length in placental tissue at birth and in buccal cells in adulthood, we ranked individual's telomere length from long to short. We did this for telomere length in placental tissue and in buccal cells and calculated based on this the difference or decline in telomere length ranking. A positive value indicates an increase in ranking and a negative value a decrease in ranking.

Mixed modeling was performed to investigate telomere length and telomere ranking in association with covariates. The twins were analyzed as individuals in 
a multilevel regression analysis to account for relatedness between twin members by adding a random intercept to the model. The variance-covariance structure was allowed to differ between the three zygosity-chorionicity groups including dizygotic dichorionic, monozygotic dichorionic, and monozygotic monochorionic.

First mixed modeling without adjustment was performed and subsequently we adjusted for covariates selected a priori, including birth weight, gestational age, sex, zygosity-chorionicity, age, parental education level, smoking, GammaGlutamyl Transferase, total cortisol level, and telomere length in placental tissue.

Finally, we investigated the association between telomere length and telomere ranking in association with traffic and land use indicators with mixed models adjusting for birth weight, gestational age, sex, zygosity-chorionicity, age, parental education level, smoking, Gamma-Glutamyl Transferase, and telomere length in placental tissue.

\section{RESULTS}

\section{Characteristics of the study population}

Table 1 summarizes the characteristics of the study population. Telomere length was measured in placental tissue of 316 twins and in buccal cells of 205 twins. Information on telomere length in buccal cells was available for 205 newborn twins of which 137 (66.8\%) monozygotic and 68 (31.2\%) dizygotic. The study population includes 131 mothers: $72.2 \%(n=148)$ of the participants included both twins from each twin pair, whereas the remaining $27.8 \%(n=57)$ only had one participating twin from each twin pair. At time of the collection of the buccal swabs the twins had a mean (SD) age of 22.7 (3.2) years. The distribution of the residential traffic and land use indicators at adult age and at birth are shown in table 2 . 
Table 1 Study population characteristics

\begin{tabular}{|c|c|c|c|}
\hline Characteristic & $\begin{array}{l}\text { Placental } \\
\text { telomere } \\
\text { length }\end{array}$ & $\begin{array}{l}\text { Buccal } \\
\text { telomere } \\
\text { length } \\
\end{array}$ & $\begin{array}{l}\text { Placental and } \\
\text { buccal telomere } \\
\text { length }\end{array}$ \\
\hline Maternal & $(n=194)$ & $(n=131)$ & $(n=125)$ \\
\hline Maternal age, years & $27.2 \pm 4.3$ & $26.9 \pm 4.1$ & $26.8 \pm 4.1$ \\
\hline \multicolumn{4}{|c|}{ Socioeconomic status: maternal education } \\
\hline Low & $72(38.9)$ & $50(40.7)$ & $46(39.3)$ \\
\hline Middle & $45(24.3)$ & $29(23.6)$ & $28(23.9)$ \\
\hline High & $68(36.8)$ & $44(35.8)$ & $43(36.8)$ \\
\hline Birth & $(n=316)$ & $(n=205)$ & $(n=196)$ \\
\hline Gestational age, weeks & $37.1 \pm 2.4$ & $37.2 \pm 2.4$ & $37.2 \pm 2.5$ \\
\hline Neonate birth weight, $\mathrm{g}$ & $2,562 \pm 473$ & $5,577 \pm 506$ & $2586 \pm 502$ \\
\hline Twin birth year & $1976 \pm 3.2$ & $1976 \pm 3.2$ & $1976 \pm 3.2$ \\
\hline \multicolumn{4}{|l|}{ Zygosity - Chorionicity } \\
\hline Dizygotic-Dichorial & $119(37.7)$ & $68(33.2)$ & $66(33.7)$ \\
\hline Monozygotic-Dichorial & $88(27.9)$ & $63(30.7)$ & $62(31.6)$ \\
\hline Monozygotic-Monochorial & $109(34.5)$ & $74(36.1)$ & $68(34.7)$ \\
\hline Adulthood & $(n=316)$ & $(n=205)$ & $(n=196)$ \\
\hline Age, years & $22.7 \pm 3.0$ & $22.7 \pm 3.2$ & $22.6 \pm 3.1$ \\
\hline \multicolumn{4}{|l|}{ Sex } \\
\hline Male & $144(45.6)$ & $102(49.8)$ & $97(49.5)$ \\
\hline Female & $172(54.4)$ & $103(50.2)$ & $99(50.5)$ \\
\hline Body mass index, $\mathrm{kg} / \mathrm{m}^{2}$ & $21.7 \pm 3.2$ & $21.5 \pm 2.7$ & $21.5 \pm 2.7$ \\
\hline Smokers, $\mathrm{n}$ & $107(33.9)$ & $68(33.2)$ & $66(33.7)$ \\
\hline Gamma-Glutamyl Transferase, U/L & $18.3 \pm 12.0$ & $18.0 \pm 11.4$ & $17.8 \pm 11.3$ \\
\hline Total cortisol $(\mu \mathrm{g} / \mathrm{dl})$ & $91.1 \pm 41.1$ & $92.7 \pm 42.1$ & $92.7 \pm 41.9$ \\
\hline \multicolumn{4}{|l|}{ Complete-pair in final study } \\
\hline One twin & $72(22.8)$ & $57(27.8)$ & $54(27.6)$ \\
\hline Both twins & $244(77.2)$ & $148(72.2)$ & $142(72.4)$ \\
\hline Moved since birth & $207(65.9)$ & $137(66.8)$ & $131(66.8)$ \\
\hline
\end{tabular}




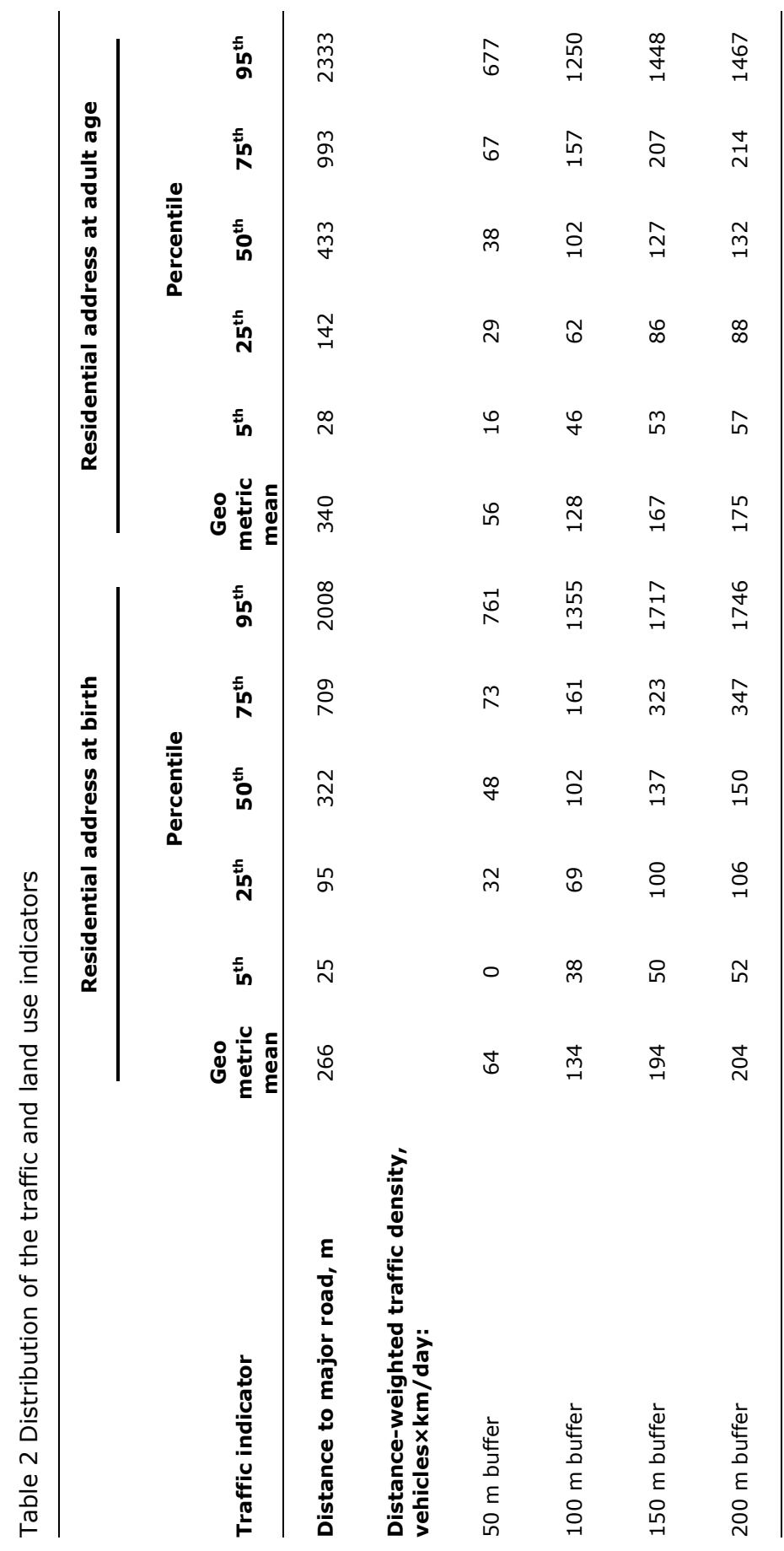




\section{Association telomere length in placental tissue and buccal swabs}

Telomere length in buccal cells in adulthood is positively associated with placental telomere length $(r=0.31, p<0.0001)$ (Fig 1$)$. Telomere repeat copy number-to-single gene copy number (T/S) averaged (SD) 0.89 (0.75) for placenta and $1.04(0.28)$ in adult buccal cells.

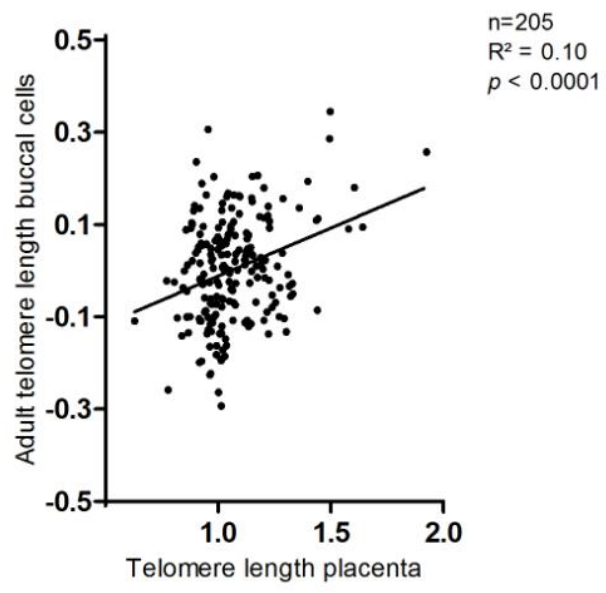

Figure 1 Association between relative telomere length in buccal cells and placenta.

\section{Telomere length in buccal swabs}

We observe longer telomeres in buccal cells in adults with longer telomeres in placental tissue $(+2.04 \%$ per IQR in placental telomere length; $95 \%$ CI 0.5 to 3.6; $p=0.02$ ). Telomere length in buccal cells in adults was significant negatively associated both in single and multiple variable models with parental education (Table 3).

\section{Longitudinal analysis on telomere tracking}

Results in table 4 show that women have an upward shift in ranking compared to men $(+22.5 ; 95 \%$ CI -0.4 to $44.5 ; p=0.05)$ after adjustment for other covariates. Persons with a long telomere length in placental tissue show a stronger downward shift in ranking compared to persons with short placental telomeres $(-38.6 ; 95 \% \mathrm{CI}-48.1$ to $-29.2 ; \mathrm{p}<0.0001)$. 


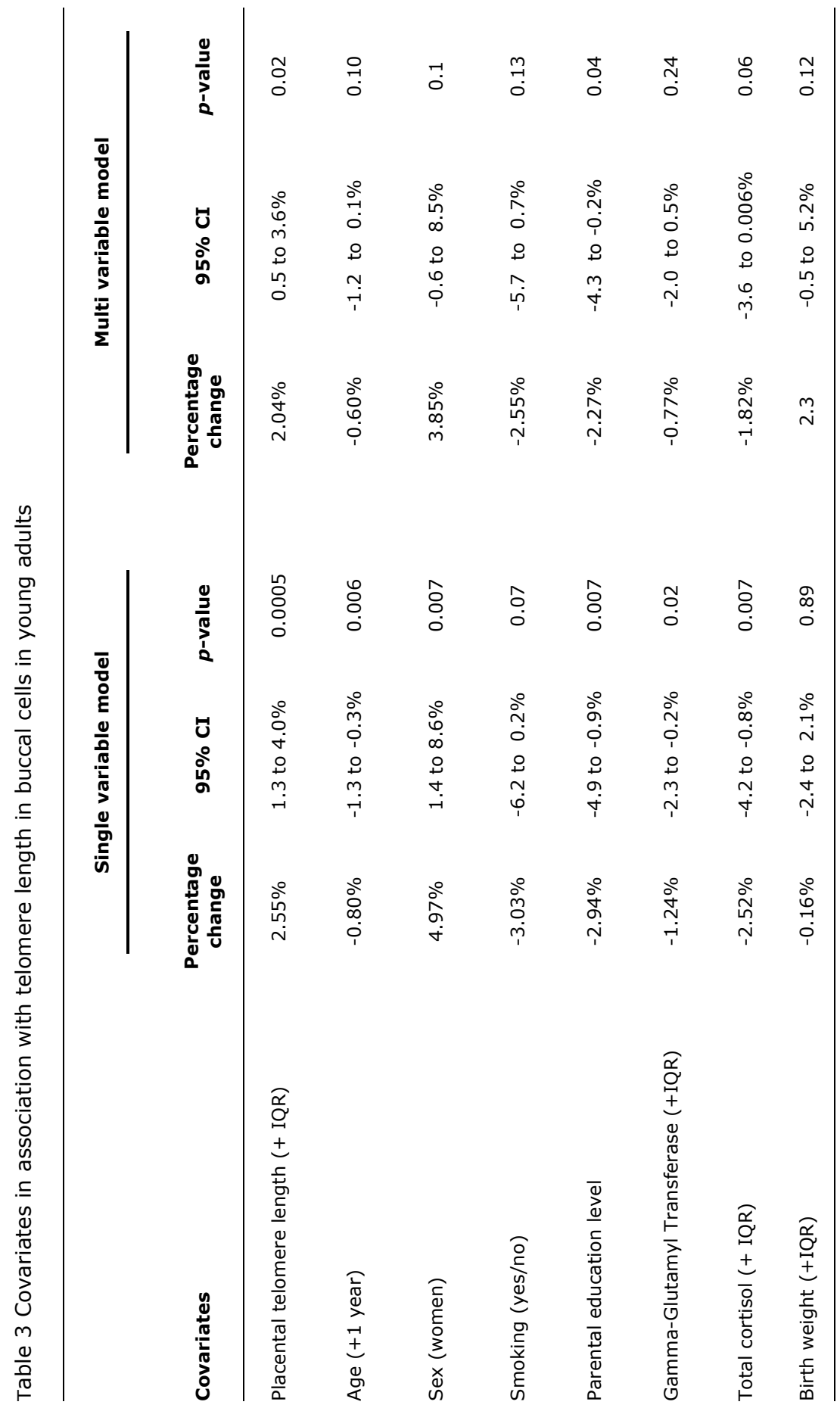




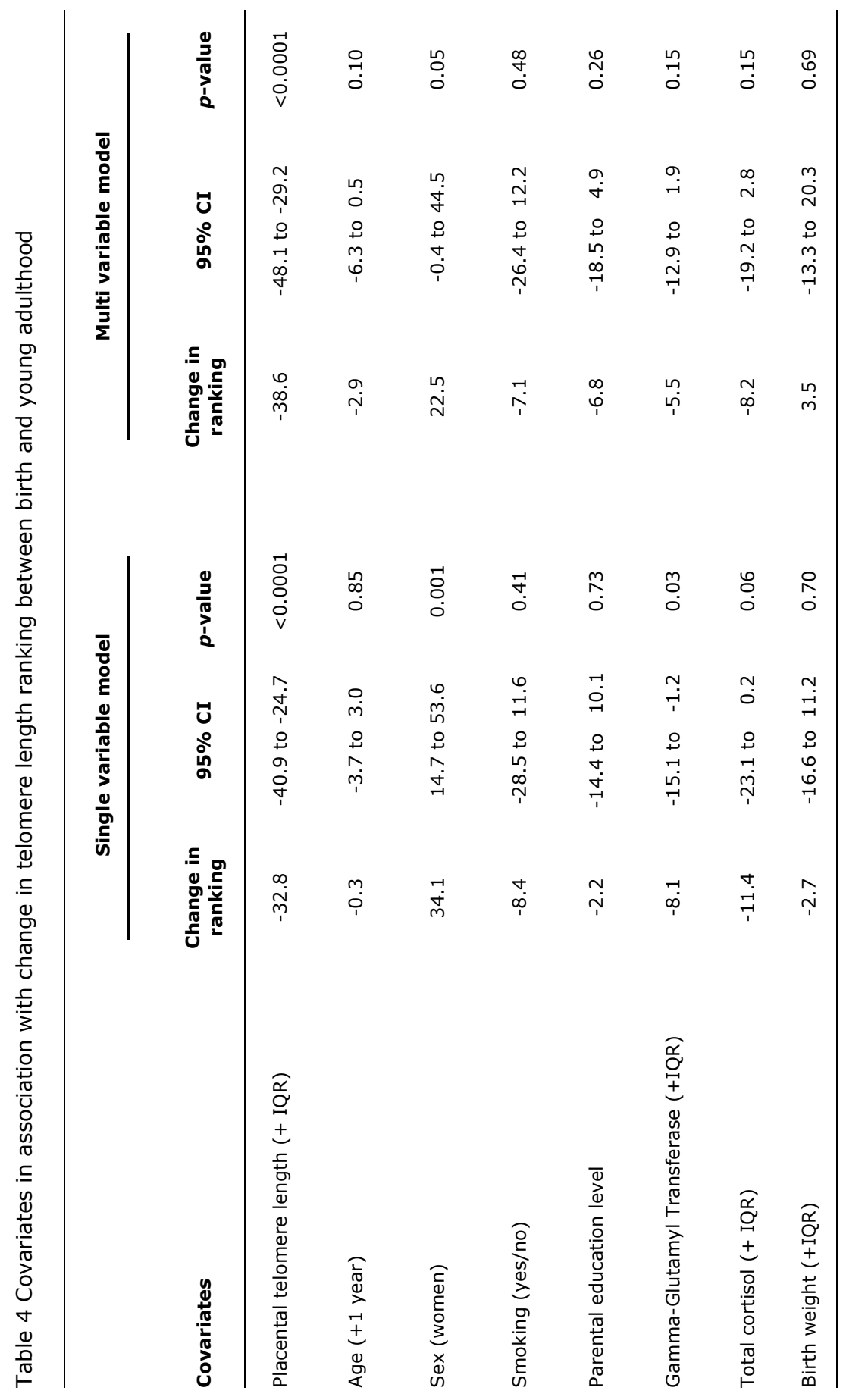




\section{Traffic and land use indicators and buccal telomere length in adults}

Twins living further away from a major road at the birth address (doubling) had besides $3.6 \%$ longer placental telomeres ( $95 \%$ CI 0.2 to $7.2 ; p=0.04$ ) also $2.6 \%$ longer buccal telomere length ( $95 \%$ CI 0.5 to $4.8 ; p=0.02)$. The difference in buccal telomere length was observed among twins who were living at a different address than their birth address at time of the measurement $(n=137)$. Telomere length in buccal cells in young adulthood correlated inversely with distanceweighted traffic density within a $200 \mathrm{~m}$ buffer at the birth address before (Figure 2) and after adjustments (Figure 3). A doubling in distance weighed traffic density within a $200 \mathrm{~m}$ buffer at the birth address was associated with a $-2.90 \%$ decrease in buccal telomere length ( $95 \%$ CI -5.5 to $-0.2 ; p=0.04$ ) among twins who moved during life. We observed no significant effect of traffic indicators at the residential address in young adulthood or in persons living at the same address their whole life (non-movers). Land use indicators were not associated with telomere length at adult age. After additional adjustment for cortisol, the association between buccal telomere length and traffic exposure remained significant (Supplement).
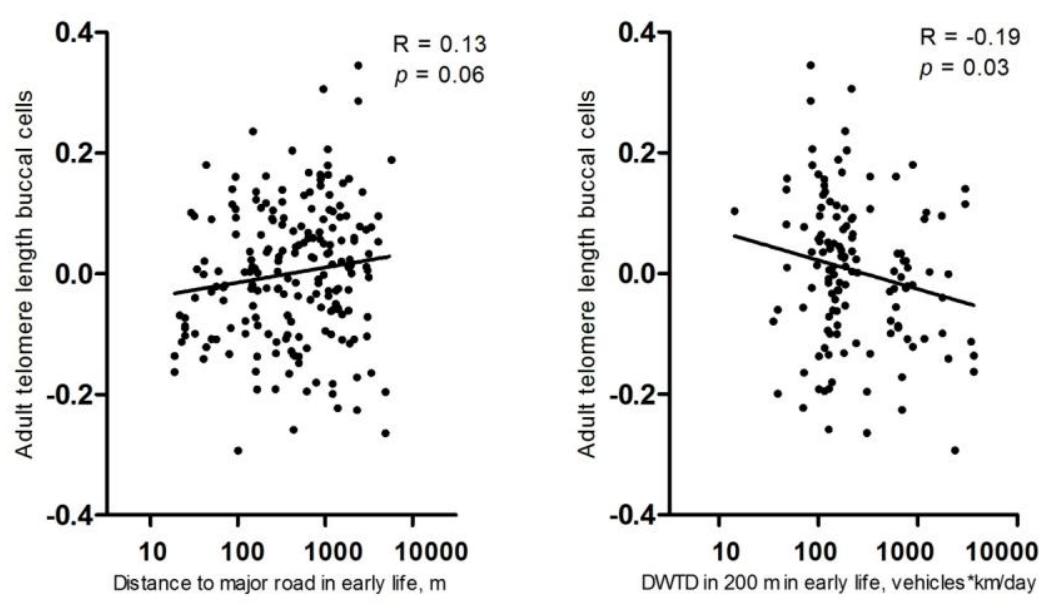

Figure 2 Relative telomere length in buccal cells in association with a) distance to major road; b) distance-weighted traffic density (DWTD) within a $200 \mathrm{~m}$ radius of the residential address at birth. 


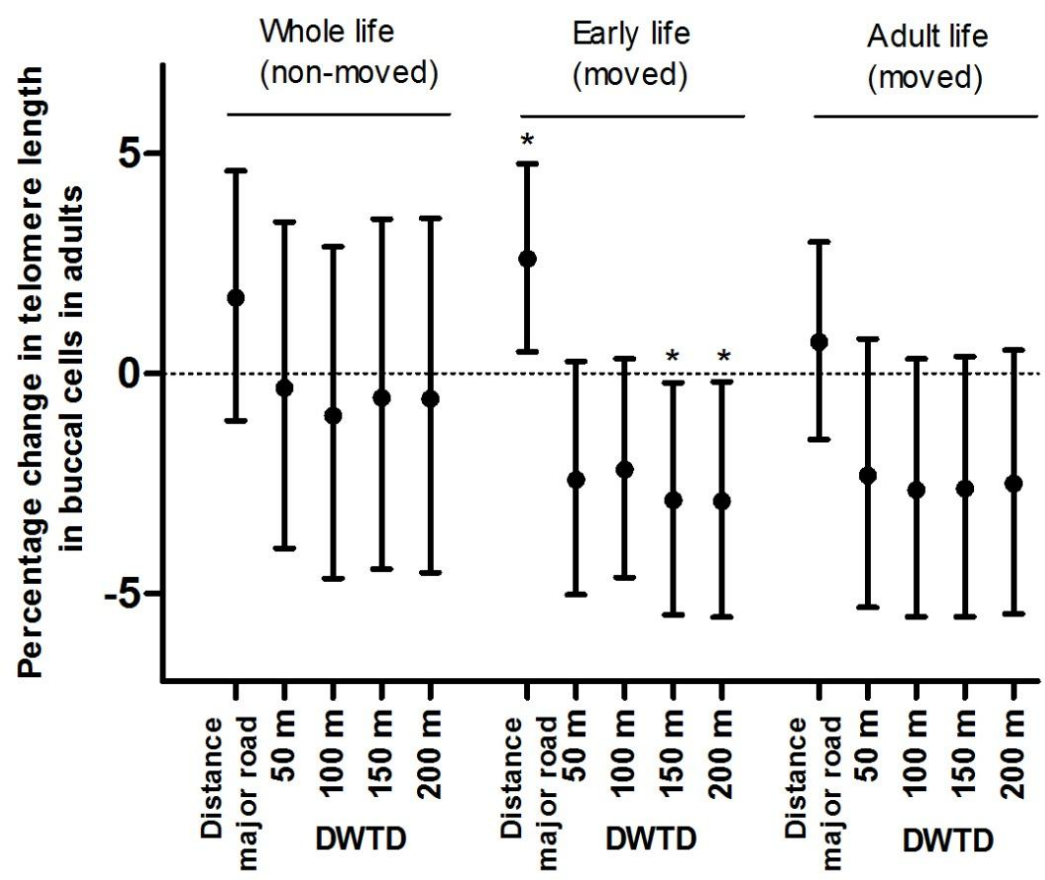

Figure 3 Traffic indicators in association with telomere length in buccal cells. Adjusted for birth weight, gestational age, sex, zygosity-chorionicity, age, parental education level, smoking, Gamma-Glutamyl Transferase, and telomere length in placental tissue. Vertical lines denote $95 \%$ confidence intervals. *indicates significant $(p<0.05)$ change in buccal telomere length in adulthood after a doubling in traffic indicators in early/adult life. DWTD; distance weighted traffic density.

\section{Traffic and land use indicators and buccal telomere ranking}

In twins who moved during life, we observed a negative effect of traffic exposure at the birth address on telomere ranking between birth and young adulthood (Figure 4). A doubling in distance from a major road was significantly associated with an upward shift in ranking $(5.1 ; 95 \%$ CI 0.2 to $9.9 ; p=0.05)$. No effect of land use exposure on telomere length was observed. No associations with traffic or environmental indicators at the residential address in young adulthood or at the residential address in non-movers with adult telomere length were noted. 


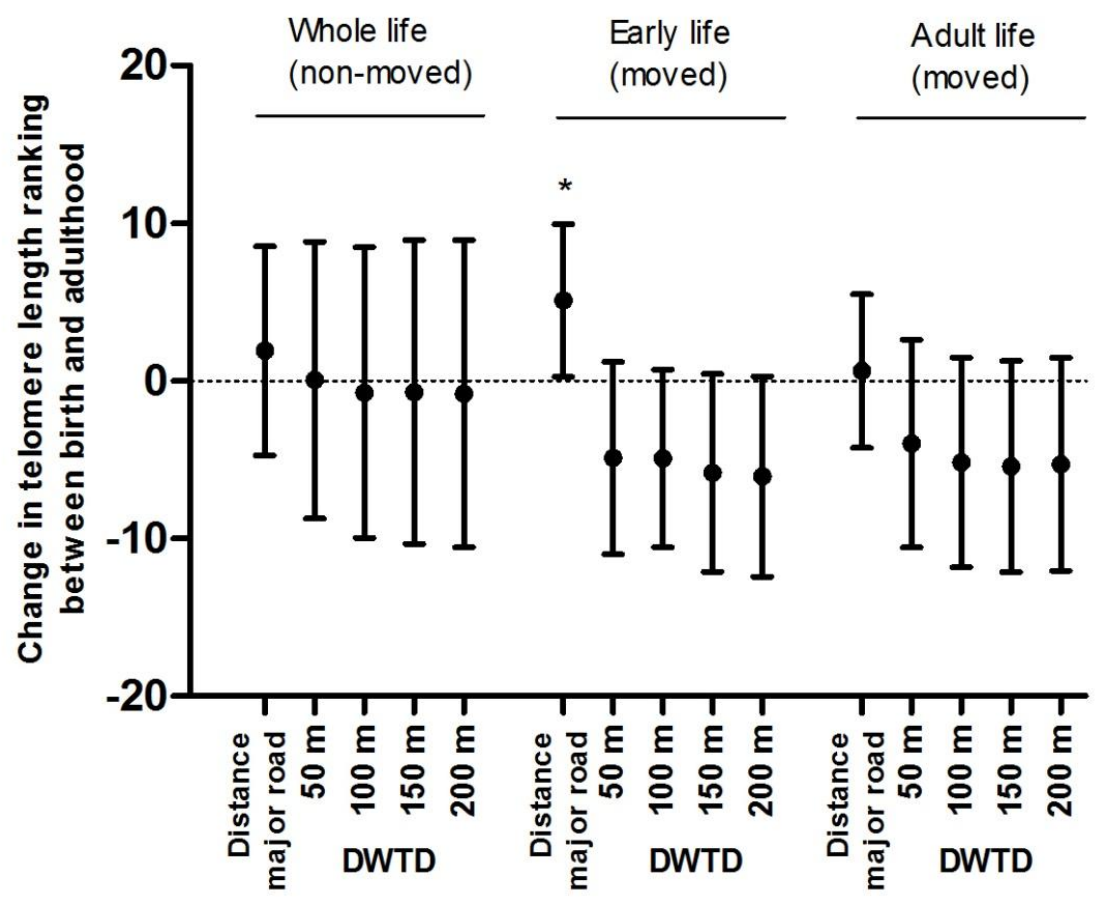

Figure 4 Traffic indicators in association with change in telomere length ranking between birth and adulthood. Adjusted for birth weight, gestational age, sex, zygosity-chorionicity, age, parental education level, smoking, Gamma-Glutamyl Transferase, and telomere length in placental tissue. Vertical lines denote $95 \%$ confidence intervals. *indicates significant $(p<0.05)$ change in telomere length in ranking after a doubling in traffic indicators in early/adult life. DWTD; distance weighted traffic density.

\section{DISCUSSION}

Previously, we reported that maternal residential proximity to traffic and lower residential surrounding greenness is associated with shorter placental telomere length at birth. Here, we studied telomere tracking from birth to young adulthood (18-30 years). We found that telomere attrition was enhanced in men compared with women and newborns with larger telomeres at birth showed a higher attrition rate over the first 3 decades of life. Independent of these two determinants, a lower placental telomere length was observed in adults who had 96 
higher residential exposure to traffic early in life. Our study has important implications as it shows that the effects of traffic related exposure on telomere length are not only perceived at birth but are long lasting over the life course. In addition, we found that higher exposure showed a more rapid decline or attrition over a 30-year period. The combination of both telomere measures at birth and in adulthood is unique and has not been reported before. The importance of early-life determinants of adulthood telomere length have been observed for prenatal stress exposure showing that prenatal exposure to stress is significantly associated with shorter telomere length in young adulthood. ${ }^{27}$

Our findings suggest that attrition rate is more pronounced in newborns with longer telomeres at baseline and are consistent with previous reports of an inverse association between telomere attrition rate and initial telomere length in blood samples. ${ }^{11,28,29}$ Two reasons for such a similar observation in attrition rates in adult studies have been proposed. First, longer telomeres are more susceptible for oxidative stress due the sensitivity of the telomeric $G$ triplet to oxidative damage. ${ }^{11}$ Second, telomerase act preferentially on short telomeres as an protection mechanism. ${ }^{29}$

We noted that telomere length in buccal cells was longer in women than men and that men show a downward shift in ranking compared to women. This is confirmed by evidence in literature. Several studies in adults noted that telomere length was longer in women than in men. ${ }^{30-33}$ In contrast to this, telomere length in newborns does not differ between males and females. ${ }^{34}$ Indicating that the difference in telomere length between men and women is the result of age-dependent telomere attrition. ${ }^{33}$

We assume that the underlying mechanism between traffic exposure and telomere length is oxidative stress and inflammation. Road traffic contributes largely to particulate matter pollution. In the lungs phagocytosis of these particles by alveolar macrophages can result in oxidative stress and inflammation in the lungs. ${ }^{35,36}$ However, ultrafine particles can even translocate into the blood circulation and result in local effects. ${ }^{37}$ Telomere are highly sensitive to oxidative stress due to their high guanine content and the deficient repair system of single-strand breaks. ${ }^{38}$ 
The present study should be interpreted within in the context of its limitations. First, telomere length in adulthood was not measured in blood but in buccal cells. Despite the absolute difference in telomere length between tissues a strong intra-individuals correlations in telomere length exist between blood and buccal cells. ${ }^{39}$ In adults ${ }^{40}$ and even at birth ${ }^{34,41}$ a high synchrony in telomere length between tissues is present and age-dependent telomere attrition during adulthood is very similar across different somatic tissues. Buccal cells may provide a better estimation of telomere length since they are more inert and less influenced by regulatory factors than white blood cells due to the different populations of cells in blood. ${ }^{42}$

To summarize, we showed an correlation between telomere length in placental tissue and in buccal cells in young adulthood. In addition, we noted that traffic related exposure in early-life is not only associated with shorter telomere length in placental tissue but also telomere length in young adulthood. As telomere length is a biomarker of ageing, these results suggest that environmental exposure in early-life may have implications for health outcome later in life and that age-related diseases may have their origin in the early-life environment.

\section{FUNDING}

This investigation is supported by the EU research council "project ENVIRONAGE" (ERC-2012-StG 310890) and Flemish Scientific Fund (G073315N). Since its start, the East Flanders Prospective Twin Survey has been partly supported by grants from the Fund of Scientific Research Flanders and Twins, a non-profit Association for Scientific Research in Multiple Births (Belgium). 


\section{REFERENCES}

1. Blackburn EH. Switching and signaling at the telomere. Cell. 2001;106:661-673.

2. Harley $C B$, Futcher $A B$ and Greider $C W$. Telomeres shorten during ageing of human fibroblasts. Nature. 1990;345:458-60.

3. Collins $\mathrm{K}$ and Mitchell JR. Telomerase in the human organism. Oncogene. 2002;21:564-79.

4. Haycock PC, Heydon E, Kaptoge S, Butterworth AS, Thompson A and Willeit $P$. Leucocyte telomere length and risk of cardiovascular disease: systematic review and meta-analysis. BMJ (Clinical research ed). $2014 ; 349$.

5. Zhao J, Miao K, Wang $\mathrm{H}$, Ding $\mathrm{H}$ and Wang DW. Association between telomere length and type 2 diabetes mellitus: a meta-analysis. PLoS One. 2013;8:e79993.

6. Wentzensen IM, Mirabello L, Pfeiffer RM and Savage SA. The association of telomere length and cancer: a meta-analysis. Cancer epidemiology, biomarkers \& prevention : a publication of the American Association for Cancer Research, cosponsored by the American Society of Preventive Oncology. 2011;20:1238-50.

7. Ma H, Zhou Z, Wei S, Liu Z, Pooley KA, Dunning AM, et al. Shortened telomere length is associated with increased risk of cancer: a metaanalysis. PLoS One. 2011;6:e20466.

8. Kimura M, Hjelmborg JV, Gardner JP, Bathum L, Brimacombe M, Lu X, et al. Telomere length and mortality: a study of leukocytes in elderly Danish twins. American journal of epidemiology. 2008;167:799-806.

9. Bakaysa SL, Mucci LA, Slagboom PE, Boomsma DI, McClearn GE, Johansson $B$, et al. Telomere length predicts survival independent of genetic influences. Aging Cell. 2007;6:769-774.

10. Chen W, Kimura M, Kim S, Cao X, Srinivasan SR, Berenson GS, et al. Longitudinal versus cross-sectional evaluations of leukocyte telomere length dynamics: age-dependent telomere shortening is the rule. $J$ Gerontol A Biol Sci Med Sci. 2011;66:312-9.

11. Aviv A, Chen W, Gardner JP, Kimura M, Brimacombe M, Cao X, et al. Leukocyte telomere dynamics: longitudinal findings among young adults in the Bogalusa Heart Study. American journal of epidemiology. 2009;169:323-9.

12. Farzaneh-Far R, Lin J, Epel E, Lapham K, Blackburn E and Whooley MA. Telomere length trajectory and its determinants in persons with coronary artery disease: longitudinal findings from the heart and soul study. PLoS One. 2010;5:e8612.

13. Gardner JP, Li S, Srinivasan SR, Chen W, Kimura M, Lu X, et al. Rise in insulin resistance is associated with escalated telomere attrition. Circulation. 2005;111:2171-7.

14. Frenck RW, Jr., Blackburn EH and Shannon KM. The rate of telomere sequence loss in human leukocytes varies with age. ProcNatIAcadSciUSA. 1998;95:5607-5610.

15. Rufer N, Brummendorf TH, Kolvraa S, Bischoff C, Christensen K, Wadsworth $\mathrm{L}$, et al. Telomere fluorescence measurements in granulocytes and $\mathrm{T}$ lymphocyte subsets point to a high turnover of 
hematopoietic stem cells and memory $\mathrm{T}$ cells in early childhood. $J$ Exp Med. 1999;190:157-67.

16. Benetos A, Kark JD, Susser E, Kimura M, Sinnreich R, Chen W, et al. Tracking and fixed ranking of leukocyte telomere length across the adult life course. Aging Cell. 2013;12:615-21.

17. Hoxha M, Dioni L, Bonzini M, Pesatori AC, Fustinoni S, Cavallo D, et al. Association between leukocyte telomere shortening and exposure to traffic pollution: a cross-sectional study on traffic officers and indoor office workers. EnvironHealth. 2009;8:41.

18. McCracken J, Baccarelli A, Hoxha M, Dioni L, Melly S, Coull B, et al. Annual ambient black carbon associated with shorter telomeres in elderly men: Veterans Affairs Normative Aging Study. EnvironHealth Perspect. 2010;118:1564-1570.

19. Bijnens E, Zeegers MP, Gielen M, Kicinski M, Hageman GJ, Pachen D, et al. Lower placental telomere length may be attributed to maternal residential traffic exposure; a twin study. Environment international. 2015;79:1-7.

20. Derom C, Thiery E, Peeters $H$, Vlietinck R, Defoort P and Frijns JP. The East Flanders Prospective Twin Survey (EFPTS): an actual perception. Twin research and human genetics: the official journal of the International Society for Twin Studies. 2013;16:58-63.

21. Loos RJ, Beunen G, Fagard R, Derom C and Vlietinck R. The influence of zygosity and chorion type on fat distribution in young adult twins consequences for twin studies. Twin Res. 2001;4:356-364.

22. Gielen M, Hageman G, Pachen D, Derom C, Vlietinck R and Zeegers MP. Placental telomere length decreases with gestational age and is influenced by parity: a study of third trimester live-born twins. Placenta. 2014;35:791-796.

23. Cawthon RM. Telomere length measurement by a novel monochrome multiplex quantitative PCR method. Nucleic Acids Res. 2009;37:e21.

24. Hellemans J, Mortier G, De Paepe A, Speleman F and Vandesompele J. qBase relative quantification framework and software for management and automated analysis of real-time quantitative PCR data. Genome biology. 2007;8:R19.

25. Vlietinck R. Determination of the zygosity of twins Leuven: Katholieke Universiteit Leuven; 1986: 1-123.

26. Pearson $\mathrm{RL}$, Wachtel $\mathrm{H}$ and Ebi $\mathrm{KL}$. Distance-weighted traffic density in proximity to a home is a risk factor for leukemia and other childhood cancers. J Air Waste Manag Assoc. 2000;50:175-180.

27. Entringer S, Epel ES, Kumsta R, Lin J, Hellhammer DH, Blackburn EH, et al. Stress exposure in intrauterine life is associated with shorter telomere length in young adulthood. ProcNatIAcadSciUSA. 2011;108:E513-E518.

28. Weischer M, Bojesen SE and Nordestgaard BG. Telomere shortening unrelated to smoking, body weight, physical activity, and alcohol intake: 4,576 general population individuals with repeat measurements 10 years apart. PLoS Genet. 2014;10:e1004191.

29. Nordfjall K, Svenson U, Norrback KF, Adolfsson R, Lenner P and Roos G. The individual blood cell telomere attrition rate is telomere length dependent. PLoS Genet. 2009;5:e1000375. 
30. Benetos A, Okuda K, Lajemi M, Kimura M, Thomas F, Skurnick J, et al. Telomere length as an indicator of biological aging: the gender effect and relation with pulse pressure and pulse wave velocity. Hypertension. 2001;37:381-385.

31. Elbers CC, Garcia ME, Kimura M, Cummings SR, Nalls MA, Newman AB, et al. Comparison between southern blots and GPCR analysis of leukocyte telomere length in the health $\mathrm{ABC}$ study. J Gerontol A Biol SCi Med Sci. 2014;69:527-31.

32. Nawrot TS, Staessen JA, Gardner JP and Aviv A. Telomere length and possible link to $X$ chromosome. Lancet. 2004;363:507-510.

33. Mayer S, Bruderlein S, Perner S, Waibel I, Holdenried A, Ciloglu N, et al. Sex-specific telomere length profiles and age-dependent erosion dynamics of individual chromosome arms in humans. Cytogenet Genome Res. 2006;112:194-201.

34. Okuda K, Bardeguez A, Gardner JP, Rodriguez P, Ganesh V, Kimura M, et al. Telomere length in the newborn. PediatrRes. 2002;52:377-381.

35. Iwai K, Adachi S, Takahashi M, Moller L, Udagawa T, Mizuno S, et al. Early oxidative DNA damages and late development of lung cancer in diesel exhaust-exposed rats. Environ Res. 2000;84:255-264.

36. Li YJ, Takizawa H, Azuma A, Kohyama T, Yamauchi Y, Takahashi S, et al. Disruption of Nrf2 enhances susceptibility to airway inflammatory responses induced by low-dose diesel exhaust particles in mice. ClinImmunol. 2008;128:366-373.

37. Nemmar A, Hoet PH, Vanquickenborne B, Dinsdale D, Thomeer $M$, Hoylaerts MF, et al. Passage of inhaled particles into the blood circulation in humans. Circulation. 2002;105:411-414.

38. von Zglinicki T. Role of oxidative stress in telomere length regulation and replicative senescence. AnnNYAcadSci. 2000;908:99-110.

39. Gadalla SM, Cawthon R, Giri N, Alter BP and Savage SA. Telomere length in blood, buccal cells, and fibroblasts from patients with inherited bone marrow failure syndromes. Aging (Albany NY). 2010;2:867-74.

40. Daniali L, Benetos A, Susser E, Kark JD, Labat C, Kimura M, et al. Telomeres shorten at equivalent rates in somatic tissues of adults. NatCommun. 2013;4:1597.

41. Youngren $K$, Jeanclos $E$, Aviv $H$, Kimura M, Stock J, Hanna M, et al. Synchrony in telomere length of the human fetus. HumGenet. 1998;102:640-643.

42. Shalev I. Early life stress and telomere length: investigating the connection and possible mechanisms: a critical survey of the evidence base, research methodology and basic biology. Bioessays. 2012;34:94352. 


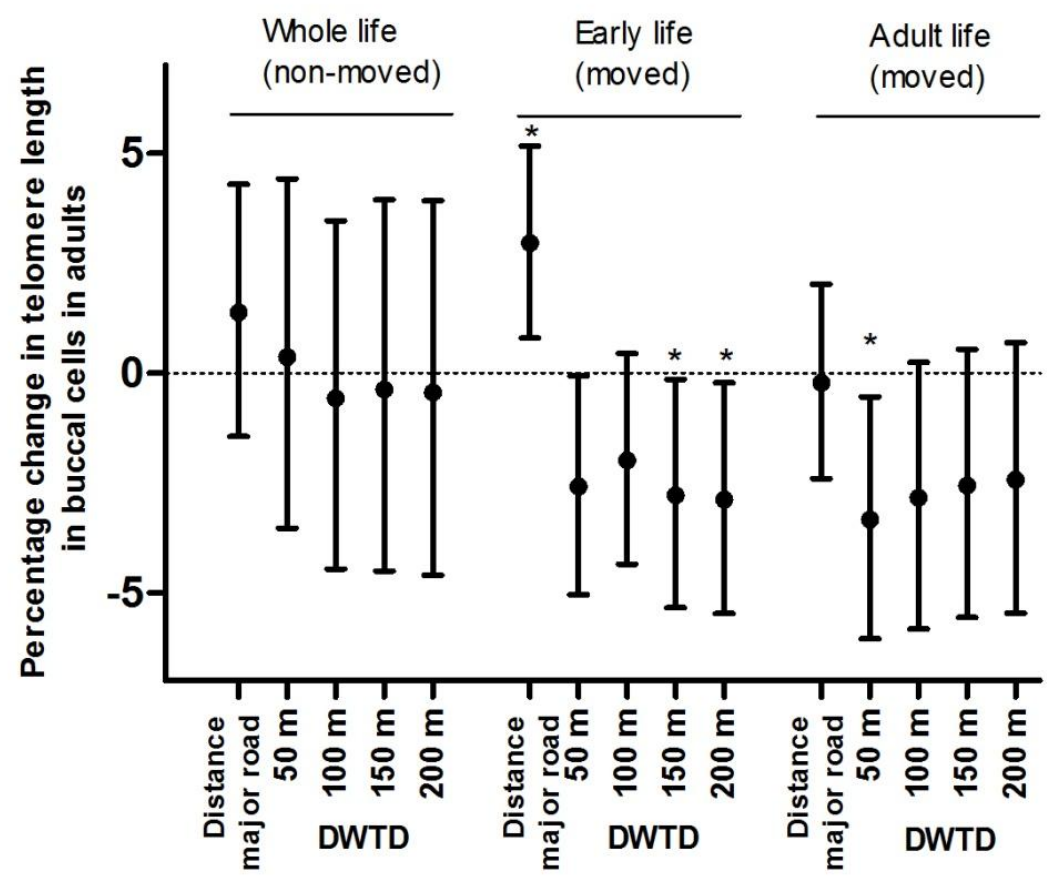

Supplement table 1 Traffic indicators in association with telomere length in buccal cells. Adjusted for birth weight, gestational age, sex, zygosity-chorionicity, age, parental education level, smoking, Gamma-Glutamyl Transferase, total cortisol, and telomere length in placental tissue. In the twins who moved during life, we additionally adjust for traffic indicators in adulthood/early-life. Vertical lines denote 95\% confidence intervals. *indicates significant $(p<0.05)$ change in buccal telomere length in adulthood after a doubling in traffic indicators in early/adult life. DWTD; distance weighted traffic density. 


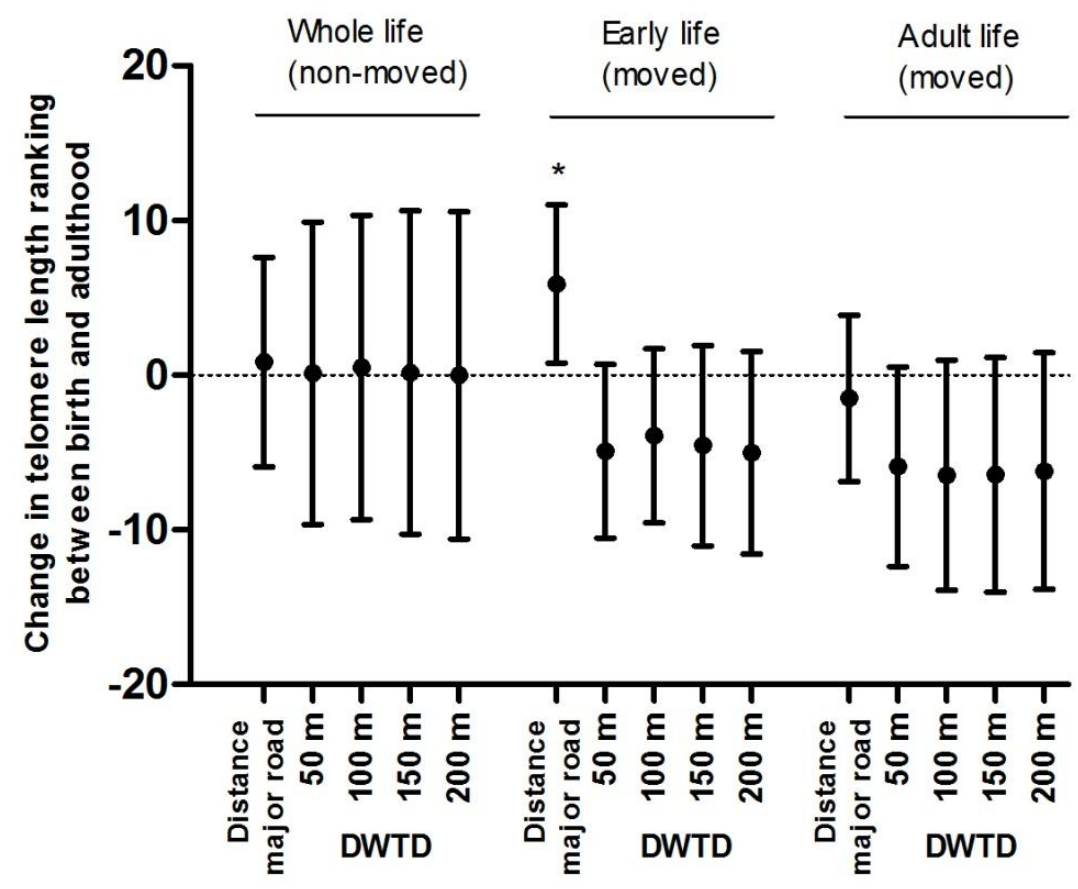

Supplement table 2 Traffic indicators in association with change in telomere length ranking between birth and adulthood. Adjusted for birth weight, gestational age, sex, zygosity-chorionicity, age, parental education level, smoking, Gamma-Glutamyl Transferase, total cortisol, and telomere length in placental tissue. In the twins who moved during life, we additionally adjust for traffic indicators in adulthood/early-life. Vertical lines denote $95 \%$ confidence intervals. *indicates significant $(p<0.05)$ change in telomere length in ranking after a doubling in traffic indicators in early/adult life. DWTD; distance weighted traffic density. 


\section{CHAPTER 6}

\section{Blood pressure in young adulthood and residential exposure of traffic and greenness in the early-life environment of twins}

Esmée M Bijnens ${ }^{1,2}$, Maurice P Zeegers ${ }^{2}$, Ruth JF Loos $^{3}$, Marij Gielen $^{2}$, Robert Vlietinck ${ }^{4}$, Catherine Derom ${ }^{4,5}$,Tim S Nawrot ${ }^{1,6}$

1. Centre for Environmental Sciences, Hasselt University, Diepenbeek, Belgium

2. Department of Complex Genetics, NUTRIM School of Nutrition and Translational Research in Metabolism, Maastricht University Medical Centre, The Netherlands

3. The Genetics of Obesity and Related Metabolic Traits Program, The Charles Bronfman Institute for Personalized Medicine, The Mindich Child Health and Development Institute, The Icahn School of Medicine at Mount Sinai, New York, United States

4. Centre of Human Genetics, University Hospitals Leuven, Leuven, Belgium

5. Department of Obstetrics and Gynaecology, Ghent University Hospital, Ghent, Belgium

6. Department of Public Health, Leuven University (KU Leuven), Leuven, Belgium 


\section{ABSTRACT}

Previous research shows that, besides risk factors in adult life, the early-life environment can influence blood pressure and hypertension in adults. However, the effects of residential traffic exposure and residential greenness in the earlylife on blood pressure are currently unknown.

Ambulatory (24-hour) blood pressures of 278 twins (132 pairs) of the East Flanders Prospective Twin Survey were obtained at the age of 18 to 25 years. Prenatal and adulthood residential addresses were geocoded and used to assign prenatal and postnatal traffic and greenness indicators. Residential surrounding greenness was defined as semi-natural -, forested - and agricultural area based on CORINE Land Cover. Mixed modelling was performed to investigate blood pressure in association with traffic exposure and greenness while adjusting for potential confounding factors.

Among twins who were living at a different address than their birth address at time of the measurement $(n=181)$, night-time blood pressure was inversely associated with residential surrounding greenness at adult age as well as with residential greenness in early-life. After additional adjustment for residential greenness exposure in adulthood, an interquartile increase in residential greenness exposure in early-life (5000 m radius) was associated with a 2.42 $\mathrm{mmHg}(95 \% \mathrm{CI}:-4.7$ to $-0.2 ; \mathrm{p}=0.04)$ decrease in adult night systolic blood pressure. We found no significant effect of adult residential greenness with adult blood pressure, while accounting for the early-life greenness exposure.

Lower residential greenness in the early-life environment was independently associated with a higher adult blood pressure. This indicates that residential greenness during the early-life environment has persistent effects on blood pressure 


\section{INTRODUCTION}

High blood pressure is the leading global risk factor for cardiovascular disease and mortality in the world. ${ }^{1,2}$ Long-term exposure to air pollution has been associated with increased blood pressure ${ }^{3}$ and measures of atherosclerosis, including carotid-intima-media thickness. ${ }^{4}$ In a meta-analysis of 113,926 participants of the ESCAPE study, a weak positive association was found between high traffic exposure in $100 \mathrm{~m}$ of the residence and increased systolic and diastolic blood pressure, and a elevated odds ratio for prevalent hypertension. ${ }^{5}$ Blood pressure tracks over time and childhood blood pressure is closely related with adult blood pressure, increasing later cardiovascular risk. ${ }^{6}$

Given that an unfavorable intrauterine environment may contribute to increased blood pressure, ${ }^{7}$ we hypothesized that exposure to traffic related air pollution and residential greenness during early-life might be associated with higher blood pressure in early adulthood. Prenatal exposure to air pollutants may influence epigenetic changes in placental tissue, which might result in fetal growth disturbance, an subsequentlymake children more susceptible to the development of cardiovascular pathologies and disease later in life. Until now, studies on residential greenness and land cover are limited. In the few studies conducted in healthy populations of children or young adults, childhood or recent exposures to greenness has been associated with blood pressure. ${ }^{8-10} \mathrm{~A}$ study in 2,076 German children showed that lower residential greenness was associated with higher blood pressure in 10 year-old children living in an urbanised area. ${ }^{8} \mathrm{~A}$ Dutch study investigating the effect of neighbourhood-level environmental stressors on blood pressure among different ethnic groups observed that living in a neighbourhood with a high quality of green space was associated with a lower systolic blood pressure and lower odds of hypertension in Moroccans. ${ }^{9}$ Similar but non-significant associations were observed among Dutch and Turkish ethnic groups. ${ }^{9}$ In addition, among 3,416 pregnant women of the city Kaunas, Lithuania an association was observed between proximity of the place of residence to green spaces and lower blood pressure. ${ }^{10}$ To understand the role of early-life traffic related exposure and residential greenness in blood pressure tracking into adulthood, we investigated the association between early-life 
exposure of these environmental exposures on blood pressure in young adulthood.

\section{METHODS}

\section{Subjects}

The East Flanders Prospective Twin Survey (EFPTS), a population based register of multiple births in the province of East-Flanders (Belgium), started in 1964 to enrol twins at birth. ${ }^{11}$ The twin cohort in our analysis was based on a previously designed twin study conducted containing 424 twin pairs. ${ }^{12}$ From this population we could obtain 333 twins born between 1975 and 1982. We excluded twins born before 1975 since no major changes in the road network have occurred in East-Flanders since 1974. Their addresses at birth and at adult age were geocoded. Twins with missing data were excluded; gestational age $(n=4)$, parental education level $(n=17)$, BMI $(n=1), 24$ h urinary sodium and potassium $(n=6)$, Gamma-Glutamyl Transferase $(n=9)$, age mother $(n=9)$, neigbourhood SES $1994(n=3)$, blood pressure $(n=6)$, resulting in a final study population of 278 persons, 170 monozygotic and 108 dizygotic twins.

\section{Collection maternal and neonatal data}

Data recorded by the obstetrician at birth included gestational age, birth weight, sex of the twins and parental ages. Gestational age was based on the mother's last menstruation and was calculated as the number of completed weeks of pregnancy. Zygosity was determined by sequential analysis based on sex, choriontype, blood groups based on umbilical cord blood, placental alkaline phosphatase, and, since 1982, DNA fingerprints. ${ }^{13}$ After DNA-fingerprinting, zygosity was determined with a $0.999 \%$ probability. At a later stage, the parents of the twins filled out questionnaires. In this way, maternal smoking during pregnancy and parental education were collected retrospectively. Educational level as a proxy of socio economic status (SES) was categorized into three groups according to the Belgian education system; no education or primary school, lower secondary education, and higher secondary education and tertiary education. In addition to individual SES data, we gathered information on 
neighborhood SES. Based on their home address, all mothers were assigned to statistical sectors (average area $=1.55 \mathrm{~km}^{2}$ ), the smallest administrative entity for which statistical data are produced by the Belgian National Institute of Statistics (NIS). Belgian census data (FOD Economie/DG Statistiek) derived from the NIS were used to define neighborhood SES based on annual household income in the year 1994.

\section{Collection data adulthood}

Biometric and laboratory measurements were obtained at the research centre during a $2 \mathrm{~h}$ morning session. Standing height and weight were measured as described in detail before. ${ }^{14}$ BMI was calculated as body mass (in $\mathrm{kg}$ ) divided by squared height (in $\mathrm{m}$ ). The twins completed questionnaires to obtain information on smoking status and physical activity. Regarding habitual physical activity, the twins rated themselves on a 10-point scale after brief instructions, where 1 represented very little and 10 very intensive physical activity. For example, a person with deskbound work, who goes to work by foot and works in the garden in his spare time, was instructed to award himself $4-5$ points.

Fasting blood samples were drawn; Gama-Glutamyl Transferase was measured on an Olympus AU600 Auto-Analyzer (Kyoto, Japan). Potassium and sodium were determined in $24 \mathrm{~h}$ urine with ion-selective electrodes (Olympus AU600 Auto-Analyzer). Before urine collection, participants were asked to select a day of normal routine, to drink normally and refrain from caffeine use, and to refrain from heavy exercise.

\section{Ambulatory blood pressure}

Ambulatory blood pressure was monitored using the SpaceLabs 90207 device (Spacelabs, Inc), as previously described. ${ }^{15}$ The monitor was applied at home on the nondominant arm. They were instructed to perform normal activity, but not to engage in vigorous physical exercise or contact sports. Recording began between 6.00 and $9.00 \mathrm{AM}$ and was finished 24 hours later. The recorders were taken every 15 minutes during daytime (8.00 AM to $10.00 \mathrm{PM}$ ) and every 30 minutes during night-time (10.00 PM to $8.00 \mathrm{AM}$ ). Whenever a reading could not 
be successfully completed, the measurement was repeated 2 minutes later. Readings were automatically rejected when systolic blood pressure was $>220$ $\mathrm{mmHg}$ or $<70 \mathrm{mmHg}$ and diastolic BP was $>140 \mathrm{mmHg}$ or $<40 \mathrm{mmHg}$. In addition to the automatic exclusion of readings by the monitor, individuals were excluded from further analysis when there were no valid measurements in any 2-hour period. Night and day were defined with short fixed-clock time periods that ranged from midnight to 6.00 and from $10.00 \mathrm{AM}$ to $8.00 \mathrm{PM}$. We investigated systolic and diastolic blood pressure during both night and day. Measurements during the morning and evening where excluded.

\section{Traffic exposure and land use data}

Residential addresses of the mothers at time of birth of the twin and the residential addresses of the twin at time of the measurement were geocoded. Distances to the nearest major road with traffic counts available and traffic density were determined using Geographic Information System (GIS) functions. All GIS analyses were carried out using ArcGIS 10 software. We collected information on two traffic indicators: distance to major road, and traffic density. We calculated the distance-weighted traffic density (DWTD) by adding up the traffic density in a $200 \mathrm{~m}$ radius (buffer) from the residence weighted by the distance based on a Gaussian curve. ${ }^{16}$ This was also repeated for 50, 100 and $150 \mathrm{~m}$ buffers. The traffic density in a specific buffer size was equal to the length of each road in this buffer multiplied with the traffic count at each specific road. Traffic counts of 2010 were obtained from the Traffic Centre Flanders, Department of Mobility and Public Works. Streets with low traffic-carrying capacity codes without traffic measurements were assigned a default traffic count of 543 vehicles per day.

Semi-natural -, forested -, and agricultural areas (greenness), residential and industrial areas in a $5000 \mathrm{~m}$ radius from the residential address were estimated based on CORINE Land Cover 2000 (European Environment Agency). This was repeated for 4000, 3000, 2000, 1000, 500, 300 and 100 m buffers. 


\section{Statistical analysis}

For data management and statistical analyses, we used SAS software, version 9.3 (SAS Institute, Cary, NC). All reported p-values are two-sided and were considered statistically significant when $p<0.05$.

Mixed modeling was performed to investigate blood pressure in association with traffic exposure and land-use indicators. The twins were analyzed as individuals in a multilevel regression analysis to account for relatedness between twin members by adding a random intercept to the model. The variance-covariance structure was allowed to differ between the three zygosity-chorionicity groups including dizygotic dichorionic, monozygotic dichorionic, and monozygotic monochorionic. Covariates were selected a priori including sex, gestational age, birth weight, birth year, zygosity-chorionicity group, maternal age, age, smoking, physical activity, BMI, 24h sodium and potassium, gamma-glutamyl transferase, indicators of socioeconomic status (maternal education and neighborhood household income), and smoking during pregnancy. To distinguish between exposure early and late in life, we dived the twins in two groups; twins who where living at the same address their whole life (non-movers) and twins who were living at a different address than their birth address at time of the measurement (movers). In the twins who moved during life, we additionally adjusted for land use/traffic exposure in adulthood/early-life.

In addition, we tested potential effect-modifications of the association between traffic exposure/land-use indicators and blood pressure by zygosity-chorionicity group.

\section{RESULTS}

\section{Characteristics of the study population}

The average age of mothers was 27.4 years at the time twins were born and $14.4 \%$ of the mothers smoked during pregnancy (Table1). At time the blood pressure measurements were taken, the twins had a mean (SD) age of 21 (1.9) years and $31 \%$ of the twins were current smokers. In our final analysis, $95 \%$ 
$(n=264)$ of the participants included both twins from each twin pair, whereas the remaining $5 \%(n=14)$ only had one participating twin from each twin pair. A total of 181 (65.1\%) of the twins moved between birth address and young adulthood (Table 2$)$. No significant interaction by zygosity-chorionicity $(p \geq 0.81)$ was observed in the model of traffic exposure/land-use indicators and blood pressure.

Table 1 Study population characteristics

\begin{tabular}{|c|c|}
\hline Characteristic & \\
\hline Maternal & $(n=146)$ \\
\hline Maternal age, years & $27.4 \pm 4.5$ \\
\hline \multicolumn{2}{|c|}{ Socioeconomic status: maternal education } \\
\hline Low & $59(40.4)$ \\
\hline Middle & $32(21.9)$ \\
\hline High & $55(37.7)$ \\
\hline Neighbourhood income, euro & $19,447 \pm 4,202$ \\
\hline Smoking during pregnancy & $21(14.4)$ \\
\hline Birth & $(n=278)$ \\
\hline Gestational age, weeks & $37.0 \pm 2.4$ \\
\hline Neonate birth weight, $\mathrm{g}$ & $2,524 \pm 497$ \\
\hline \multicolumn{2}{|l|}{ Sex } \\
\hline Male & $149(53.6)$ \\
\hline Female & $129(46.4)$ \\
\hline Twin birth year & $1978 \pm 2.0$ \\
\hline Adulthood & $(n=278)$ \\
\hline Age, years & $20.9 \pm 1.9$ \\
\hline Body mass index, $\mathrm{kg} / \mathrm{m}^{2}$ & $21.1 \pm 2.8$ \\
\hline Smokers, n & $87(31.3)$ \\
\hline Physical activity score & $4.73 \pm 2.2$ \\
\hline Potassium excretion, $\mathrm{mmol} / \mathrm{day}$ & $63.2 \pm 28.4$ \\
\hline Sodium excretion, $\mathrm{mmol} / \mathrm{day}$ & $128.1 \pm 59.4$ \\
\hline Gamma-Glutamyl Transferase, U/L & $16.6 \pm 8.54$ \\
\hline \multicolumn{2}{|l|}{ Zygosity - Chorionicity } \\
\hline Dizygotic-Dichorial & $108(38.8)$ \\
\hline Monozygotic-Dichorial & $83(29.9)$ \\
\hline Monozygotic-Monochorial & $87(31.3)$ \\
\hline \multicolumn{2}{|l|}{ Complete-pair in final study } \\
\hline One twin & $14(5.0)$ \\
\hline Both twins & $264(95.0)$ \\
\hline Moved since birth & $181(65.1)$ \\
\hline
\end{tabular}




\section{Blood pressure in association with exposure during whole life}

In 97 twins living at the same address their entire life (non-movers), significant associations were observed between systolic blood pressure during the night and all land use indicators in a $1000 \mathrm{~m}$ buffer after adjustment for previously mentioned covariates (Figure 1 and supplement figure 1 and 2). An interquartile increase in residential greenness exposure within $1000 \mathrm{~m}$ residential radius was associated with a decrease of $3.06 \mathrm{~mm} \mathrm{Hg}(95 \% \mathrm{CI}:-5.7$ to $-0.39 ; \mathrm{p}=0.03)$ in night-time systolic blood pressure. Diastolic blood pressure during night and day was also inversely associated with greenness in a $300 \mathrm{~m}$ radius $(-4.2 ; 95 \% \mathrm{CI}$ : 6.8 to $-1.6 ; p=0.004,-3.9 ; 95 \% \mathrm{CI}:-6.7$ to $-1.1 ; \mathrm{p}=0.01)$. Night-time systolic and diastolic blood pressure were significantly associated with distance-weighted traffic density in a 50 m buffer $(2.4 ; 95 \% \mathrm{CI}: 1.0$ to $3.8 ; \mathrm{p}=0.002,2.6 ; 95 \% \mathrm{CI}$ : 1.4 to $3.8 ; p=0.0002$ ) (Figure 2 ). No associations were observed in larger buffers.

\section{Blood pressure in association with exposure in early-life}

In the twins who had moved since birth, an increased systolic blood pressure during night was significantly associated with lower greenness and higher residential area in early-life after adjustment for previously mentioned covariates (Supplement table 1). Exposure to land use indicators in early-life remained significant associated with systolic blood pressure during the night, even after additional adjustment for land use indicators in adulthood (figure 1 and supplement figure 1 ). The association with residential greenness was significant for all buffer sizes (residential greenness radius between $100 \mathrm{~m}$ and $5000 \mathrm{~m})$. An interquartile increase in residential greenness exposure in early-life (5000 $\mathrm{m}$ radius) was associated with a $-2.42 \mathrm{mmHg}$ (95 CI: -4.7 to $-0.2 \%$; $\mathrm{p}=0.04$ ) decrease in adult night systolic blood pressure, after additional adjustment for residential greenness exposure in adulthood. Diastolic blood pressure during the night was significantly associated with residential greenness in a $300 \mathrm{~m}$ buffer $(-2.4 ; 95 \% \mathrm{CI}:-4.2$ to $-0.7 ; \mathrm{p}=0.0096)$. No associations were observed between blood pressure and traffic exposure in early-life (Figure 2). Residential greenness indicators were robust for mutually adjustment for distance to major roads, which is a proxy for traffic related exposures. 


\section{Blood pressure in association with exposure in adulthood}

In the movers, night-time blood pressure was inversely associated with residential surrounding greenness at adult age when no adjustments for earlylife exposure were made (Supplement table 2). We found no significant effect of adult land use indicators with adult blood pressure, while accounting for the early-life land use indicators (Figure 1). Only a significant and positive association between diastolic blood pressure during the night and industrial area in a $5000 \mathrm{~m}$ buffer remains $(-2.4 ; 95 \% \mathrm{CI}:-4.6$ to $-0.3 ; \mathrm{p}=0.03)$ (Supplement figure 2). Adult diastolic blood pressure during the day was significantly associated with distance-weighted traffic density. A doubling in distanceweighted traffic density in a $100 \mathrm{~m}$ buffer is associated with a $1.20 \mathrm{~mm} \mathrm{Hg}$ (95\% CI: 0.29 to $2.10 ; \mathrm{p}=0.01$ ) increase in adult diastolic blood pressure after adjusting for previously mentioned covariates and traffic exposure in early-life (Figure 2). 


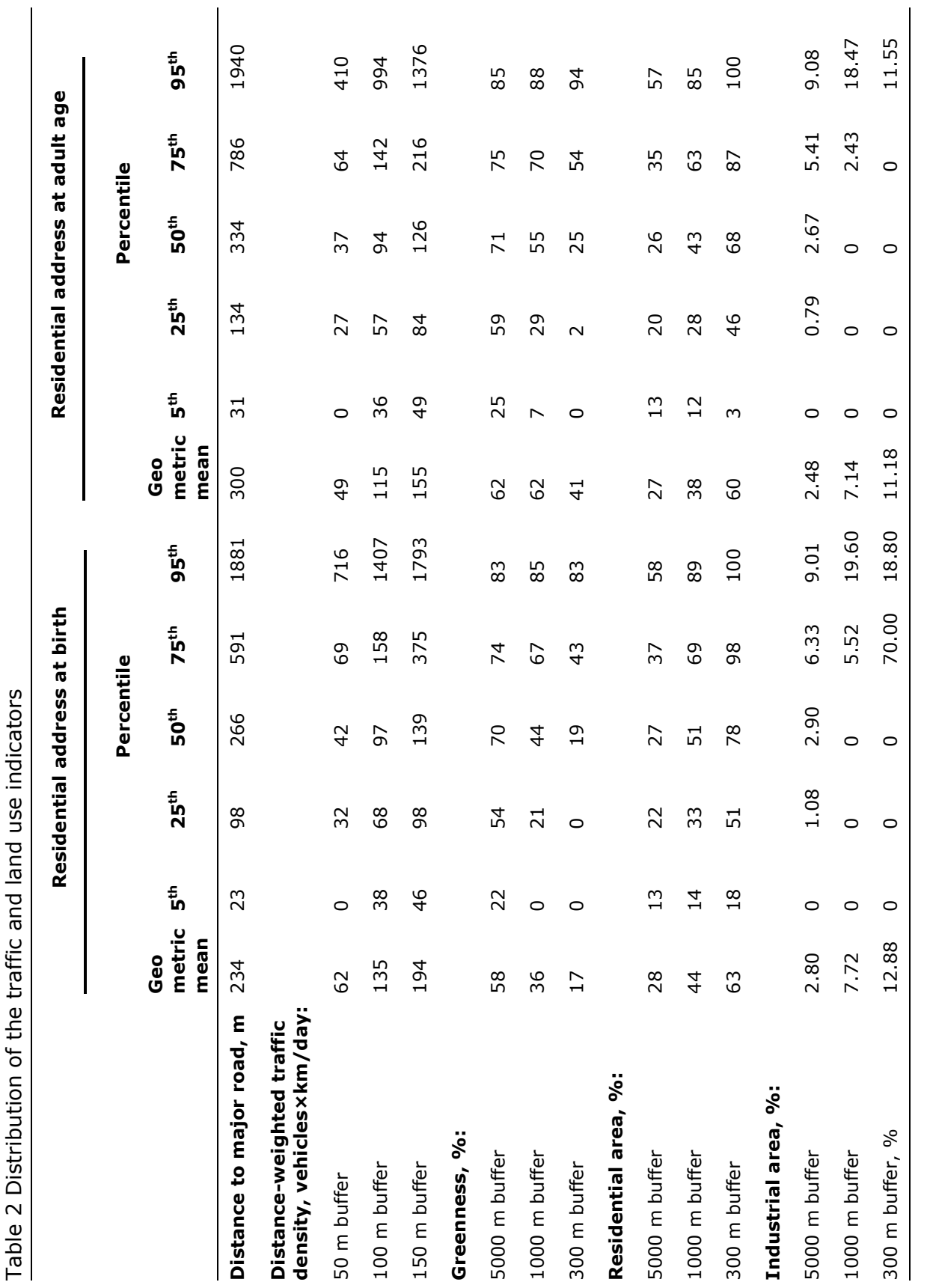



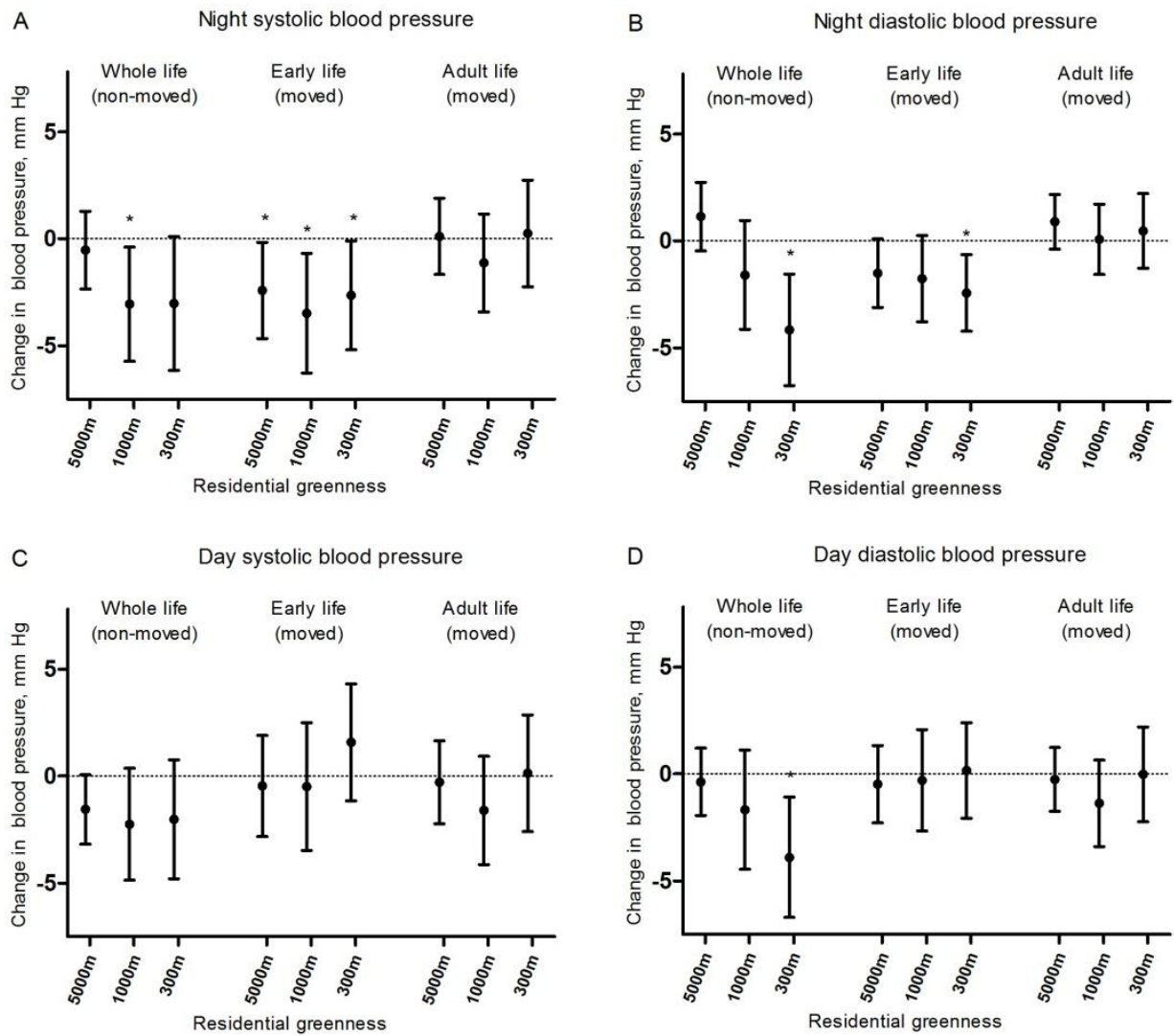

Figure 1: Residential greenness exposure in association with ambulatory blood pressure ( $\mathbf{m m ~ H g ) . ~ A ) ~ N i g h t ~ s y s t o l i c , ~ B ) ~ N i g h t ~ d i a s t o l i c , ~ C ) ~ D a y ~ s y s t o l i c ~ a n d ~ D ) ~ D a y ~}$ diastolic blood pressure. Adjusted for sex, gestational age, birth weight, birth year, zygosity-chorionicity group, maternal age, age, smoking, physical activity, BMI, 24h sodium and potassium, gamma-glutamyl transferase, indicators of socioeconomic status (maternal education and neighborhood household income), and smoking during pregnancy. In the twins who moved during life, we additionally adjust for greenness exposure in adulthood/early-life.Vertical lines denote $95 \%$ confidence intervals. *indicates significant $(p<0.05)$ change in blood pressure after an IQR increase in land use indicators. 

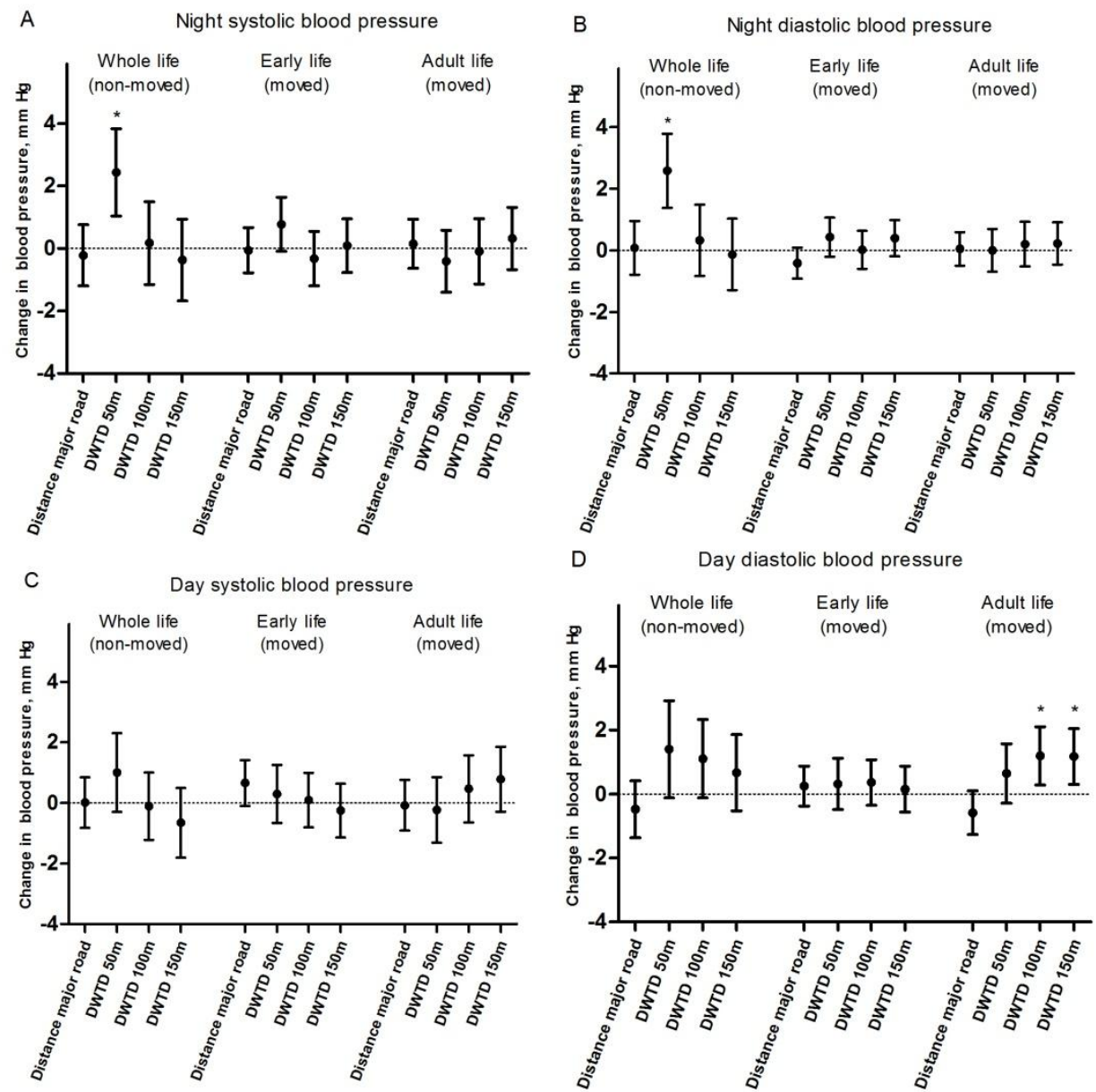

Figure 2: Traffic exposure in association with ambulatory blood pressure ( $\mathrm{mm}$

Hg). A) Night systolic, B) Night diastolic, C) Day systolic and D) Day diastolic blood pressure. Adjusted for sex, gestational age, birth weight, birth year, zygosity-chorionicity group, maternal age, age, smoking, physical activity, BMI, 24h sodium and potassium, gamma-glutamyl transferase, indicators of socioeconomic status (maternal education and neighborhood household income), and smoking during pregnancy. In the twins who moved during life, we additionally adjust for traffic exposure in adulthood/early-life. Vertical lines denote $95 \%$ confidence intervals. *indicates significant $(p<0.05)$ change in blood pressure after a doubling in traffic exposure. DWTD stands for distance-weighted traffic density. 


\section{DISCUSSION}

The key finding of our paper is that in this twin population, increased early-life exposure to residential greenness was associated with lower blood pressure in young adulthood. These results lend further evidence in support of the developmental origins of disease hypothesis for blood pressure ${ }^{17}$ and the role of the residential landscape on the blood pressure life trajectory. Changes in blood pressure in association with land-use exposure were noted during the night and not during the day. There is no clear explanation, but several factors could be involved. Due to physical and mental activity, blood pressure is more variable during the day than during the night whereas blood pressure during the night is more related to basal blood pressure and is a better predictor of mortality and coronary heart disease than day-time blood pressure. ${ }^{18}$

Our findings are in line with previous studies, showing an association between high residential greenness and low blood pressure in children and adults. ${ }^{8,9} \mathrm{~A}$ German study showed that lower residential greenness was positively associated with higher blood pressure in 10-year old children. ${ }^{8}$ In addition to this, a Dutch study observed that a neighbourhood with a high quality of green space was associated with a lower systolic blood pressure and lower odds of hypertension in adults. ${ }^{9}$ Similar results were observed in pregnant women, showing a lower blood pressure with increasing residential proximity to green spaces. ${ }^{10}$ However, no studies are available on greenness exposure during pregnancy in association with blood pressure in the newborn. Although, it is reasonable to expect that maternal exposure to greenness also affects newborn blood pressure since a US cohort study of 1059 mothers and their newborn infants shows that maternal systolic blood pressure during the third trimester of pregnancy is associated with the systolic blood pressure among newborns. ${ }^{19}$

We postulate that the underlying mechanism between surrounding greenness in early-life and blood pressure in young adulthood could be stress. Higher levels of green space in residential neighbourhoods, are linked with lower perceived stress and a healthier cortisol levels in women in a deprived urban population. ${ }^{20}$ Moreover, the presence of multiple psychosocial stressors in women during pregnancy are associated with $1.5 \mathrm{mmHg}$ higher systolic and diastolic BP in the 118 
offspring at the age of 5-7 years. ${ }^{21}$ In addition, the prenatal maternal psychological status also does influence blood pressure response to stress in the child when aged 7-9 years. ${ }^{22}$ Meta-analysis including 50 cohorts and consisting of 617 data points for systolic blood pressure and 547 data points for diastolic blood pressure shows that blood pressure in childhood persists in later life. ${ }^{6}$ The blood pressure tracking was greater for systolic than for diastolic blood pressure. $^{6}$

We did not take into account other types of exposure associated with blood pressure such as air pollution and noise pollution, which to some extend might also explain our findings to greenness. It might be possible that low air pollution concentrations in areas with more surrounding greenness result in a lower blood pressure. Studies in adults show that a long-term exposure to air pollution is associated with higher blood pressure ${ }^{3,23-27}$. The underlying pathway between particulate air pollution and blood pressure may be oxidative stress and inflammation which can affect placental function and fetal growth ${ }^{28}$. Besides air pollution, noise may play an import role in the association between residential greenness and blood pressure since noise exposure can result in a higher blood pressure 29,30. However, the greenness indicators were robust for mutually adjustment for distance to major roads, which is a proxy for traffic related exposures including carbon and noise.

A major advantage of this study is that we individually estimated greenness exposure of each participant. Our study is the first to include information on greenness exposure in the early-life when investigating adult blood pressure. Since we cannot differentiate between prenatal and postnatal exposure to residential greenness, our study is limited to define the exact time period of the exposure. Nevertheless, residential greenness in early-life remained significant even after additional adjustment for residential greenness exposure in adulthood. We found no significant effect of adult residential greenness with adult blood pressure, while accounting for the early-life greenness exposure.

Strengths include the use of ambulatory blood pressure and the possibility to control for potential confounding factors and covariates of blood pressure such as age, gender, smoking status, physical activity, BMI, sodium and potassium 
intake and alcohol consumption. Ambulatory blood pressure was measured at home during usual daily activities and is, compared to office measurements, a better predictor of all cause and cardiovascular mortality and has a moderate-torelatively high tracking stability and predictability over time. ${ }^{31,32}$ There are a number of limitations to our study. The twins were born from 1975 till 1982 and the traffic counts are dated from 2010. A previous study comparing traffic densities with a 11 year difference, observed an increase in traffic over time but showed that the densities at the two time points stayed highly correlated. ${ }^{16}$ We used land-use data from 2000 as no earlier satellite data were available. However, strong correlations have been shown over time between 2000 and 2006 and same results are obtained if the 2006 CORINE Land Cover data were used. Since high blood pressure is the leading global risk factor for cardiovascular disease and mortality in the world, ${ }^{1}$ these findings have public health implications. Previous studies have shown that a small reduction in blood pressure at the population level could have a major impact in reducing morbidity and mortality. ${ }^{33}$ Even, a $2 \mathrm{~mm} \mathrm{Hg}$ lower systolic blood pressure at the population level would result in an $10 \%$ overall reduction in mortality due to stroke mortality and about 7\% lower mortality from ischemic heart disease or other vascular causes in middle age. ${ }^{33}$ Our findings indicate that more surrounding greenness at the residential address in early-life shows lower blood pressure in adult life. This may be especially relevant for policy makers and urban planners for designing healthier urban environments.

\section{FUNDING}

This investigation is supported by the EU research council "project ENVIRONAGE" (ERC-2012-StG 310890) and Flemish Scientific Fund (G073315N). Since its start, the East Flanders Prospective Twin Survey has been partly supported by grants from the Fund of Scientific Research Flanders and Twins, a non-profit Association for Scientific Research in Multiple Births (Belgium). 


\section{REFERENCES}

1. Colin Mathers GS, Maya Mascarenhas. Global Health Risks: Mortality and burden of disease attributable to selected major risks. 2009:70.

2. WHO. Global atlas on cardiovascular disease prevention and control Policies, strategies and interventions. 2011:1+4.

3. Fuks K, Moebus S, Hertel S, Viehmann A, Nonnemacher M, Dragano N, et al. Long-term urban particulate air pollution, traffic noise, and arterial blood pressure. Environ Health Perspect. 2011;119:1706-11.

4. Provost EB, Madhloum N, Int Panis L, De Boever $\mathrm{P}$ and Nawrot TS. Carotid intima-media thickness, a marker of subclinical atherosclerosis, and particulate air pollution exposure: the meta-analytical evidence. PLoS One. 2015;10:e0127014.

5. Fuks KB, Weinmayr G, Foraster M, Dratva J, Hampel R, Houthuijs D, et al. Arterial blood pressure and long-term exposure to traffic-related air pollution: an analysis in the European Study of Cohorts for Air Pollution Effects (ESCAPE). Environ Health Perspect. 2014;122:896-905.

6. Chen $X$ and Wang $Y$. Tracking of blood pressure from childhood to adulthood: a systematic review and meta-regression analysis. Circulation. 2008;117:3171-80.

7. Hogberg L, Cnattingius S, Lundholm C, D'Onofrio BM, Langstrom N and Iliadou AN. Effects of maternal smoking during pregnancy on offspring blood pressure in late adolescence. J Hypertens. 2012;30:693-9.

8. Markevych I, Thiering E, Fuertes E, Sugiri D, Berdel D, Koletzko S, et al. A cross-sectional analysis of the effects of residential greenness on blood pressure in 10-year old children: results from the GINIplus and LISAplus studies. BMC Public Health. 2014;14:477.

9. Agyemang C, van Hooijdonk C, Wendel-Vos W, Ujcic-Voortman JK, Lindeman $E$, Stronks $K$, et al. Ethnic differences in the effect of environmental stressors on blood pressure and hypertension in the Netherlands. BMC Public Health. 2007; 7:118.

10. Grazuleviciene R, Dedele A, Danileviciute A, Vencloviene J, Grazulevicius $\mathrm{T}$, Andrusaityte $\mathrm{S}$, et al. The influence of proximity to city parks on blood pressure in early pregnancy. International journal of environmental research and public health. 2014;11:2958-72.

11. Derom C, Thiery E, Peeters H, Vlietinck R, Defoort P and Frijns JP. The East Flanders Prospective Twin Survey (EFPTS): an actual perception. Twin research and human genetics: the official journal of the International Society for Twin Studies. 2013;16:58-63.

12. Loos RJ, Beunen G, Fagard R, Derom C and Vlietinck R. The influence of zygosity and chorion type on fat distribution in young adult twins consequences for twin studies. Twin Res. 2001;4:356-364.

13. Vlietinck R. Determination of the zygosity of twins Leuven: Katholieke Universiteit Leuven; 1986: 1-123.

14. Loos RJ, Beunen G, Fagard R, Derom C and Vlietinck R. Birth weight and body composition in young women: a prospective twin study. Am J Clin Nutr. 2002;75:676-82.

15. Loos RJ, Fagard R, Beunen G, Derom C and Vlietinck R. Birth weight and blood pressure in young adults: a prospective twin study. Circulation. 2001;104:1633-8. 
16. Pearson $\mathrm{RL}$, Wachtel $\mathrm{H}$ and Ebi $\mathrm{KL}$. Distance-weighted traffic density in proximity to a home is a risk factor for leukemia and other childhood cancers. J Air Waste Manag Assoc. 2000;50:175-180.

17. de Boo HA and Harding JE. The developmental origins of adult disease (Barker) hypothesis. Aust N Z J Obstet Gynaecol. 2006;46:4-14.

18. Fagard RH, Celis H, Thijs L, Staessen JA, Clement DL, De Buyzere ML, et al. Daytime and nighttime blood pressure as predictors of death and cause-specific cardiovascular events in hypertension. Hypertension. 2008;51:55-61.

19. Gillman MW, Rich-Edwards JW, Rifas-Shiman SL, Lieberman ES, Kleinman KP and Lipshultz SE. Maternal age and other predictors of newborn blood pressure. J Pediatr. 2004;144:240-5.

20. Roe JJ, Thompson CW, Aspinall PA, Brewer MJ, Duff EI, Miller D, et al. Green space and stress: evidence from cortisol measures in deprived urban communities. International journal of environmental research and public health. 2013;10:4086-103.

21. van Dijk AE, van Eijsden M, Stronks K, Gemke RJ and Vrijkotte TG. The association between prenatal psychosocial stress and blood pressure in the child at age $5-7$ years. PLoS One. 2012;7:e43548.

22. Fan $F$, Zou $Y$, Tian $H$, Zhang $Y$, Zhang J, Ma $X$, et al. Effects of maternal anxiety and depression during pregnancy in Chinese women on children's heart rate and blood pressure response to stress. J Hum Hypertens. 2015:1-6.

23. Bilenko N, van Rossem L, Brunekreef B, Beelen R, Eeftens M, Hoek G, et al. Traffic-related air pollution and noise and children's blood pressure: results from the PIAMA birth cohort study. Eur J Prev Cardiol. 2015;22:4-12.

24. Sorensen $M$, Hoffmann B, Hvidberg M, Ketzel M, Jensen SS, Andersen ZJ, et al. Long-term exposure to traffic-related air pollution associated with blood pressure and self-reported hypertension in a Danish cohort. Environ Health Perspect. 2012;120:418-24.

25. Foraster M, Basagana X, Aguilera I, Rivera M, Agis D, Bouso L, et al. Association of long-term exposure to traffic-related air pollution with blood pressure and hypertension in an adult population-based cohort in Spain (the REGICOR study). Environ Health Perspect. 2014;122:404-11.

26. Dong GH, Qian ZM, Xaverius PK, Trevathan E, Maalouf S, Parker J, et al. Association between long-term air pollution and increased blood pressure and hypertension in China. Hypertension. 2013;61:578-84.

27. Chan SH, Van Hee VC, Bergen S, Szpiro AA, DeRoo LA, London SJ, et al. Long-Term Air Pollution Exposure and Blood Pressure in the Sister Study. Environ Health Perspect. 2015;123:951-8.

28. Kannan S, Misra DP, Dvonch JT and Krishnakumar A. Exposures to airborne particulate matter and adverse perinatal outcomes: a biologically plausible mechanistic framework for exploring potential effect modification by nutrition. Environ Health Perspect. $2006 ; 114: 1636-42$.

29. Foraster M, Kunzli N, Aguilera I, Rivera M, Agis D, Vila J, et al. High blood pressure and long-term exposure to indoor noise and air pollution from road traffic. Environ Health Perspect. 2014;122:1193-200.

30. Liu C, Fuertes E, Tiesler CM, Birk M, Babisch W, Bauer CP, et al. The associations between traffic-related air pollution and noise with blood 
pressure in children: results from the GINIplus and LISAplus studies. Int J Hyg Environ Health. 2014;217:499-505.

31. Hansen TW, Jeppesen J, Rasmussen S, Ibsen $\mathrm{H}$ and Torp-Pedersen C. Ambulatory blood pressure and mortality: a population-based study. Hypertension. 2005;45:499-504.

32. Li Z, Snieder H, Harshfield GA, Treiber FA and Wang X. A 15-year longitudinal study on ambulatory blood pressure tracking from childhood to early adulthood. Hypertens Res. 2009;32:404-10.

33. Lewington S, Clarke R, Qizilbash N, Peto R and Collins R. Age-specific relevance of usual blood pressure to vascular mortality: a meta-analysis of individual data for one million adults in 61 prospective studies. Lancet. 2002;360:1903-13. 

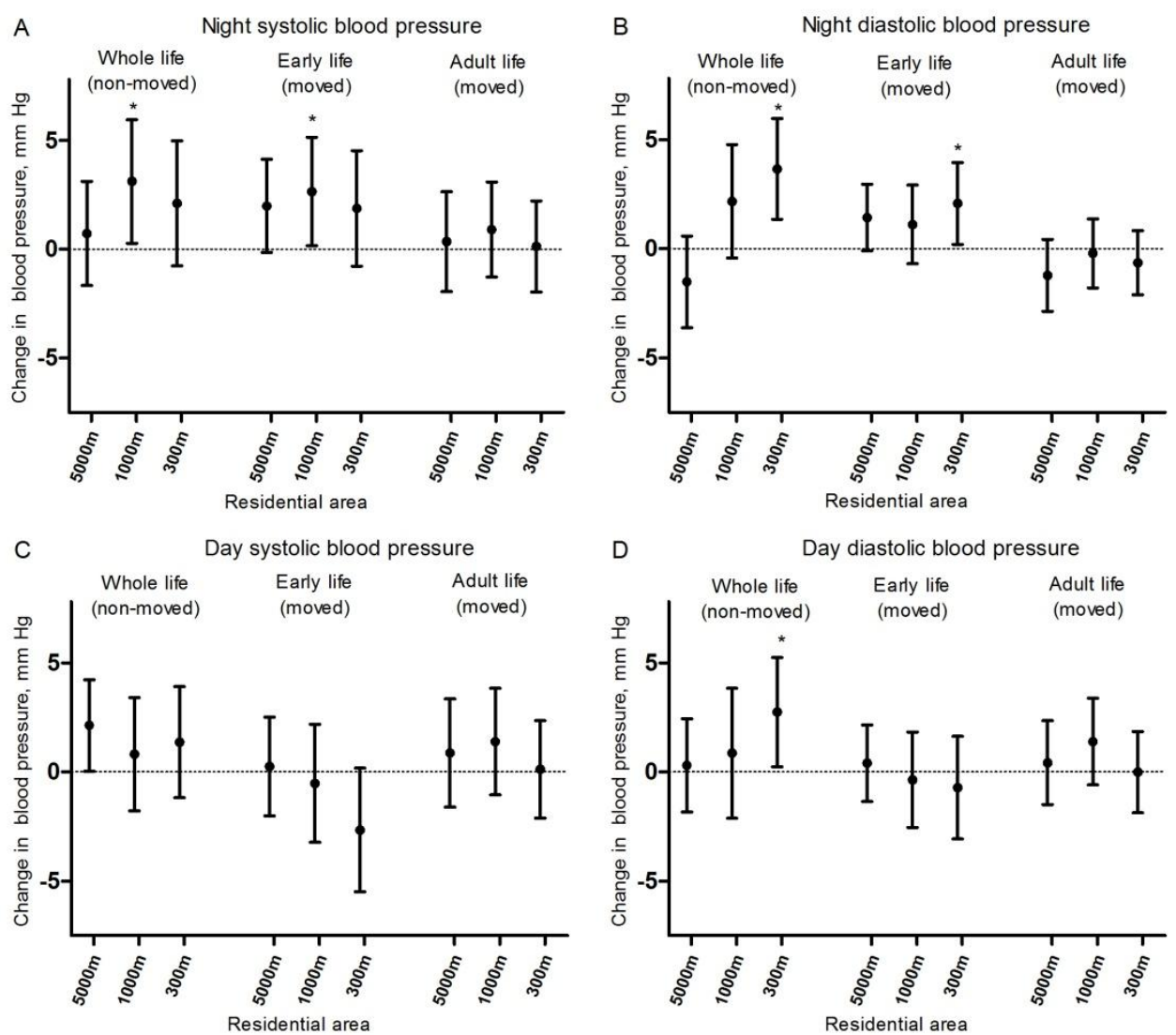

Supplement figure 1: Residential area in association with ambulatory blood pressure ( $\mathbf{m m ~ H g ) . ~ A ) ~ N i g h t ~ s y s t o l i c , ~ B ) ~ N i g h t ~ d i a s t o l i c , ~ C ) ~ D a y ~ s y s t o l i c ~ a n d ~ D ) ~ D a y ~}$ diastolic blood pressure. Adjusted for sex, gestational age, birth weight, birth year, zygosity-chorionicity group, maternal age, age, smoking, physical activity, BMI, 24h sodium and potassium, gamma-glutamyl transferase, indicators of socioeconomic status (maternal education and neighborhood household income), and smoking during pregnancy. In the twins who moved during life, we additionally adjust for residential area in adulthood/early-life. Vertical lines denote 95\% confidence intervals. *indicates significant $(p<0.05)$ change in blood pressure after an IQR increase in land use indicators. 
Night systolic blood pressure

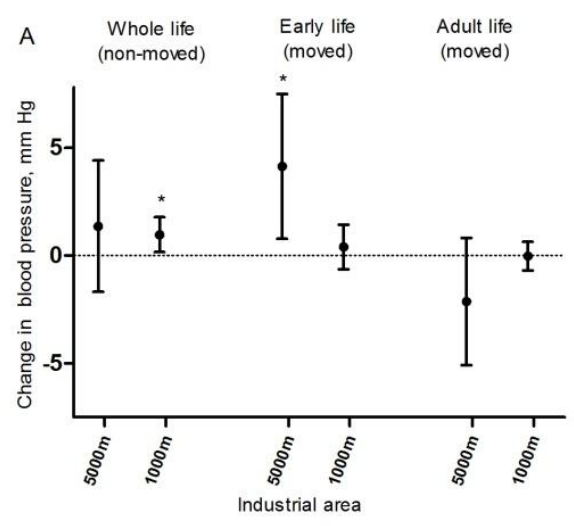

Day systolic blood pressure

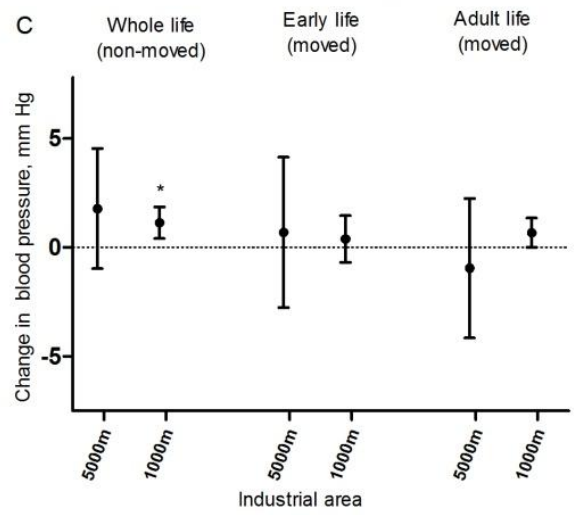

Night diastolic blood pressure

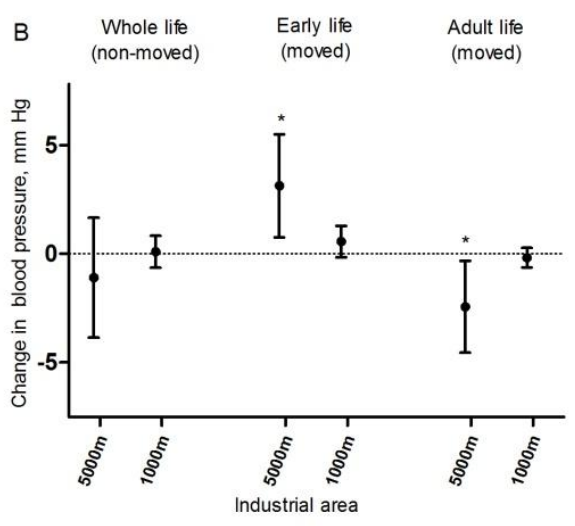

Day diastolic blood pressure

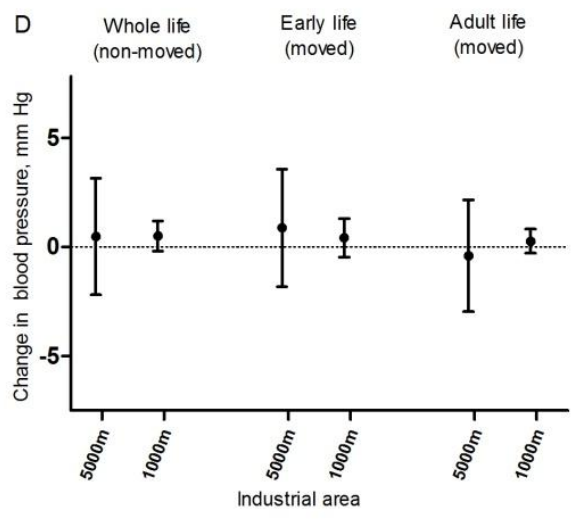

Supplement figure 2: Industrial area in association with ambulatory blood pressure ( $\mathbf{m m ~ H g}$ ) in twins. A) Night systolic, B) Night diastolic, C) Day systolic and D) Day diastolic blood pressure. Adjusted for sex, gestational age, birth weight, birth year, zygosity-chorionicity group, maternal age, age, smoking, physical activity, BMI, 24h sodium and potassium, gamma-glutamyl transferase, indicators of socioeconomic status (maternal education and neighborhood household income), and smoking during pregnancy. In the twins who moved during life, we additionally adjust for industrial area in adulthood/early-life. Vertical lines denote $95 \%$ confidence intervals. *indicates significant $(p<0.05)$ change in blood pressure after an IQR increase in land use indicators. 
CHAPTER 7

General Discussion 
In this doctoral dissertation, we assessed the effect of environmental exposure in the early-life environment of twins on outcomes both early and later in life made possible in the framework of the East Flanders Prospective Twin Survey. This register collects information at birth, examines the placenta, determines zygosity and chorionicity and takes placental tissue biopsies of twins born in East Flanders. Based on the birth address, air pollution exposure was estimated in 4760 twins born between 2002 and 2013 to study the effect on birth weight. A subset of twins participated in a follow-up study in young adulthood during which additional information and biological samples were collected and clinical examinations were performed. An estimation of the residential environmental exposure was possible due to the availability of the residential address at birth and in young adulthood at the time of the follow-up. The twins in the subset were born between 1975 till 1982 and no air pollution models were available for this time period but we were able to estimate residential traffic exposure and residential surrounding greenness using Geographic Information System (GIS) functions.

We observed that prenatal exposure to air pollution and traffic was respectively associated with a suboptimal fetal growth and a change in placental biomarkers of ageing. Besides these outcomes at birth, we noted that exposure to traffic early in life was associated with shorter telomere length in young adulthood and that surrounding greenness in early-life is associated with a lower blood pressure in adulthood. We will discuss these study findings, propose underlying mechanisms and suggest possible health implications.

\section{DISCUSSION OF THE STUDY FINDINGS}

\subsection{Birth outcomes}

Twins are already at elevated risk for low birth weight since about half of twins have low birth weight compared with $6 \%$ in singletons. ${ }^{1}$ The growth of a twin fetus differs from a singleton after 32 weeks of gestation probably due to the restricted capability of the uterine environment to nurture more than one fetus 
at a time. ${ }^{2}$ This finally results in decreased birth weight and increased odds of perinatal mortality. ${ }^{3}$ Therefore, twins could have potentially increased vulnerability to in utero exposure to air pollution.

Several studies in singletons have shown that maternal exposure to ambient air pollutants is associated with low birth weight. ${ }^{4-7} \mathrm{~A}$ European multi-cohort study observed that $\mathrm{PM}_{10}$ and $\mathrm{NO}_{2}$ are associated with increased risk of low birth weight at term. ${ }^{4}$ Besides birth weight, small for gestational age has been found associated with ambient air pollution. ${ }^{8-11}$ However, until now it is unknown to what extent particulate matter air pollution in early-life exerts its effect on birth weight and small for gestational age in twins.

We studied the association between in utero exposure to air pollution and birth weight or small for gestational age among 4,760 twins (2002-2013) of the East Flanders Prospective Twin Survey. No associations between air pollution and birth weight or small for gestational age were observed among term born twins. However, in twins born after 32-36 weeks of gestation, birth weight showed a decrease by $40.2 \mathrm{~g}$ for respectively a $10 \mu \mathrm{g} / \mathrm{m}^{3}$ increment in $\mathrm{PM}_{10}$ or $\mathrm{NO}_{2}$ during the third trimester. The corresponding estimates for $\mathrm{PM}_{10}$ and $\mathrm{NO}_{2}$ on small for gestational age, showed increased odds of 1.68 and 1.51 , respectively. These estimates are considerably higher than previously reported estimates for term born singletons.

Most studies performed in singletons only investigated term births. However, in twins more than $50 \%$ is born preterm. ${ }^{12}$ Three studies in singletons on fetal growth reduction ${ }^{13,14}$ or very low birth weight ${ }^{15}$ showed stronger effects of air pollution in preterm compared to term births. Winckelmans et al. (2015) proposed that the increased in utero time in term-born infants could possible compensate for the effects of exposure. ${ }^{14}$ Since twins achieve their optimal growth earlier in gestation, we assume that term-born twins have more time to compensate. 
Possible underlying mechanisms

Kannan et al. (2006) suggest five possible, albeit not exclusive, biologic mechanisms underlying the association between maternal exposure to particulate matter and birth outcomes. ${ }^{16}$ The mechanisms are oxidative stress, inflammation, blood coagulation, endothelial function, and hemodynamic responses which all may have an important effect on placental function (Figure 7.1). The most plausible and best studied mechanism is oxidative stress. After inhalation into the lungs, phagocytosis of particulate matter by alveolar macrophages can result in oxidative stress and inflammation. ${ }^{17}$ The very fine particles can even translocate into the mother's blood circulation, ${ }^{18}$ be transported to the placenta and influence placental growth and function. ${ }^{19}$ The placenta is not only a mediator between the mother's environmental exposure and the fetus, but also managed nutrient and oxygen transfer, key determinants of fetal growth.

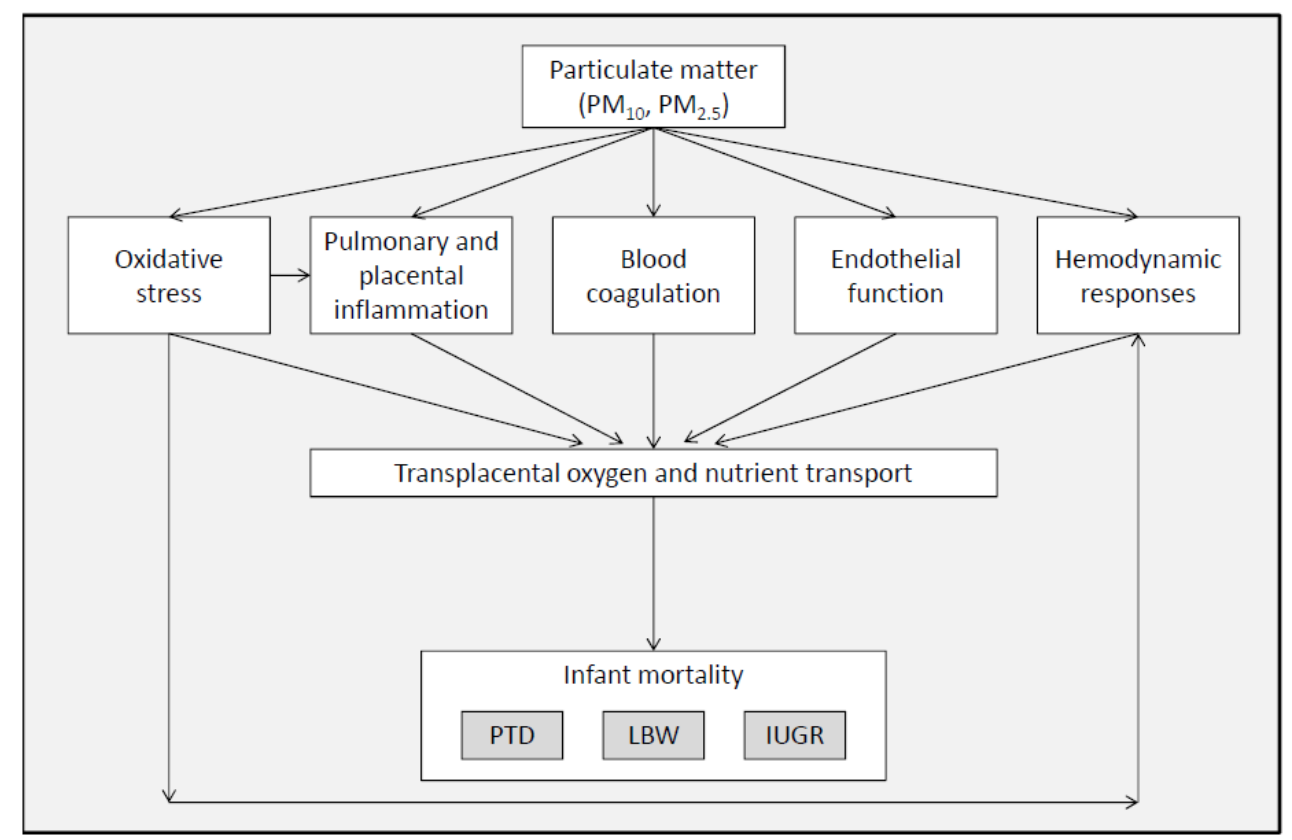

Figure 7.1. Possible biological pathways between exposure to particulate matter and birth outcomes adapted from Kannan et al., 2006. ${ }^{16}$ PTD, preterm delivery (PTD); LBW, low birth weight; IUGR, intrauterine growth retardation. 
Health implications later in life

The Developmental Origins of Health and Disease hypothesis, often called the 'Barker hypothesis', states that adverse influences in the early-life environment can result in increased disease risk in adulthood. ${ }^{20}$ Barker's work in the $1990 \mathrm{~s}$ showed an association between low birth weight and several diseases. ${ }^{21-27}$ This is confirmed in more recent studies showing an association between low birth weight with an increase risk in the development of insulin-resistance syndrome, $^{28}$ hypertension, ${ }^{29}$ cardiovascular diseases, ${ }^{28}$ and cardiovascular mortality. ${ }^{30}$ The association of birth weight with cardiovascular risk ${ }^{31}$ and adult blood pressure 32,33 is also observed in twins. This suggests that, although intrauterine growth in twins is different from that in singletons, birth weight in twins is also relevant to the development of cardiovascular disease. ${ }^{31}$

Various causal pathways that have been hypothesized as mechanisms underlying the association between birth weight and disease development are described by Jaddoe and Witterman (2006). They proposed central roles for fetal undernutrition, increased cortisol exposure, genetic susceptibility and accelerated post-natal growth. ${ }^{34}$ In addition to birth outcomes, we have investigated another mechanism that may link traffic related air pollution during gestation with disease outcome later in life, i.e. cellular ageing.

\subsection{Biomarkers of ageing}

\subsubsection{Mitochondrial DNA content}

Traffic exposure is an important environmental source of reactive oxygen generating species. ${ }^{35}$ Mitochondrial DNA is vulnerable for oxidative damage due the lack of protective histones and a less efficient DNA repair system compared to nuclear DNA. ${ }^{36}$ With advanced age, mutations and oxidative damage in mitochondrial DNA accumulates and causes a decrease in functionality. ${ }^{37}$

A small number of studies showed an effect of air pollution on mitochondrial DNA content, however, opposite directions of response to exposure were also observed. Among healthy steelworkers a positive association between long-term 
particulate matter exposure and mitochondrial DNA in blood was observed, ${ }^{38}$ whereas blood mitochondrial DNA content was inversely associated with 8-day average ambient $\mathrm{PM}_{10}$ concentrations in office workers. ${ }^{39} \mathrm{NO}_{2}$ exposure during pregnancy ${ }^{40}$ and $\mathrm{PM}_{10}$ exposure during the last month of pregnancy ${ }^{41}$ were inversely associated with placental mitochondrial DNA content of singletons. Mediation analysis suggested that $10 \%$ of the association between prenatal $\mathrm{NO}_{2}$ and birth weight was mediated by changes in placental mtDNA content. ${ }^{40}$

We investigated the relative importance of genetic and environmental sources on the variance of mitochondrial DNA content in placental tissue among 179 twins. In addition we studies the association between maternal residential traffic exposure and surrounding greenness with placental mitochondrial DNA content. We noted that mitochondrial DNA content was mainly determined by the common environment, while genetic factors appeared to play a minor role. We showed that lower residential surrounding greenness and an increased distance between the maternal residence and the nearest major road is associated with a lower mitochondrial DNA content at birth. A doubling in the residential distance to the nearest major road was associated with a relative decrease of placental mitochondrial DNA content of $8.3 \%$. For an interquartile range increase $(22 \%)$ in maternal residential surrounding greenness in a $5000 \mathrm{~m}$ radius, mitochondrial DNA content was $10.0 \%$ lower. The association between residential greenness and mitochondrial DNA content remained significant in smaller buffer sizes.

This is the first study to show that maternal surrounding greenness is associated with a decrease in mitochondrial DNA content in placental tissue. In contrast to other studies investigating air pollution exposure during pregnancy that noted a decrease in placental mitochondrial DNA content, ${ }^{40,41}$ we observed that residential traffic exposure is associated with an higher placental mitochondrial DNA content. This discrepancy can possibly be explained by sampling location on the placenta resulting in a different cell composition since differential mitochondrial features have been observed in placental intrauterine growth restriction depending on the cell lineage. ${ }^{42}$ 
Possible underlying mechanism

As previously mentioned, air pollution and traffic can entail oxidative stress and inflammation in placental tissue. Oxidative stress will stimulate mitochondrial proliferation and mitochondrial DNA copy number to supply more energy to meet the need for cell survival. However, when the capacity of the antioxidant system is compromised, excess production of reactive oxygen species (ROS) will result in defective mitochondria and mutated DNA, and a cyclic increase in ROS production and oxidative damage. This will also cause excess ROS production and further oxidative damage. ${ }^{43}$

Health implications later in life

The consequences of an altered placental mitochondrial DNA content on the mitochondrial DNA content later in life are currently unknown. However, it could be possible that this has an effect on ageing and the development of diseases later in life such as cancer and metabolic disorders. ${ }^{44}$

\subsubsection{Telomere length}

Besides mitochondrial DNA content, we also studied telomere length, an established biomarker of ageing. Cross-sectional studies comparing individuals with a wide age range from neonates to elderly, observed that the rate of telomere attrition varied at different ages ${ }^{45,46}$ and that telomere attrition was extremely rapid in the first year and continued thereafter at a slower rate. ${ }^{46}$ This suggest, that early-life is an important period in the determination of telomere length.

In adults, long-term exposure to traffic has been linked to shorter telomeres. ${ }^{47,48}$ Leukocyte telomere length in traffic officers is shorter compared to office workers ${ }^{47}$ and long-term exposure to airborne particles, especially those related to traffic, is associated with faster telomere attrition in 70-year olds. ${ }^{48}$ However, the impact of early-life exposure on telomere length in placenta and on telomere length later in life is not studied until now. 
We investigated the effect of in utero exposure to traffic and greenness on telomere length in placenta tissue of 211 twins. Variation in telomere length in placental tissue is mainly determined by the common environment. We showed that maternal residential proximity to traffic was associated with shorter telomeres in placental tissue and that an increase in maternal surrounding greenness is associated with longer telomeres in placental tissue. A doubling of the distance between the residence and the nearest major road was associated with an increase of $5.3 \%$ in placental telomere length. A 3.6\% significant increase in telomere length was observed with an interquartile (22\%) increase in greenness in a $5000 \mathrm{~m}$ radius.

Additionally, we investigated telomere length in buccal cells in young adulthood among 205 twins. We observed a strong association between placental telomere length and the telomere length in buccal cells taken at an average age of 23 year. In addition, we also observed that traffic exposure early in life is associated with telomere length in young adulthood among twins who were not living at their birth address at time of the measurement. Twins living further away from a major road at the birth address (doubling) had $2.6 \%$ longer telomeres. We even observed that persons with a high traffic exposure early in life had a decline in ranking of telomere length between birth and adulthood. However, no effects of surrounding greenness in early-life on telomere length later in life were noted.

Surrounding greenness was only associated with placental telomere length suggesting that the presence of greenness in early-life has no lasting effects on telomere length. This suggest that the underlying pathway between greenness and telomere length differs from that of traffic exposure and telomere length. Indeed, we observed that traffic exposure early in life not only has an effect on placental telomere length but also on telomere length at adult age measured in buccal cells. These results do not only indicate the importance of early-life exposure but they also suggest that telomere length may serve as a possible underlying mechanism between early-life exposure and potential disease outcome later in life. 
Possible underlying mechanism

Similar to mitochondrial DNA content, we assume that the underlying mechanism between traffic exposure and telomere length is oxidative stress. Telomeres are highly sensitive to oxidative stress due to their high guanine content and the deficient repair system of single-strand breaks. ${ }^{49}$

However, the underlying mechanism between exposure to greenness and telomere length can also be the result of maternal psychological stress since higher levels of green space in residential neighbourhoods are linked with lower perceived stress and healthier cortisol levels. ${ }^{50}$ Maternal psychological stress during pregnancy is linked with newborn leukocyte telomere length ${ }^{51}$ and even with telomere length in young adulthood. ${ }^{52}$ These studies suggest that prenatal psychological stress could affect telomere length in the newborn trough several interrelated biological pathways. The first pathway is transplacental transport of the stress hormone cortisol. Second, is the release of placental hormones such as placental corticotrophin-releasing hormone. Third, is the induction of an altered placental physiology including blood flow and metabolism. The fourth suggested pathway deals with effects on the developing immune system. And finally, stress hormones and insulin may induce inflammation and oxidative stress mediators.

\section{Health implications later in life}

Longitudinal studies in adults showed that telomere ranking is stable during adulthood, ${ }^{53}$ suggesting that the effects in young adulthood also remain later in adult life. Hence, telomere length is concidered as a marker of the biological ageing process ${ }^{54}$ and a general risk factor for age-related diseases in adults and elderly. We assume that short telomere length in young adult will result in an increased risk of diseases, such as cardiovascular disease, ${ }^{55}$ diabetes mellitus, ${ }^{56}$ and cancer. ${ }^{57,58}$ 


\subsection{Greenness in early-life and blood pressure in young adulthood}

High blood pressure is the leading risk factor for cardiovascular disease and mortality in the world. ${ }^{59,60}$ Risk factors for high blood pressure are not limited to adulthood but can also originate from early-in-life perturbations such as birth weight ${ }^{22}$ and maternal smoking. ${ }^{61}$ We investigated the effects of residential traffic exposure and presence of residential greenness in the early-life on ambulatory blood pressure in young adulthood.

Long-term exposure to air pollution has been associated with blood pressure. ${ }^{62}$ In addition, a meta-analysis showed a weak positive association between high traffic exposure within $100 \mathrm{~m}$ of the residence and systolic or diastolic blood pressure. ${ }^{63} \mathrm{~A}$ negative association between greenness and blood pressure was observed in the limited number of studies conducted. Among 10 year-old children living in an urbanised area, low residential greenness was associated with higher blood pressure. ${ }^{64}$ Similar results were observed in a Dutch study showing that living in a neighbourhood with a high quality of green space was associated with a lower systolic blood pressure and lower odds of hypertension. ${ }^{65}$ In addition, among 3416 pregnant women an association was observed between proximity of the place of residence to green spaces and lower blood pressure. ${ }^{66}$

In our study, ambulatory (24-hour) blood pressure of 278 twins was obtained at the age of 18 to 25 years. Among twins who were not living at their birth address at time of the measurement $(n=181)$, night-time blood pressure was inversely associated with residential surrounding greenness in early-life, while adjusting for residential greenness exposure in adulthood. An interquartile increase in residential greenness exposure in early-life (5000 $\mathrm{m}$ radius) was significantly $(p=0.04)$ associated with a $2.42 \mathrm{mmHg}$ decrease in adult night systolic blood pressure. We found no significant effect of adult residential greenness with adult blood pressure, while accounting for the early-life greenness exposure. Traffic exposure in early-life was not associated with adult blood pressure. 
Changes in blood pressure in association with greenness exposure during earlylife were noted during the night and not during the day. A possible reason can be that blood pressure is more variable during the day and more related to basal blood pressure during the night. We did not observe any effect of traffic exposure during early-life on blood pressure. This suggest that exposure to greenness has other beneficial effects, besides reduced air pollution and traffic exposure, that may influence blood pressure later in life. A possible mechanism could be perceived stress.

\section{Possible underlying mechanism}

An underlying mechanism between surrounding greenness in early-life and blood pressure in young adulthood may be stress. Higher levels of green space in residential neighbourhood, are linked with lower perceived stress and a healthier cortisol levels in women in a deprived urban population. ${ }^{50}$ Moreover, prenatal maternal psychological status has an effect on blood pressure in their offspring at the age of 5-7 years ${ }^{67}$ and blood pressure response to stress at the age of 79 years. $^{68}$

Stress exposure in the mother will activate the the hypothalamic-pituitaryadrenal axis (HPA axis), resulting in the release of multiple hormones, including cortisol. ${ }^{69}$ Fetuses are protected from higher maternal cortisol concentrations by the placental enzyme 11ß-hydroxysteroid dehydroxysteroid dehydrogenase-type 2 (11ß-HSD2) that can covert cortisol to inactive cortisone. ${ }^{69}$ Animal models show that an acute stressor will up-regulated this enzyme, while chronic maternal stress reduced the capacity to react to acute stress. ${ }^{70}$ Inhibition of $11 \beta-H S D$ throughout the pregnancy of rats results in low birth weight and elevated blood pressure in the adult offspring. ${ }^{71}$

\section{Health implications later in life}

The changes in blood pressure observed in young adulthood may have implications for blood pressure later in life since increased blood pressure in childhood can be persistent. ${ }^{72}$ Even findings of a small reduction in blood pressure may have a major impact in reducing morbidity and mortality. ${ }^{73}$ 
Lowering systolic blood pressure by $2 \mathrm{~mm} \mathrm{Hg}$ at the population level would result in an $10 \%$ overall reduction in mortality from stroke and about $7 \%$ lower mortality from ischemic heart disease or other vascular causes in middle age. ${ }^{73}$

\section{EARLY-LIFE EXPOSURE AND DISEASE OUTCOME LATER IN LIFE}

We hypothesize that early-life exposure to air pollution, traffic, and a reduction in surrounding greenness may result in disease development later in life. Our findings are currently insufficient to confirm this hypothesis. Due the young age of the study population at follow-up, aged-related diseases where not fully developed yet. However, an additional follow-up of the same study population at a more advanced age could provide evidence to lend support to our hypothesis.

Despite the young age of our study population, we already observed changes due to environmental exposure in the early-life that may lead to disease development. We noted that an adverse early environment not only resulted in low birth weight but also in shorter telomere length and an increased ambulatory blood pressure in young adulthood. All these changes are linked in literature to disease outcome as earlier described. However, the underlying biological pathways are not fully understood and it is still unclear if these outcomes all share one common pathway or if they are the result of different mechanisms.

Tarry-Adkins and Ozanne (2011) suggest three mechanisms by which a phenomenon occurring in early-life may have long-term effects and result in disease development. ${ }^{74}$ The first mechanism is that suboptimal concentrations of an important factor during a critical period of development will result in permanent biological changes. The second mechanism is epigenetic modifications leading to changes in gene expression. The third mechanism is by permanent effect on the regulation of cellular ageing, for example telomere length. 
We add to this a fourth item which is mental stress exposure.Based on our evidence, we would expect that telomere length and cellular ageing play a key role in health outcomes originating in the early-life environment. However, based on the result of residential greenness on ambulatory blood pressure we expect that psychological stress as a result of the environment also play an important role. Since, no information on psychological stress or biomarkers of stress such as cortisol are available at birth in this study group, a new birth cohort study with information on psychological stress and greenness could shed insight into this molecular pathway.

\section{NATURE VS NURTURE}

Twin studies provide the opportunity to investigate the relative contributions of nature and nurture to phenotypes by comparing the resemblance of monozygotic and dizygotic twins. Beyond genetic predisposition (=nature), agerelated diseases can find their origin in the early-life environment (=nurture).

This twin study shows the importance of nurture in early-life on biomarkers of ageing in placental tissue. We showed that placental mitochondrial DNA content and placental telomere length are mainly determined by the common environment, while genetic factors appeared to play a minor role.

In contrast to nature, the main advantage of nurture is that a person is capable of altering this environment. The elucidation of the importance of nurture in an ageing-related pathway can stimulate persons to improve their environment resulting in a possible decrease in age-related diseases. 


\section{REFERENCES}

1. Martin JA, Hamilton BE, Osterman MJ, Curtin SC, Mathews MA and Mathews TJ. Births: final data for 2012. National vital statistics reports: from the Centers for Disease Control and Prevention, National Center for Health Statistics, National Vital Statistics System. 2013;62:1-27.

2. Blickstein I. Intrauterine Growth. In: L. Keith, ed. Multiple pregnanciy: epidemiology, gestation \& perinatal outcome New York: The Parthenon Publishing Group; 1995: 503-513.

3. Hack KE, Derks JB, Elias SG, Franx A, Roos EJ, Voerman SK, et al. Increased perinatal mortality and morbidity in monochorionic versus dichorionic twin pregnancies: clinical implications of a large Dutch cohort study. BJOG : an international journal of obstetrics and gynaecology. 2008; 115:58-67.

4. Pedersen M, Giorgis-Allemand L, Bernard C, Aguilera I, Andersen A-M, Ballester $F$, et al. Ambient air pollution and low birthweight: a European cohort study (ESCAPE). Lancet Respir Med. 2013;1:695-704.

5. Dadvand $P$, Parker J, Bell ML, Bonzini M, Brauer M, Darrow LA, et al. Maternal exposure to particulate air pollution and term birth weight: a multi-country evaluation of effect and heterogeneity. EnvironHealth Perspect. 2013;121:267-373.

6. Sapkota A, Chelikowsky AP, Nachman KE, Cohen AJ and Ritz B. Exposure to particulate matter and adverse birth outcomes: a comprehensive review and meta-analysis. Air Qual Atmos HIth. 2012;5:369-381.

7. Stieb DM, Chen L, Eshoul M and Judek S. Ambient air pollution, birth weight and preterm birth: a systematic review and meta-analysis. Environmental research. 2012;117:100-11.

8. van den Hooven $\mathrm{EH}$, Pierik $\mathrm{FH}$, de Kluizenaar $\mathrm{Y}$, Willemsen SP, Hofman A, van Ratingen SW, et al. Air pollution exposure during pregnancy, ultrasound measures of fetal growth, and adverse birth outcomes: a prospective cohort study. Environ Health Perspect. 2012;120:150-6.

9. Le HQ, Batterman SA, Wirth JJ, Wahl RL, Hoggatt KJ, Sadeghnejad A, et al. Air pollutant exposure and preterm and term small-for-gestationalage births in Detroit, Michigan: long-term trends and associations. Environment international. 2012;44:7-17.

10. Mannes T, Jalaludin B, Morgan G, Lincoln D, Sheppeard V and Corbett S. Impact of ambient air pollution on birth weight in Sydney, Australia. Occupational and environmental medicine. 2005;62:524-30.

11. Liu S, Krewski D, Shi Y, Chen $Y$ and Burnett RT. Association between maternal exposure to ambient air pollutants during pregnancy and fetal growth restriction. Journal of exposure science \& environmental epidemiology. 2007;17:426-32.

12. Cammu HM, E.; Martens, G.; Van Mol, C.; Jacquemyn Y. Perinatale activiteiten in Vlaanderen 2013. 2014.

13. Pereira G, Cook AG, Haggar F, Bower C and Nassar N. Locally derived traffic-related air pollution and fetal growth restriction: a retrospective cohort study. Occupational and environmental medicine. 2012;69:81522. 
14. Winckelmans E, Cox B, Martens E, Nemery B and Nawrot TS. Fetal growth and maternal exposure to particulate air pollution; More marked effects at lower exposure and modification by gestational duration. Submitted.

15. Rogers JF and Dunlop AL. Air pollution and very low birth weight infants: a target population? Pediatrics. 2006;118:156-64.

16. Kannan S, Misra DP, Dvonch JT and Krishnakumar A. Exposures to airborne particulate matter and adverse perinatal outcomes: a biologically plausible mechanistic framework for exploring potential effect modification by nutrition. Environ Health Perspect. 2006; $114: 1636-42$.

17. Sijan Z, Antkiewicz DS, Heo J, Kado NY, Schauer JJ, Sioutas C, et al. An In Vitro alveolar macrophage assay for the assessment of inflammatory cytokine expression induced by atmospheric particulate matter. Environ Toxicol. 2015;30:836-51.

18. Nemmar A, Hoet PH, Vanquickenborne B, Dinsdale D, Thomeer M, Hoylaerts MF, et al. Passage of inhaled particles into the blood circulation in humans. Circulation. 2002;105:411-414.

19. Wick P, Malek A, Manser P, Meili D, Maeder-Althaus X, Diener L, et al. Barrier capacity of human placenta for nanosized materials. EnvironHealth Perspect. 2010;118:432-436.

20. de Boo HA and Harding JE. The developmental origins of adult disease (Barker) hypothesis. Aust N Z J Obstet Gynaecol. 2006;46:4-14.

21. Osmond $\mathrm{C}$ and Barker DJ. Fetal, infant, and childhood growth are predictors of coronary heart disease, diabetes, and hypertension in adult men and women. Environ Health Perspect. 2000;108 Suppl 3:545-53.

22. Barker DJ, Bull AR, Osmond $C$ and Simmonds SJ. Fetal and placental size and risk of hypertension in adult life. BMJ (Clinical research ed). 1990;301:259-62.

23. Barker DJ. The fetal and infant origins of adult disease. BMJ (Clinical research ed). 1990;301:1111.

24. Barker DJ. Fetal origins of coronary heart disease. BMJ (Clinical research ed). $1995 ; 311: 171-4$.

25. Barker DJ and Osmond C. Infant mortality, childhood nutrition, and ischaemic heart disease in England and Wales. Lancet. 1986;1:1077-81.

26. Barker DJ. Intrauterine programming of coronary heart disease and stroke. Acta Paediatr Suppl. 1997;423:178-82; discussion 183.

27. Barker DJ, Winter PD, Osmond C, Margetts B and Simmonds SJ. Weight in infancy and death from ischaemic heart disease. Lancet. 1989;2:57780.

28. Levy-Marchal C and Jaquet D. Long-term metabolic consequences of being born small for gestational age. Pediatric diabetes. 2004;5:147-53.

29. Mu M, Wang SF, Sheng J, Zhao Y, Li HZ, Hu CL, et al. Birth weight and subsequent blood pressure: a meta-analysis. Arch Cardiovasc Dis. 2012;105:99-113.

30. Risnes KR, Vatten LJ, Baker JL, Jameson K, Sovio U, Kajantie E, et al. Birthweight and mortality in adulthood: a systematic review and metaanalysis. Int J Epidemiol. 2011;40:647-61.

31. Ijzerman RG, Boomsma DI and Stehouwer CD. Intrauterine environmental and genetic influences on the association between 
birthweight and cardiovascular risk factors: studies in twins as a means of testing the fetal origins hypothesis. Paediatric and perinatal epidemiology. 2005;19 Suppl 1:10-4.

32. Loos RJ, Fagard R, Beunen G, Derom C and Vlietinck R. Birth weight and blood pressure in young adults: a prospective twin study. Circulation. 2001;104:1633-8.

33. Poulter NR, Chang CL, MacGregor AJ, Snieder $H$ and Spector TD. Association between birth weight and adult blood pressure in twins: historical cohort study. BMJ (Clinical research ed). 1999;319:1330-3.

34. Jaddoe VW and Witteman JC. Hypotheses on the fetal origins of adult diseases: contributions of epidemiological studies. Eur $\mathrm{J}$ Epidemiol. 2006;21:91-102.

35. Lai CH, Liou SH, Lin HC, Shih TS, Tsai PJ, Chen JS, et al. Exposure to traffic exhausts and oxidative DNA damage. Occupational and environmental medicine. 2005;62:216-22.

36. Liu $\mathrm{P}$ and Demple $\mathrm{B}$. DNA repair in mammalian mitochondria: Much more than we thought? Environmental and molecular mutagenesis. 2010;51:417-26.

37. Chistiakov DA, Sobenin IA, Revin VV, Orekhov AN and Bobryshev YV. Mitochondrial aging and age-related dysfunction of mitochondria. BioMed research international. 2014;2014:238463.

38. Hou L, Zhu ZZ, Zhang X, Nordio F, Bonzini M, Schwartz J, et al. Airborne particulate matter and mitochondrial damage: a cross-sectional study. Environmental health : a global access science source. 2010;9:48.

39. Hou L, Zhang X, Dioni L, Barretta F, Dou C, Zheng $Y$, et al. Inhalable particulate matter and mitochondrial DNA copy number in highly exposed individuals in Beijing, China: a repeated-measure study. Particle and fibre toxicology. 2013;10:17.

40. Clemente DB, Casas M, Vilahur N, Begiristain $H$, Bustamante $M$, Carsin $A E$, et al. Prenatal Ambient Air Pollution, Placental Mitochondrial DNA Content, and Birth Weight in the INMA (Spain) and ENVIRAGE (Belgium) Birth Cohorts. Environ Health Perspect. 2015.

41. Janssen BG, Munters E, Pieters N, Smeets K, Cox B, Cuypers A, et al. Placental mitochondrial DNA content and particulate air pollution during in utero life. Environ Health Perspect. 2012;120:1346-1352.

42. Mando C, De Palma C, Stampalija T, Anelli GM, Figus M, Novielli C, et al. Placental mitochondrial content and function in intrauterine growth restriction and preeclampsia. American journal of physiology Endocrinology and metabolism. 2014;306:E404-13.

43. Lee $\mathrm{HC}$ and Wei $\mathrm{YH}$. Mitochondrial biogenesis and mitochondrial DNA maintenance of mammalian cells under oxidative stress. The international journal of biochemistry \& cell biology. 2005;37:822-34.

44. Malik AN and Czajka A. Is mitochondrial DNA content a potential biomarker of mitochondrial dysfunction? Mitochondrion. 2013;13:48192.

45. Frenck RW, Jr., Blackburn EH and Shannon KM. The rate of telomere sequence loss in human leukocytes varies with age. ProcNatIAcadSciUSA. 1998;95:5607-5610.

46. Rufer N, Brummendorf TH, Kolvraa S, Bischoff C, Christensen K, Wadsworth $\mathrm{L}$, et al. Telomere fluorescence measurements in 
granulocytes and T lymphocyte subsets point to a high turnover of hematopoietic stem cells and memory $\mathrm{T}$ cells in early childhood. $J$ Exp Med. 1999;190:157-67.

47. Hoxha M, Dioni L, Bonzini M, Pesatori AC, Fustinoni S, Cavallo D, et al. Association between leukocyte telomere shortening and exposure to traffic pollution: a cross-sectional study on traffic officers and indoor office workers. EnvironHealth. 2009;8:41.

48. McCracken J, Baccarelli A, Hoxha M, Dioni L, Melly S, Coull B, et al. Annual ambient black carbon associated with shorter telomeres in elderly men: Veterans Affairs Normative Aging Study. EnvironHealth Perspect. 2010;118:1564-1570.

49. von Zglinicki T. Role of oxidative stress in telomere length regulation and replicative senescence. AnnNYAcadSci. 2000;908:99-110.

50. Roe JJ, Thompson CW, Aspinall PA, Brewer MJ, Duff EI, Miller D, et al. Green space and stress: evidence from cortisol measures in deprived urban communities. International journal of environmental research and public health. 2013;10:4086-103.

51. Entringer S, Epel ES, Lin J, Buss C, Shahbaba B, Blackburn EH, et al. Maternal psychosocial stress during pregnancy is associated with newborn leukocyte telomere length. American journal of obstetrics and gynecology. 2013;208:134 e1-7.

52. Entringer S, Epel ES, Kumsta R, Lin J, Hellhammer DH, Blackburn EH, et al. Stress exposure in intrauterine life is associated with shorter telomere length in young adulthood. ProcNatIAcadSciUSA. 2011;108:E513-E518.

53. Benetos A, Kark JD, Susser E, Kimura M, Sinnreich R, Chen W, et al. Tracking and fixed ranking of leukocyte telomere length across the adult life course. Aging Cell. 2013;12:615-21.

54. Sanders JL and Newman AB. Telomere length in epidemiology: a biomarker of aging, age-related disease, both, or neither? Epidemiol Rev. 2013;35:112-31.

55. Haycock PC, Heydon E, Kaptoge S, Butterworth AS, Thompson A and Willeit $P$. Leucocyte telomere length and risk of cardiovascular disease: systematic review and meta-analysis. BMJ (Clinical research ed). 2014;349.

56. Zhao J, Miao K, Wang $\mathrm{H}$, Ding $\mathrm{H}$ and Wang DW. Association between telomere length and type 2 diabetes mellitus: a meta-analysis. PLoS One. 2013;8:e79993.

57. Wentzensen IM, Mirabello L, Pfeiffer RM and Savage SA. The association of telomere length and cancer: a meta-analysis. Cancer epidemiology, biomarkers \& prevention : a publication of the American Association for Cancer Research, cosponsored by the American Society of Preventive Oncology. 2011;20:1238-50.

58. Ma H, Zhou Z, Wei S, Liu Z, Pooley KA, Dunning AM, et al. Shortened telomere length is associated with increased risk of cancer: a metaanalysis. PLoS One. 2011;6:e20466.

59. Colin Mathers GS, Maya Mascarenhas. Global Health Risks: Mortality and burden of disease attributable to selected major risks. 2009:70.

60. WHO. Global atlas on cardiovascular disease prevention and control Policies, strategies and interventions. 2011:1+4. 
61. Hogberg L, Cnattingius S, Lundholm C, D'Onofrio BM, Langstrom N and Iliadou AN. Effects of maternal smoking during pregnancy on offspring blood pressure in late adolescence. J Hypertens. 2012;30:693-9.

62. Fuks K, Moebus S, Hertel S, Viehmann A, Nonnemacher M, Dragano N, et al. Long-term urban particulate air pollution, traffic noise, and arterial blood pressure. Environ Health Perspect. 2011;119:1706-11.

63. Fuks KB, Weinmayr G, Foraster M, Dratva J, Hampel R, Houthuijs D, et al. Arterial blood pressure and long-term exposure to traffic-related air pollution: an analysis in the European Study of Cohorts for Air Pollution Effects (ESCAPE). Environ Health Perspect. 2014;122:896-905.

64. Markevych I, Thiering E, Fuertes E, Sugiri D, Berdel D, Koletzko S, et al. A cross-sectional analysis of the effects of residential greenness on blood pressure in 10-year old children: results from the GINIplus and LISAplus studies. BMC Public Health. 2014;14:477.

65. Agyemang C, van Hooijdonk C, Wendel-Vos W, Ujcic-Voortman JK, Lindeman $E$, Stronks $K$, et al. Ethnic differences in the effect of environmental stressors on blood pressure and hypertension in the Netherlands. BMC Public Health. 2007;7:118.

66. Grazuleviciene R, Dedele A, Danileviciute A, Vencloviene J, Grazulevicius $T$, Andrusaityte $S$, et al. The influence of proximity to city parks on blood pressure in early pregnancy. International journal of environmental research and public health. 2014;11:2958-72.

67. van Dijk AE, van Eijsden M, Stronks K, Gemke RJ and Vrijkotte TG. The association between prenatal psychosocial stress and blood pressure in the child at age 5-7 years. PLoS One. 2012;7:e43548.

68. Fan $\mathrm{F}$, Zou $\mathrm{Y}$, Tian $\mathrm{H}$, Zhang $\mathrm{Y}$, Zhang J, Ma X, et al. Effects of maternal anxiety and depression during pregnancy in Chinese women on children's heart rate and blood pressure response to stress. J Hum Hypertens. 2015:1-6.

69. Beijers R, Buitelaar JK and de Weerth C. Mechanisms underlying the effects of prenatal psychosocial stress on child outcomes: beyond the HPA axis. Eur Child Adolesc Psychiatry. 2014;23:943-56.

70. Welberg LA, Thrivikraman KV and Plotsky PM. Chronic maternal stress inhibits the capacity to up-regulate placental 11beta-hydroxysteroid dehydrogenase type 2 activity. The Journal of endocrinology. 2005;186:R7-R12.

71. Lindsay RS, Lindsay RM, Edwards CR and Seckl JR. Inhibition of 11-betahydroxysteroid dehydrogenase in pregnant rats and the programming of blood pressure in the offspring. Hypertension. 1996;27:1200-4.

72. Chen $X$ and Wang $Y$. Tracking of blood pressure from childhood to adulthood: a systematic review and meta-regression analysis. Circulation. 2008;117:3171-80.

73. Lewington S, Clarke R, Qizilbash N, Peto R and Collins R. Age-specific relevance of usual blood pressure to vascular mortality: a meta-analysis of individual data for one million adults in 61 prospective studies. Lancet. 2002;360:1903-13.

74. Tarry-Adkins JL and Ozanne SE. Mechanisms of early life programming: current knowledge and future directions. $A m \mathrm{~J}$ Clin Nutr. 2011;94:1765S-1771S. 
Appendices 



\section{Valorisation}




\section{Valorisation}

Our research shows the importance of the early-life environment. We observed that prenatal exposure to air pollution and traffic was respectively associated with a suboptimal fetal growth and a change in placental biomarkers of ageing. Besides these outcomes at birth, we noted that exposure to traffic early in life was associated with shorter telomere length in young adulthood and that surrounding greenness in early-life is associated with a lower blood pressure in adulthood. These results may lend support to policy makers trying to built an healthier living environment to protect human health by improving air quality, reducing the numbers of cars or their emission and by increasing and improving green spaces. These measures may not only result in a small improvement of health on an individual level but can also have a large impact on population level since every individual of the population is exposed to traffic and air pollution. Valorisation or the creation of value out of this knowledge is not only based on a social level by improving health but also on a economic level by reducing costs.

\section{Economic cost of air pollution in Europe}

Ambient air pollution causes global health impacts ${ }^{1-3}$ and is, according to the World Health Organization (WHO), responsible for approximately 3.7 million premature deaths worldwide in $2012 . .^{4}$ Air pollution is the number one environmental cause of death in the European Union (EU) and is according to the European Commission responsible for 406,000 annual premature deaths in 2010 , ten times more than from road traffic accidents. ${ }^{5}$

The European Commission estimate that external cost associated with main health impacts in the European Union due to air pollution range between $€ 330$ billion and $€ 940$ billion each year depending on whether the low or high range of possible impact valuations is taken. ${ }^{5}$ Table 1 summarizes the estimated costs due to air pollution in Europe. These costs include not only the impact on the health of citizens who experience it, but also direct economic costs. Air pollution causes more than 100 million workdays lost per year across Europe, with an economic damage in the range of $€ 15$ billion due to productivity losses. Although a full quantification remains challenging, healthcare costs are estimated in the 
order of $€ 4$ billion every year for the treatment of air-pollution-related chronic bronchitis alone, with total costs likely to be substantially higher.

The Organization of Economic Cooperation and Development (OECD) estimates the cost of deaths in 24 European OECD countries (21 EU member-states plus Iceland, Norway and Switzerland) at 661308 million. ${ }^{6}$ Based on the available literature, they suggest that road transport is probably responsible for about $50 \%$ of the economic cost of air pollution in the EU24. ${ }^{6}$

Table 1 External costs associated with health impacts in the EU due to air pollution in 2010

\begin{tabular}{|c|c|c|c|}
\hline Health and economic impact & & Pollutant & Costs CM/year \\
\hline Acute mortality (all ages) & Premature deaths & $\mathrm{O}_{3}$ & $1,531-3,679$ \\
\hline Chronic mortality (all ages) LYL median VOLY* & Life years lost & PM & $232,569-559,052$ \\
\hline Chronic mortality $(30 \mathrm{yr}+)$ deaths median VSL* & Premature deaths & PM & $413,567-842,312$ \\
\hline Infant mortality $(0-1 \mathrm{yr})$ median VSL & Premature deaths & PM & $2,990-6.090$ \\
\hline Chronic bronchitis $(27 y r+)$ & Cases & PM & 19,001 \\
\hline Bronchitis in children ( 6 to 12 years) & Cases & PM & 3,664 \\
\hline Respiratory hospital admissions (all ages) & Cases & PM & 316 \\
\hline Respiratory hospital admissions (>64) & Cases & $\mathrm{O} 3$ & 42 \\
\hline Cardiac hospital admissions ( $>18$ years) & Cases & PM & 242 \\
\hline Cardiovascular hospital admissions (>64) & Cases & $\mathrm{O}_{3}$ & 192 \\
\hline Restricted activity days (all ages) & Days & PM & 40,144 \\
\hline Asthma symptom days (children $5-19 y r$ ) & Days & PM & 474 \\
\hline Lost working days (15-64 years) & Days & PM & 15,779 \\
\hline Minor restricted activity days (all ages) & Days & $\mathrm{O}_{3}$ & 4,571 \\
\hline Core median VOLY & & & 327,691 \\
\hline Core mean VoLY & & & 657,913 \\
\hline Core median VSL & & & 505,120 \\
\hline Core mean VSL & & & 937,434 \\
\hline
\end{tabular}

* These rows represent alternative measures of the same effect on mortality, and hence are not additive. LYL, Life Years Lost; VOLY, Value of a Life Year lost; VSL, Value of a Statistical Life. VSL is derived from an individual's valuation of willingness to pay to reduce the risk of dying. European Commission $2013 .^{5}$

\section{European air pollution legislation}

International cooperation in Europe is required to reduce air pollution due to the transboundary nature of air pollution. Several legal instruments are used to promote environmentally friendly behaviour and to contribute indirectly to 
minimising air pollution. As an attempt to mandate low levels of $\mathrm{PM}_{10}$, the European Commission enacted the 2005 Clean Air Directive (Table 2). ${ }^{7}$ Since 2005, the EU limit values for $\mathrm{PM}_{10}$ is $40 \mu \mathrm{g} / \mathrm{m}^{3}$ as annual mean limit value and $50 \mu \mathrm{g} / \mathrm{m}^{3}$ as a daily limit value. However, 35 day are permitted to exceed this daily limit value each year. The target value since 2010 and limit value since 2015 is $25 \mu \mathrm{g} / \mathrm{m}^{3}$ for $\mathrm{PM}_{2.5} . \mathrm{NO}_{2}$ is limited to $40 \mu \mathrm{g} / \mathrm{m}^{3}$ each year and $200 \mu \mathrm{g} / \mathrm{m}^{3}$ in one hour.

The European Union planned to impose stricter $\mathrm{PM}_{10}$ limits starting on January 2010. The daily limit could not be exceed more than seven days annually and the yearly average could not exceed $20 \mu \mathrm{g} / \mathrm{m}^{3}$. These plans were abolished since these standards would have been difficult for many European cities. ${ }^{7}$ However, urban centres are often densely populated, making the resulting health impacts particularly significant.

Table 2 European air quality standards

\begin{tabular}{llllll}
\hline Pollutant & Concentration & $\begin{array}{l}\text { Averaging } \\
\text { period }\end{array}$ & Legal nature & $\begin{array}{l}\text { Permitted } \\
\text { exceedences } \\
\text { each year }\end{array}$ & $\begin{array}{l}\text { WHO- } \\
\text { limits }\end{array}$ \\
\hline $\mathrm{PM}_{10}$ & $50 \mu \mathrm{g} / \mathrm{m}^{3}$ & 1 day & Limit: 2005 & 35 & $50 \mu \mathrm{g} / \mathrm{m}^{3}$ \\
& $40 \mu \mathrm{g} / \mathrm{m}^{3}$ & 1 year & Limit: 2005 & $\mathrm{n} / \mathrm{a}$ & $20 \mu \mathrm{g} / \mathrm{m}^{3}$ \\
$\mathrm{PM}_{2.5}$ & $/$ & 1 day & $/$ & $/$ & $25 \mu \mathrm{g} / \mathrm{m}^{3}$ \\
& $25 \mu \mathrm{g} / \mathrm{m}^{3}$ & 1 year & Target: 2010 & 18 & $10 \mu \mathrm{g} / \mathrm{m}^{3}$ \\
& & & Limit: 2015 & & $200 \mu \mathrm{g} / \mathrm{m}^{3}$ \\
$\mathrm{NO}_{2}$ & $200 \mu \mathrm{g} / \mathrm{m}^{3}$ & 1 hour & Limit: 2010 & $\mathrm{n} / \mathrm{a}$ & $\mathrm{n} / \mathrm{a}$ \\
& $40 \mu \mathrm{g} / \mathrm{m}^{3}$ & 1 year & Limit: 2010 & $40 \mu \mathrm{g} / \mathrm{m}^{3}$ \\
\hline
\end{tabular}

In the European Union between $21 \%$ and $30 \%$ of the urban population is exposed to $\mathrm{PM}_{10}$ concentrations above the EU daily limit value of $50 \mu \mathrm{g} / \mu \mathrm{m}^{2}$ in 2010 and 2012 (Table 3)..$^{8}$ While even $64-83 \%$ of the population was exposed to concentrations exceeding the WHO guideline values of $\mathrm{PM}_{10}$. The stricter limits of the WHO are showed in table 1. Even compliance of the EU measures would not solve outstanding health problems since the standards were set as interim objectives rather than at a level recommended by the WHO. 
Table 3 Percentage of the urban population in the EU-28 exposed to air pollutant concentrations above EU and WHO reference levels (2010-2012).

\begin{tabular}{|c|c|c|c|c|}
\hline Pollutant & EU reference value & $\begin{array}{c}\text { Exposure estimate } \\
(\%)\end{array}$ & WHO AQG & $\begin{array}{c}\text { Exposure estimate } \\
(\%)\end{array}$ \\
\hline $\mathrm{PM}_{25}$ & Year (25) & $10-14$ & Year (10) & 91-93 \\
\hline $\mathrm{PM}_{10}$ & Day (50) & $21-30$ & Year $(20)$ & $64-83$ \\
\hline $\mathrm{O}_{3}$ & 8-hour (120) & 14-17 & 8-hour (100) & $95-98$ \\
\hline BaP & Year $\left(1 \mathrm{ng} / \mathrm{m}^{3}\right)$ & 24-28 & Year $\left(0.12 \mathrm{ng} / \mathrm{m}^{3}\right)$ & $85-89$ \\
\hline $\mathrm{NO}_{2}$ & Year (40) & $8-13$ & Year (40) & $8-13$ \\
\hline $\mathrm{SO}_{2}$ & Day (125) & $<1$ & Day (20) & $36-43$ \\
\hline $\mathrm{CO}$ & 8-hour (10) & $<2$ & 8-hour (10) & $<2$ \\
\hline $\mathrm{Pb}$ & Year $(0.5)$ & $<1$ & Year $(0.5)$ & $<1$ \\
\hline Benzene & Year (5) & $<1$ & Year (1.7) & $10-12$ \\
\hline
\end{tabular}

Colour coding: $\quad<5 \%$

Source: European Environment Agency. ${ }^{\gamma}$

\section{Health implications of exposure in the early-life environment}

Our research highlights the importance of reducing air pollution in the early-life environment especially in vulnerable populations such as twins who are already at risk for reduced birth weight and small for gestational age. The $\mathrm{PM}_{10}$ exposure during the third trimester $\left(30.3 \mu \mathrm{g} / \mathrm{m}^{3}\right)$ in our population was lower than the EU limit value $\left(40 \mu \mathrm{g} / \mathrm{m}^{3}\right)$ but 1.5 times higher than the annual limit value of WHO $\left(20 \mu \mathrm{g} / \mathrm{m}^{3}\right)$. If a reduction of $10 \mu \mathrm{g} / \mathrm{m}^{3}$ would be achieved this is likely to prevent $40 \%$ of the twins who were small for gestational age in moderate to late preterm births. Our data shows that the WHO limit value is highly relevant for the protection of the public health.

In addition, our twin studies prove the importance of the environment on biomarkers of ageing in placental tissue. This shows that these biomarkers are not genetically determined but can be improved by reducing traffic and increasing greenness. This suggest that a policy to reduce air pollution and traffic exposure will not only reduce mortality and disease development but also may improve healthy ageing.

Moreover, we show that surrounding greenness in early-life is associated with a lower blood pressure in adulthood. After additional adjustment for residential greenness exposure in adulthood, an interquartile increase $(+20 \%)$ in residential greenness exposure in early-life (5000 m radius) was associated with a 2.42 
$\mathrm{mmHg}(95 \% \mathrm{CI}:-4.7$ to $-0.2 ; \mathrm{p}=0.04)$ decrease in adult night systolic blood pressure. Previous studies have shown that a small reduction in blood pressure at the population level could have major impacts in reducing morbidity and mortality. ${ }^{9}$ Even, a $2 \mathrm{~mm} \mathrm{Hg}$ lower systolic blood pressure at the population level would result in an $10 \%$ overall reduction in mortality due to stroke mortality and about 7\% lower mortality from ischemic heart disease or other vascular causes in middle age. ${ }^{9}$ This shows that an increase of residential greenness exposure of $20 \%$ in the early-life environment could have an major effect on health on the population level.

\section{Conclusions}

Our research indicates the importance of the early-life environment. Especially pregnant women and young children need to avoid high concentrations of air pollution. This may be done by informing mothers and future mothers about the possible implications of air pollution and traffic exposure on their child's health. However, our results also show that action on an international level is need to reduce the current EU limit values for $\mathrm{PM}_{10}\left(40 \mu \mathrm{g} / \mathrm{m}^{3}\right)$ to the $20 \mu \mathrm{g} / \mathrm{m}^{3}$ level recommended by the WHO. The size of the economic cost burden caused by air pollution suggest that the benefits of reducing these cost could easily outweigh the costs of investment in more ambitious programmes. 


\section{References}

1. Brunekreef B and Holgate ST. Air pollution and health. Lancet. 2002;360:1233-1242.

2. Nawrot TS, Perez L, Kunzli N, Munters E and Nemery B. Public health importance of triggers of myocardial infarction: a comparative risk assessment. Lancet. 2011;377:732-740.

3. Katsouyanni K, Touloumi G, Spix C, Schwartz J, Balducci F, Medina S, et al. Short-term effects of ambient sulphur dioxide and particulate matter on mortality in 12 European cities: results from time series data from the APHEA project. Air Pollution and Health: a European Approach. BMJ (Clinical research ed). 1997;314:1658-63.

4. WHO. Burden of disease from Ambient Air Pollution for 2012. 2014.

5. $\quad$ EC. European Commission Staff Working Document. 2013.

6. OECD. The cost of air pollution. Health impacts of road transport. OECD Publishing. 2014.

7. Wolff HP, L. Trends in Clean Air Legislation in Europe: Particulate Matter and Low Emission Zones. Review of Environmental Economics and Policy. 2010;4:293-308.

8. $\quad$ EEA. Air Quality in Europe - 2014. 2014.

9. Lewington S, Clarke R, Qizilbash N, Peto R and Collins R. Age-specific relevance of usual blood pressure to vascular mortality: a meta-analysis of individual data for one million adults in 61 prospective studies. Lancet. 2002;360:1903-13. 


\section{Dankwoord}


Dit doctoraat is tot stand gekomen dankzij de hulp en steun van velen. Hen wil ik dan ook graag bedanken. Een speciaal woord van dank gaat uit naar mijn promotor aan de Universiteit van Hasselt Prof. dr. Tim Nawrot en mijn promotor aan de Universiteit van Maastricht Prof. dr. Maurice Zeegers.

Tim, jou wil ik eerst en vooral bedanken omdat je mij de kans hebt gegeven om dit doctoraat te starten. Tijdens mijn masteropleiding was het mijn droom om aan een universiteit verder onderzoek te kunnen verrichten. Verder wil ik je bedanken voor alles wat ik van jou heb geleerd tijdens mijn doctoraat. Het was fijn om samen te werken met iemand met zoveel passie en gedrevenheid.

Maurice, bedankt om mijn onderzoek te verrijken. Het verbinden van een unieke tweelingenstudie aan de kennis omtrent omgevingsfactoren heeft een uniek en interessant onderzoek gecreëerd. Bedankt, voor jouw inspirerende visie, het nalezen van mijn teksten en jouw belangrijke rol binnen dit onderzoek.

Graag zou ik ook alle leden van de beoordelingscommissie willen bedanken voor de evaluatie van mijn proefschrift en hun bereidheid om zitting te nemen in de jury bij mijn verdediging. I would like to thank all the members of the jury for the evaluation of my PhD thesis and their willingness to be a member of the review committee: voorzitter Prof. dr. J.J. van Os en de leden Prof. dr. S. Entringer, Prof. dr. W. Gyselaers, Prof. dr. H. Peeters en Prof. dr. C. Thijs.

Catherine, Marij en Evert, jullie wil ik bedanken om me te introduceren in de wereld van de tweelingen en voor de fijne tijd tijdens het congres in Boedapest. Catherine en Marij, bedankt om een deel van jullie kennis met mij te delen. Iedereen die zich inzet voor het Oost-Vlaamse Meerlingenregister, bedankt voor jullie enorme toewijding en jarenlange harde werk. Dit maakt het in stand houden van dit unieke cohort mogelijk.

Mijn collega's aan de Universiteit van Hasselt wil ik bedanken voor de onvergetelijke congressen maar ook voor de aangename werksfeer. Iedereen staat altijd klaar om een ander te helpen en niets is te veel gevraagd. 
Ik wil mijn bureaugenoten bedanken Bianca, Eline en Michal. Bianca, bedankt voor de uitwisseling van tips over de recepten van Pascale Naessens. Eline, het was heel fijn om een bureau te mogen delen met jou en ik denk dat iedereen van ons kantoor het daar mee eens is. Op al onze vragen heb je steeds het juiste antwoord of het juiste advies klaar. Michal, bedankt om een deel van jouw enorme kennis met mij te delen. Eén van de vele voorbeelden is programmeren en zonder jou was dit niet mogelijk geweest.

Nelly, jou heb ik beter leren kennen tijdens de vele leuke gesprekken in het labo in het eerste jaar van ons doctoraat. Bram, jij zorgt altijd voor de sfeer in de groep en dat er naast al het harde werk ook nog tijd is voor wat ontspanning. Diana, veel plezier in Barcelona, we gaan jouw organisatievaardigheden zeker missen bij het plannen van het volgende congres. Maria, bedankt voor de vele interessante gespreken over onze gemeenschappelijke hobby yoga. Dries en Bianca, de yogasessie op het strand in Barcelona ga ik niet snel vergeten. Laat me maar weten wanneer 'Yoga aan de Demer' start, ik zal er zijn. Ellen (en natuurlijk ook de andere twee statisticussen), bedankt voor jullie vele hulp bij mijn analyses. Narjes, op de congressen leerden we jou van een heel andere kant kennen en waren we blij dat jouw sterkste drankje een alcoholvrije cocktail was maar vooral bedankt voor alle hulp bij de Limburgse Tweeling Studie. Martien, bedankt voor de leuke tijd die we samen hebben doorgebracht zowel in als buiten het labo. Tijdens je junior stage heb ik je veel in het labo kunnen leren maar de rollen zijn ondertussen omgedraaid. Tijs, Annette en Leen bedankt voor jullie bijdrage aan de groepssfeer.

Verder ben ik Harry en alle post-docs - Michelle, Karen, Kevin en Janneke dankbaar voor hun adviezen. Karen, bedankt voor de goede begeleiding van de hele onderzoeksgroep en vooral bedankt voor al je hulp bij de opstart van de Limburgse Tweeling Studie. Harry, bedankt voor al je Masterclasses. Jouw kritische blik en commentaren op mijn teksten hebben niet alleen geleid tot een verbetering van de teksten maar hebben me ook geleerd om het in de toekomst nog beter te doen. 
Mijn collega's aan de Universiteit van Maastricht wil ik bedanken voor alle gezellige etentjes, de leuke uitstapjes en de fijne gesprekken. Hanneke, bedankt voor je hulp bij het regelen en plannen van mijn promotie.

Prof. em. dr. Yves Guisez, bedankt om mij tijdens mijn masterthesis aan de Universiteit van Antwerpen te leren dat ik met hard werken alles kan bereiken wat ik wil.

Linde, jou ben ik heel erg dankbaar. Dankzij jou hulp heb ik geleerd om op een goede manier om te gaan met mijn dyslexie. Ik besef heel goed dat ik zonder jouw hulp nooit in staat zou zijn geweest om deze thesis te schrijven.

Familie en schoonfamilie, bedankt voor jullie interesse in mijn onderzoek. Vrienden en vriendinnen, bedankt voor jullie steun en advies op de mindere momenten en jullie enthousiasme als er iets te vieren was.

Mijn paranimfen, Hannelore en mijn zus Michelle. Hannelore, wij hebben samen al een lange weg afgelegd. Een weg die lang geleden begon in de lagere school en dan nu allebei aan het doctoreren. We hebben ook letterlijk een lange weg afgelegd naar alle uithoeken van de wereld. Tijdens die vele reizen heb ik vooral van jou geleerd dat ik me minder zorgen moet maken en dat alles altijd goed komt. Mijn keuze om jouw als paranimf te vragen was dan ook snel gemaakt.

Michelle en Koen, jullie wil ik vooral bedanken om van 2015 het beste jaar ooit te maken. Het afronden van een doctoraat in combinatie met een verbouwing maakte van 2015 mijn drukste en zwaarste jaar ooit maar ik zal vooral van 2015 de geboorte van mijn neefje Mathis onthouden.

Mama en papa, ik wil jullie bedanken om er altijd voor mij te zijn en om altijd in mij te blijven geloven. Jullie hebben mij geleerd om altijd optimistisch te zijn en jullie hebben er voor gezorgd dat ik altijd de juiste beslissing heb genomen betreffende studiekeuzes. Papa, bedankt om op ieder moment klaar te staan voor je twee dochters. Mama, mijn belangrijkste eigenschappen als onderzoeker heb ik duidelijk van jou, mijn nieuwsgierigheid en mijn doorzettingsvermogen. 
Thomas, jou wil ik vooral bedanken voor de goede organisatie van de verbouwingen en het nemen van belangrijke beslissingen. Dit gaf me de kans om verder te schrijven aan mijn thesis zonder mij zorgen te maken om het huis. Bedankt ook voor het plannen van alle reizen die we de afgelopen jaren hebben gemaakt en hopelijk kunnen we snel uitkijken naar een volgende reis. 


\section{Curriculum Vitae}


Esmée Bijnens was born in March 1988 in Genk, Belgium. She studied Biology at Hasselt University. In 2009 she graduated at Hasselt University and the same year she started the master Cel- en Systeembiologie at Antwerp University. This gave her the opportunity to specialize in molecular biology. During her masterthesis she studied post-transcriptional modifications in histones in Brassica napus. She graduated in 2011 with distinction at Antwerp University. Subsequently she started a Joint PhD at the Centre for Environmental Sciences at Hasselt University (Prof. Dr. Tim Nawrot) and the Department of Complex Genetics at Maastricht University (Prof. Dr. Maurice Zeegers). In 2012, she followed a post-academic course "Modelling of Environmental Exposures Using GIS" at Imperial College, London. In 2014, she joined the International Workshop on Statistical Genetic Methods for Human Complex Traits at the University of Colorado.

During her PhD she investigated the effect of traffic related exposure in early-life in twins. Important traffic parameters can be calculated via a Geographic Information System (GIS). She applied this geo-information system in on one of the world largest longitudinal prospective twin cohort. The East Flanders Prospective Twin Survey (EFPTS), a Belgian population based register which started in 1964, offers the opportunity to follow up twins from birth to adulthood. Environmental influences on the intrauterine environment may not only effect fetal growth but also may predispose offspring to increased risk of clinical outcomes later in life. 


\section{List of publications}




\section{List of publications}

\section{Articles in peer-reviewed journals}

1. Saenen ND, Plusquin M, Bijnens E, Janssen BG, Gyselaers W, Cox B, Fierens F, Molenberghs G, Penders J, Vrijens K, De Boever P and Nawrot TS. In Utero Fine Particulate Air Pollution and Placental Expression of Genes in the Brain-Derived Neurotrophic Factor Signaling Pathway: An ENVIRONAGE Birth Cohort Study. Environ Health Perspect. 2015; 123 : 834-40.

2. Bijnens E, Zeegers MP, Gielen $M$, Kicinski $M$, Hageman $G j$, Pachen $D$, Derom C, Vlietinck R and Nawrot TS. Lower placental telomere length may be attributed to maternal residential traffic exposure; a twin stud. Environ int. 2015; 79: 1-7.

3. Kicinski M, Vermeir G, Van Larebeke N, Den Hond E, Schoeters G, Bruckers L, Sioen I, Bijnens E, Roels HA, Baeyens W, Viaene MK and Nawrot TS. Neurobehavioral performance in adolescents is inversely associated with traffic exposure. Environ int. 2015; 75:136-43.

4. Goeminne PC, Bijnens E, Nemery B, Nawrot TS and Bupont L. Impact of traffic related air pollution indicators of non-cystic fibrosis bronchiectasis mortality: a cohort analysis. Respir Res. 2014; 15:108.

5. Bijnens E, Pieter N, Dewitte H, Cox B, Janssen BG, Saenen N, Dons E, Zeegers MP, Int Panis L and Nawrot TS. Host and environmental predictors of exhaled breath temperature in the elderly. BMC Public Health. 2013; 13:1226. 


\section{Conference material}

1. Bijnens E, Zeegers MP, Loos R, Gielen M, Vlietinck R, Derom $C$ and Nawrot TS. Blood pressure in young adulthood and residential exposure of traffic and greenness in the early-life environment of twins. ISEE Early Career Researchers Conference on Environmental Epidemiology; Utrecht; The Netherlands; 2015.

2. Bijnens E, Nawrot TS, Derom C, Janssen BG, Vrijens K, Vlietinck R, Gielen M and Zeegers MP, Maurice P. Maternal residential greenness and traffic indicators in association with alterations in placental mitochondrial DNA content in twins ISEE Early Career Researchers Conference on Environmental Epidemiology; Utrecht; The Netherlands; 2015.

3. Bijnens E, Derom C, Gielen M, Winckelmans E, Fierens F, Vlietinck R, Zeegers MP and Nawrot TS. Fetal growth restriction and exposure to particulate air pollution in the early-life environment of twins. Healthy Living Conference; Maastricht; The Netherlands; 2015.

4. Bijnens E, Zeegers MP, Gielen M, Kicinski M, Hageman Gj, Pachen D, Derom C, Vlietinck R and Nawrot TS. Lower placental telomere length may be attributed to maternal residential traffic exposure; a twin study. Healthy Living Conference; Maastricht; The Netherlands; 2015.

5. Bijnens E, Derom C, Gielen M, Winckelmans E, Fierens F, Vlietinck R, Zeegers MP and Nawrot TS. Strong associations between particulate air pollution and fetal growth in twins. World Congress on Twin Pregnancy and International Society of Twin Studies (ISTS); 2014; Budapest, Hungary, 2014.

6. Bijnens E, Zeegers MP, Gielen M, Kicinski M, Hageman Gj, Pachen D, Derom C, Vlietinck R and Nawrot TS. Lower placental telomere length may be attributed to maternal residential traffic exposure; a twin study. ISTS Twins 2014; Budapest, Hungary, 2014. 
7. Bijnens E, Zeegers MP, Gielen M, Kicinski M, Hageman Gj, Pachen D, Derom C, Vlietinck R and Nawrot TS. Lower placental telomere length may be attributed to maternal residential traffic exposure; a twin study. ISEE Young Researchers Conference on Environmental Epidemiology; Barcelona; Spain; 2014.

8. Bijnens E, Pieter N, Dewitte H, Cox B, Janssen BG, Saenen N, Dons E, Zeegers MP, Int Panis L and Nawrot TS. Host and environmental predictors of exhaled breath temperature in the elderly. Environment and Health: Bridging South, North, East and West; Basel, Switzerland; 2013. 